\title{
Effects of sediment upon benthic macroinvertebrates in forested northern Appalachian streams
}

\author{
Michael Douglas Kaller \\ West Virginia University
}

Follow this and additional works at: https://researchrepository.wvu.edu/etd

\section{Recommended Citation}

Kaller, Michael Douglas, "Effects of sediment upon benthic macroinvertebrates in forested northern Appalachian streams" (2001). Graduate Theses, Dissertations, and Problem Reports. 1256.

https://researchrepository.wvu.edu/etd/1256

This Thesis is protected by copyright and/or related rights. It has been brought to you by the The Research Repository @ WVU with permission from the rights-holder(s). You are free to use this Thesis in any way that is permitted by the copyright and related rights legislation that applies to your use. For other uses you must obtain permission from the rights-holder(s) directly, unless additional rights are indicated by a Creative Commons license in the record and/ or on the work itself. This Thesis has been accepted for inclusion in WVU Graduate Theses, Dissertations, and Problem Reports collection by an authorized administrator of The Research Repository @ WVU. For more information, please contact researchrepository@mail.wvu.edu. 
Effects of sediment upon benthic macroinvertebrates in forested northern Appalachian streams

By

Michael D. Kaller

\begin{abstract}
A THESIS
Submitted to the College of Agriculture, Forestry, and Consumer Sciences at

West Virginia University

in partial fulfillment of the requirements

for the degree of

Master of Science

in

Wildlife and Fisheries Resources
\end{abstract}

Department of Wildlife and Fisheries Resources

Dr. Kyle J. Hartman, Ph. D., Chair

Dr. Ted R. Angradi, Ph. D.

Dr. Patricia M. Mazik, Ph. D.

Dr. J. Todd Petty, PH.D.

Morgantown, West Virginia

2001 


\section{Abstract \\ Effects of sediment upon benthic macroinvertebrates in forested northern Appalachian streams}

\section{Michael D. Kaller}

Excess fine sediment negatively influences the fauna of North American streams. With the current emphasis on multiple-use forests, the question is not whether fine sediment is detrimental, but what is the threshold of fine sediment that is tolerable?

To determine a threshold tolerance of fine sediment, a two-part project investigated the influence of fine sediment upon benthic macroinvertebrates. The first part encompassed two experiments in sediment manipulation in 1999 and 2000. The experiments tested benthic macroinvertebrate metric sensitivity to a range of fine sediment treatments. The second part involved four seasonal surveys of seven streams to determine the threshold amount of fine sediment.

The fine sediment experiments revealed EPT taxa richness and \% climber to be sensitive to increasing proportions of fine sediment. The stream surveys identified significant declines $(p<0.0001)$ in EPT taxa richness occurring when fine sediment exceeded approximately $1 \%$ of the substrate composition. 


\section{Dedication}

"Men almost always walk in paths beaten by others and act by imitation.

Though he cannot hold strictly to the ways of others or match the ability of those he imitates, a prudent man must always tread the path of great men and imitate those who have excelled, so that even if his ability does not match theirs, at least he will achieve some semblance of it. He should act like the prudent archer who, knowing the limitations of his bow and judging the target to be too far off, sets his aim still farther off, not to strike so distant of a mark, but rather to strike the desired target through the more ambitious aim."

- Niccolo Machiavelli, The Prince.

This thesis is dedicated to those whose paths I followed as best I could. Their insistence on the importance of education and following my interests is responsible for the success I have experienced thus far. I dedicate this to those who have seen the unfolding of my efforts: Joseph and Barbara Jones; Eileen, Douglas, and Matthew Kaller; and Joseph, Michael, and Nancy Kasprzak. I would especially like to dedicate this thesis to the memory of those who never saw this project undertaken, but were nonetheless instrumental in it happening thanks to their inspiration and faith in me: Joseph Kaller; and Charlotte and Jerome Livernois. 


\section{Acknowledgements}

Foremost, I thank my major professor, Kyle J. Hartman, for bringing me on and developing this project with me. I also thank my graduate committee, Ted Andragi, Pat Mazik, and J. Todd Petty for all of their constructive comments and guidance. In particular, I especially appreciate all the technical help and all around support from Ted Angradi who turned a good idea into, what I consider, a great project.

Numerous individuals helped in the field. Their assistance with labor as well as laughs made field work a pleasure. These individuals were: Randy Cook, Amy Patsos, Matthew Sipe, and Doug Wegman. In the lab, Tom Bassista, Randy Cook, Matt Evix, Lisa Kendall, and our pet rooster, Mr. Poopers, helped bug picking and/or kept the lab interesting. Chris Dobony, the founder of "Team Bug," taught me it was OK to stop at Order. John Sweka and William Thayne offered statistical advice. Karen Stevens and Donald Bolden (and his 6-wheeler) of the Forest Service were instrumental in surmounting physical barriers to this project. I particularly thank Janet Clayton of the W. V. DNR and Steven Harris of Clarion University for spot checking of some identifications.

Several individuals stand out in their contributions to this project. Charles Sizemore put in serious effort in the field and the lab. John Howell kept the peace in the lab. My partner in "dirt," James Hakala, kept me on pace, worked like the devil in the field, and got me out in the woods where I belonged. Finally, for helping to maintain my sanity (what little bit is left), I thank M. Kaller, S. Diekema, J. Zuck, J. Johnson, J. Kapp, K. Keller, M. Starbuck, and F. Secreto. 
Table of contents

Section

Page Number

Abstract

ii

Dedication

iii

Acknowledgements

iv

List of Tables

vi

List of Figures

$x$

Chapter 1. Introduction

1

Chapter 2. Experimental determination of benthic

40

Macroinvertebrate metric sensitivity to fine sediment in forested Appalachian streams.

Chapter 3. Effects of substrate amounts, sizes, and drought on benthic macroinvertebrate metrics in forested northern Appalachian streams.

Chapter 4. Discussion

Appendix 1. Taxonomic record.

Vitae 


\section{List of Tables}

Table

Page Number

Table 1. Functional groups of aquatic macroinvertebrates based upon trophic sources and habitat types (from

Cummins and Merritt 1996).

Table 2. The Appalachian representatives of Cummins and Merritt (1996) functional groups.

Table 3. The Appalachian representatives of macroinvertebrate habitat groups (Cummins and Merritt 1996).

Table 4. Physical and chemical characteristics of Mullenax Run.

Table 5. Significant differences between

Surber samples and ambient trays, indicating sampling artifact caused by the trays.

Table 6. Differences in metrics between ambient trays $(\%<2 \mathrm{~mm}=0.0933)$ and $10 \%$ treatment level.

Table 7. Metric response to increasing fine sediment $(<2 \mathrm{~mm})$ tested by linear regression across treatment groups. 


\section{List of Tables}

Table

Page Number

Table 8. Taxonomic differences

between 1999 and 2000 tray

experiments.

Table 9. Summary of metric responses

to in recent Appalachian studies.

Table 10. Physical habitat and water quality characteristics for 7 streams in the Monongahela National Forest.

Table 11. Water chemistry characteristics collected during storm events during 2000 in 7 streams in the Monongahela National Forest.

Table 12. Mean sediment in 7 study streams in the Monongahela National Forest.

Table 13. EPT taxa composition in the Monongahela National Forest in the fall of 1998. Genera are listed where differences in genera were found in the six streams.

Table 14. Metric responses to fine sediment in 7 streams in the Monongahela National Forest during the fall of 1999.

Table 15. EPT taxa composition in seven streams in the Monongahela National Forest in the summer of 2000. Genera are listed where differences in enera were found between the streams. 


\section{List of Tables}

Table

Page Number

Table 16. Summary of metric responses to fine sediment size class (\% less than size listed) with and without pool habitat included in analyses. A (+) or (-) next to the sediment size class indicates the direction of the response.

Table 17. Table 17. Summaries of metric responses to sediment in this and other Appalachian studies.

Table 18. Changes in substrate composition in Elleber Run from 19992000. 


\section{List of Figures}

Figure

Page Number

Figure 1. Schematic diagram of the

trophic system in spring fed streams.

Figure 2. Community change with

increasing degredation in a stream ecosystem.

Figure 3. Fine sediment treatments and

Mullenax average.

Figure 4. One of the randomizations of

manipulated and ambient treatments used in the summers of 1999 and 2000.

Figure 5. Metric responses to increasing fine sediment treatments in 1999.

Figure 6. Precipitation amounts for

Figure 8. Declines in EPT taxa richness,

Trichoptera taxa richness, and Plecoptera taxa richness in response to increasing fine sediment $<0.125 \mathrm{~mm}$ in the fall of 1998. Values are expressed in mean number of genera per sample in each stream. Error bars are $95 \%$ confidence intervals about the mean.

Figure 9. Negative relationships between EPT taxa richness and sediment less than $8 \mathrm{~mm}$ in the fall of 1999. 


\section{List of Figures}

Figure

Page Number

Figure 9. Negative relationships

115

between EPT taxa richness, Trichoptera

taxa richness, and \% collector with

increasing fine sediment less than 0.125

$\mathrm{mm}$ in riffles in the fall of 1998.

Figure 10. Positive relationships

116

between \% Baetidae of

Ephemeroptera, \% Perlodidae, and \%

scraper with increasing sediment less

than $0.125 \mathrm{~mm}$ in riffles during the fall of

1998.

Figure 11. Positive relationships

between \% Trichoptera and \%

Polycentropodidae with increasing fine sediment less than $1 \mathrm{~mm}$ in riffles during the spring of 1999.

Figure 12. The metric \% non-insect

declines with increasing sediment less

than $0.125 \mathrm{~mm}$ during the spring of 1999.

Figure 13. Positive relationships

between Plecoptera taxa richness and

Trichoptera taxa richness with increasing fine sediment less than 0.125

$\mathrm{mm}$.

Figure 14. Negative relationships

between EPT taxa richness and fine sediment $(<0.125 \mathrm{~mm}$ in Fall 1998) and (<0.25 mm in Spring 2000). 


\section{Introduction:}

Headwater streams of the northern Appalachians originate in forested areas and generally do not flow through other land cover types, such as agricultural or urban areas, until $5^{\text {th }}$ or $6^{\text {th }}$ order. The headwater and low order streams of the Appalachians typically follow the River Continuum Model outlined by Vannote et al. (1980) (Grubaugh et al. 1996). In the headwaters, allochthanous inputs, consisting mainly of leaf litter, is processed by macroinvertebrates of various trophic groups from coarse particulate organic matter (CPOM) into fine particulate organic matter (FPOM) and, finally, into dissolved organic matter (DOM) (Vannote et al. 1980; Thorp and Covich 1991;

Cummins and Merritt 1996). CPOM is considered to be particles larger than $1 \mathrm{~mm}$, FPOM is considered to be particles between $1 \mathrm{~mm}$ and $0.005 \mathrm{~mm}$, and DOM consists of particles smaller than $0.005 \mathrm{~mm}$ (Allan 1995).

Macroinvertebrates have evolved to take advantage of different sizes of CPOM and FPOM, as well as, predaceous and omnivorous lifestyles (Cummins and Merritt 1996). Insectivorous fish target herbivorous and predaceous macroinvertebrates (Allan 1995). The conversion of energy from plant biomass to macroinvertebrate biomass continues through the food web into fish biomass within these streams (Vannote et al. 1980). Furthermore, incompletely processed CPOM and FPOM may pass downstream into higher order streams providing a food source for other fish and invertebrates (Vannote et al. 1980). Benthic insect removal studies at Coweeta Hydrologic Lab found significantly lower conversion of coarse particulate organic matter (CPOM) to fine particulate organic matter (FPOM) following pesticide treatments designed to remove benthic macroinvertebrates (Swank and Crossley 1988). These studies refuted earlier 
research that suggested macroinvertebrates played a minor role in processing allochthanous inputs. Macroinvertebrates in headwater systems are major contributors to downstream particulate organic matter (POM) (Vannote et al. 1980; Swank and Crossley 1988). Any interruption in processing CPOM to FPOM may alter trophic status and community composition and function in the river network downstream.

The primary determinant of macroinvertebrate type and abundance is the nature of the stream ecosystem in which they dwell (Huryn and Wallace 1987). Mountain streams, including those in the Appalachians, originate either from groundwater springs or from precipitation runoff (Thorp and Covich 1991). The origin of the stream, whether groundwater or runoff, defines the differences in flow regimes, physiochemical characteristics, and substrate composition found among streams and rivers (Thorp and Covich 1991). Runoff driven streams are more stochastic and ephemeral in nature with extremes in physiochemical characteristics, whereas groundwater fed streams exhibit greater stability in flows and water chemistry (Thorp and Covich 1991). Within the Appalachians, most headwater streams are groundwater fed and are not runoff driven until further downstream or during storm events.

Streams, regardless of origin, have three distinct biotic: water column, benthic, and hyporheic (Thorp and Covich 1991). The water column extends from the water's surface to the bottom (Thorp and Covich 1991; Merritt and Cummins 1996). The benthos consists of the organic and inorganic substrate and the interstitial spaces between substrate particles (Thorp and Covich 1991). The benthos may extend up to $30 \mathrm{~cm}$ below the surface of the substrate (Merritt and Cummins 1996). The hyporheic zone extends below the benthos and, at times, laterally from the stream (Merritt and 
Cummins 1996). These three zones are not independent of each other, and a constant exchange of biota, dissolved metals, dissolved gases, and nutrients occurs between the three zones. (Thorp and Covich 1991; Boulton 1993; Wagner et .al. 1993).

Sediment is constantly entering and leaving stream reaches in unaltered systems in a balance determined by stream flow, and the stream's ability to transport sediment particles, that produces a substrate composition that is fairly stable within the individual stream (Leopold et al. 1964; Swanston 1991). Finer sediment particles are constantly entering streams through overland transport and exposed banks (Leopold et al. 1964). Larger sediment particles generally only enter streams during catastrophic events such as floods or when banks or hill slopes are destabilized due to erosion of the toe, or base, of the slope (Leopold et al. 1964; Swanston 1991). In unaltered streams, streamflow immediately begins to transport smaller particles out of the system and wear the larger particles into smaller particles over time (Leopold et al. 1964; Beschta and Jackson 1976; Rosenberg and Weins 1978; Swanston 1991). Disturbances in stream channel or the contributing upslope watershed alter sediment addition regimes and streamflows thus altering the transport and removal of finer sediment from the stream (Leopold et al. 1964; Beschta and Jackson 1976). In these situations, finer particles settle and intrude into the benthos in amounts greater than in undisturbed systems (Beschta and Jackson 1976). Research has indicated particles $0.2 \mathrm{~mm}$ and smaller have the greatest degree of intrusion into the substrate reducing the permeability of the benthos to stream water and blocking access to interstitial spaces in the benthos (Beschta and Jackson 1976). 
The transport of sediment within the stream channel creates two primary habitat types for macroinvertebrates. Erosional transport in fast moving, higher gradient areas removes the finer sediment particles leaving the larger cobble and gravel particles to form riffle habitat (Leopold et al. 1964; Cummins and Merritt 1996). Depositional transport in slower moving, lower gradient areas accumulates finer particles creating pool and other depositional habitat (Leopold et al. 1964). Macroinvertebrates have evolved to exploit both habitats; however, abundance and diversity of macroinvertebrates is higher in riffles than pools due to increased permeability, greater amount of interstitial space, more POM, more periphyton, higher dissolved oxygen, greater variation in velocity, and increased food delivery in the benthos in riffles over pools (Leopold et al. 1964; Pennak 1978; Thorp and Covich 1991; Cummins and Merritt 1996).

\section{Macroinvertebrate Classification Schemes}

The word "macroinvertebrate" represents a wide variety of organisms occupying a diversity of niches within the stream ecosystem. With such a diversity of roles and types of organisms, means of classification are needed to break the large category of "macroinvertebrate" into smaller groups in order to understand spatial and temporal patterns within the stream ecosystems. Several schemes have been proposed to classify the large diversity within the macroinvertebrate community. The two major schemes classify macroinvertebrates by functional groups or taxonomic groups. Functional groups may be determined without taxonomic knowledge while taxonomic 
classification allowed for greater delving into community details provided the reader understands the ecology of the taxonomic group (Karr and Chu 1999).

Macroinvertebrates may be divided into functional groups based upon their habitat choices as well as their trophic roles (Table 1). Some groups are restricted to either a lotic or lentic system while others are more ubiquitous. The following descriptions will be restricted to lotic inhabitants typical of those found in forested headwater streams. Cummins and Merritt (1996) presented the following categories of macroinvertebrates based on habitat choices. Skaters dwell upon the water's surface. Swimmers cling to the substrate and periodically swim between the patches of substrate in short bursts. Sprawlers exhibit modifications for lifestyles on vascular vegetation or on the surface of fine sediment. Climbers occupy vascular stems or detrital collections similar to those usually found in depositional areas of the stream. Clingers dwell upon the surfaces of substrate in fast moving sections of stream. Burrowers inhabit the fine sediments of streams.

Macroinvertebrates fall into several trophic roles in the stream based upon their food source. Cummins and Merrit (1996) presented a further classification dealing with predaceous and detritivorous macroinvertebrates within the system. Shredders break apart living vascular tissue, CPOM, or excavate wood within the stream and are responsible for processing CPOM into FPOM. Collectors focus their activities on processing FPOM into tissue biomass or into DOM. Collectors are sometimes further divided into gatherers and filterers depending on the size of the FPOM they consume. Scrapers, sometimes called grazers, feed upon periphyton within the stream. Since periphyton is limited by light, scraper populations are usually low in forested headwater 
streams while collector populations may be higher. Predators feed upon other macroinvertebrates and, occasionally, fish.

Macroinvertebrates are also divided taxonomically. There is considerable overlap between trophic and habitat group classification and taxonomic classification particularly at the family level. Generally, families fall into one trophic or habitat group (Cummins and Merritt 1996). For example, the families Ephemeridae (Ephemeroptera) and Perlidae (Plecoptera) are represented by the collector and predator trophic groups respectively. Ephemerids are burrowers while Perlids are clingers.

Over the years, stream ecologists have debated the level of taxonomic precision necessary to describe aquatic communities (Resh et al. 1995; Rosenberg and Resh 1996; Karr and Chu 1999). Early efforts emphasized family- level descriptions of aquatic communities while proponents of species-level identification influenced later research (Rosenberg and Resh 1996). Family level identification has again become popular for its efficiency in both cost and time (Karr and Chu 1999). However, recently a consensus has arisen to use genus-level identification when describing communities using taxonomic classifications as family-level identification fails to account for differences in habitat and trophic choices at the genus-level while species-level identification does not return enough detail to justify the time invested or possible additional error generated in identification (Resh et al. 1995; Rosenberg and Resh 1996; Karr and Chu 1999).

Macroinvertebrates also may be taxonomically separated with a simple classification of insect (Coleoptera, Ephemeroptera, Diptera, Hemiptera, Hymenoptera, Megaloptera, Lepidoptera, Odonata, Plecoptera, and Trichoptera) or non-insect 
(Annelida, Amphipoda, or Decapoda). Many studies have found this approach to be useful as habitat and resource partitioning between the insects and non-insects within a stream are reflective of different lifestyle adaptations between the two groups (Stribling et al. 1998). Insects and non-insects utilize different trophic pathways within the stream ecosystem with insects primarily exploiting plant biomass and non-insects using detritus or, to a lesser extent, plant biomass (Pennak 1978; Thorp and Covich 1991). Due to more generalist habitat selection and omnivorous trophic roles, non-insects are difficult to classify using the system described by Cummins and Merritt (1996). It is considered superior to use taxonomic classifications when dealing with non-insects (Stribling et al. 1998; Karr and Chu 1999).

\section{Non-insects}

Within the Appalachians, four major taxa of non-insects inhabit headwater streams. These taxa are Decapoda (crayfish), Amphipoda (scud), Oligochaeta (segmented worms), and Bivalvia (clams). Other taxa, such as Copepoda, Isopoda, Hirudinea (leeches), and Nematomorpha (horsehair worms), make occasional contributions to samples but are generally confined to larger lotic systems or lentic waters (Pennak 1978). Most non-insects are generalists; however, some are adapted for specific habitats (Pennak 1978).

The order Decapoda represents a generalist group of non-insects (Pennak 1978; Jezerinac et al. 1995). Decapods are omnivorous, although herbivory and detritivory exceed carnivory (Pennak 1978; Jezeriniac et al. 1995). Jezerinac et al. (1995) report one family of Decapoda, Cambaridae, is found in Appalachian headwater streams. 
Cambaridae may be found in both riffle or pool habitat within a stream, however, preference is shown for pool habitat. Cambaridae is tolerant of wide ranges of temperature, water quality, flows, and sedimentation and is limited in number only by its territorial nature

Amphipoda represents a non-insect specialist (Peckarsky et al. 1990). Amphipods are omnivorous although generally detrital or herbivoral feeders (Pennak 1978). Amphipods are not strong swimmers and prefer pools, littoral zones, or aquatic vegetation (Peckarsky et al. 1990). Freshwater amphipods are intolerant of a wide range of water quality and temperature, preferring higher $\mathrm{pH}$ to lower and cooler temperatures to warmer ones; however, their preference for aquatic vegetation makes them fairly sediment tolerant (Peckarsky et al. 1990).

Oligochaeta are considered to be generalists in terms of distribution (Pennak 1978). Most Oligochaetes in headwater systems are members of Tubificidae, Niadidae, or rarely Lumbriculidae (common earthworm) (Peckarsky et al. 1990). Oligochaetes are generally tolerant of a wide variety of stream temperatures, water qualities, and substrate types as well as exploiting feeding mechanism similar to terrestrial Annelids (Pennak 1978; Peckarsky et al. 1990). Tubificidae, in particular, are known for tolerance of low dissolved oxygen due to their very efficient respiratory system (Rosenberg and Resh 1996).

The less common Bivalvia is represented by two families, Corbiculidae and Sphaeridae, in the Appalachians (Peckarsky et al. 1990). Corbiculidae is an exotic found only in larger lotic and lentic systems while Sphaeridae is a native bivalve found in all sizes of systems including the headwaters (Peckarsky et al. 1990). Sphaeridae is 
considered to be intolerant preferring better water quality and less sedimentation (Peckarsky et al. 1990).

\section{Insects}

Insects represent a more diverse group of organisms with a greater percentage of total population numbers and biomass than non-insects in unimpaired headwater streams (Stewart and Stark 1988). Insects have exhibited the greatest adaptive radiation of all animals occupying nearly every aquatic habitat (Resh and Solem 1996). The origin of insects from primitive Arthropods is controversial and not well understood, yet it is known that two of the oldest orders, Ephemeroptera and Odonata, are found in freshwater aquatic environments. These two orders are presumed to have arisen in the Devonian period while the majority of the aquatic insects evolved in the Mississippian and Pennsylvanian periods. These ancient orders are not very different from their archaic ancestors with substantial ramifications to distribution and trophic role. With over 200 million years of evolution, it is perplexing the apparent stagnation some of the orders exhibit. However, fossils suggest this stagnation is due to selection of habitats where the insects are superior competitors to avoid selective pressures. Headwater streams with their stochastic and ephemeral nature exercise strong selective pressures that, in combination with insect specialization, have reduced the need to further evolve within the aquatic orders (Thorp and Covich 1991). Another interpretation of the evidence is that the stochastic and primitive nature of headwater systems is very similar to the conditions insects evolved from other Arthropods (Resh and Solem 1996; Wallace and Anderson 1996). It is important to consider the primitive and stagnant 
nature of the evolution of most aquatic insects as it leaves them unequipped to handle rapid changes in their environment either through rapid adaptation or utilization of sophisticated coping mechanisms. At any rate, headwater streams have representatives of ten orders of aquatic insects (McCafferty 1998).

\section{Insect Taxonomic Orders}

The aquatic insects comprise the orders Coleoptera, Diptera, Ephemeroptera, Hemiptera, Hymenoptera, Lepidoptera, Megaloptera, Odonata, Plecoptera, and Trichoptera (Merritt and Cummins 1996). Diptera, Ephemeroptera, Odonata, Plecoptera, Trichoptera, and Megaloptera are entirely aquatic while Lepidoptera, Hemiptera, and Hymenoptera are mostly terrestrial with a few aquatic species (Merritt and Cummins 1996). Coleoptera is well represented in both aquatic and terrestrial habitats (White and Brigham 1996). In most aquatic orders, insects spend their egg and larvae stages in aquatic habitats emerging to mate and disperse as adults (Merritt and Cummins 1996). Some members of Coleoptera spend their entire lives in aquatic habitats (White and Brigham 1996). The larval stages of these orders are of greatest interest in scientific study of streams because the larvae tend to be sedentary and are exposed to all of the vagaries in water quality, temperature, and substrate condition (Resh et al. 1995; Rosenberg and Resh 1996; Karr and Chu 1999).

\section{Coleoptera}

The order Coleoptera (beetles) is the largest order of insects with about 5,000 aquatic species (White and Brigham 1996). Despite their diversity, coleopterans tend to 
not be very numerous in streams (McCafferty 1998). Coleopterans can be distinguished readily from other insect groups with their hardened elytra, or wing cover, and heavy sclerotization, or armoring. These morphological adaptations to aquatic habitats are primitive compared to other orders (White and Brigham 1996). The primitive and inflexible nature of these morphological adaptations placed some limits upon the distribution of coleopterans and lessens their tolerance to temperature, substrate, and, especially, water quality. The coloepterans can be divided into three suborders, Adephaga, Myxophaga, and Polyphaga. Of these three, Adephaga and Polyphaga are of interest in headwater systems. The members of these wholly aquatic suborders are substrate dwellers, usually swimming or climbing upon the surface of the substrate. Adephagans are predaceous and Polyphagans either are FPOM-collectors or periphyton-feeders. This combination of habitat choice and feeding method generates a preference for riffle habitat among coleopterans where they can take advantage of the generally higher macroinvertebrate abundances and larger substrate particles.

\section{Diptera}

Diptera (true flies) is one of the most diverse of the aquatic insect orders with about 3,500 aquatic species in lotic habitats (McCafferty 1998). It is difficult to generalize about dipterans as they have evolved to fill nearly every possible habitat type and trophic role (Courtney et al. 1996). Diptera is a recently evolved order that has undergone explosive adaptive radiation. Dipterans are generally considered to be the most advanced order of aquatic insects featuring the most sophisticated adaptations to aquatic lifestyles. Dipterans exhibit amazing adaptations to stream habitats. Simuliidae, 
Deuterophlebiidae and Blephariceridae have specialized morphology to cling to the surfaces of the substrate in fast moving waters. Simuliidae extends a fan into the current to filter food particles while specialized attachment structures stabilize the larvae in the substrate. Blephariceridae have evolved suctorial disks while Deuterophlebiidae have complex hook structures on its fore legs. Dipterans dwell in and on the substrate as well on vascular plants. Members of diptera occupy nearly every habitat type and trophic role within a stream yielding a classification of generalist for the order in both habitat use and trophic role (Cummins and Merritt 1996). Experiments with Chironomidae reveal larval recovery after several years of drought, immersion in liquid helium, and exposure to $100^{\circ} \mathrm{C}$ (Wallace and Anderson 1996). Most dipteran taxa do not exhibit such resilience, but are considered hardy as an order. However, family and genus level analysis of dipterans reveals that, although dipterans as an order are tolerant of extremes in temperature, substrate, and water quality, specific families and genera are specialized to particular combinations of habitat, temperature, and water quality (Cummins and Merritt 1996; Karr and Chu 1999). This typically high level of tolerance offers both depositional pool and riffle habitat as options for different families and genera of Diptera.

\section{Ephemeroptera}

Ephemeroptera (mayflies) is the one of the oldest of the aquatic insect orders probably arising from even more ancient Odonates (Resh and Solem 1996). In North America, there are about 700 species of Ephemeroptera mostly restricted to lotic habits (McCafferty 1998). Ephemeroptera exhibits the most primitive morphological 
adaptations to aquatic lifestyles featuring exposed external gills (Edmunds and Waltz 1996). These primitive morphological structures are inflexible to rapid change and limit the distribution and tolerance of ephemeropterans to good water quality and limited temperature ranges (Wallace and Anderson 1996). Ephemeropterans primarily dwell upon substrate with few burrowing species (Edmunds and Waltz 1996).

Ephemeropterans have specialized morphological adaptations particular to habitat. Ephemerellidae and, especially, Heptageniidae demonstrate some degree of dorsoventral flattening with modification to claws for clinging to surfaces in fast moving water while Ephemeridae has modified claws for burrowing into fine substrate (Edmunds and Waltz 1996). Other families, such as Isonychiidae, Ameletidae, and Baetidae are adapted to a swimming lifestyle partly independent of substrate and habitat (Wallace and Anderson 1996). Herbivory and FPOM processing are the primary trophic roles of Ephemeroptera with each family usually partitioning its role into a specific part of the processing of CPOM into FPOM (Cummins and Merritt 1996). The high levels of specialization in habitat choice and trophic roles among ephemeropterans allow exploitation of both pool and riffle habitat by the order Ephemeroptera; however, the majority of ephemeropterans are better suited to the larger substrate of riffle habitat.

\section{Hemiptera}

Hemipterans (true bugs) are found in both terrestrial and aquatic environments with about 400 species either totally or partially aquatic (McCafferty 1998). Aquatic Hemiptera are the only insect with species adapted to the open ocean (Polhemus 1996). Hemipterans are never numerous in stream habitats and either dwell on 
substrate or the surface film (Polhemus 1996). Hemipterans are primarily predaceous or parasitic with few FPOM-processing genera (Polhemus 1996). Hemipterans require an abundance of other macroinvertebrates to prey upon or parasitize and are limited in number and distribution in this fashion (Rosenberg and Resh 1996). The order Hemiptera has recently evolved, and its sophisticated morphology allows a fairly wide tolerance of environmental conditions provided a prey base exists (Rosenberg and Resh 1996; Stribling et al. 1998).

\section{Hymenoptera}

Aquatic Hymenoptera (wasps) are few in number and limited in diversity (Hagen 1996). Most aquatic hymenopterans are parasitic wasps that dive into streams and lay eggs within other aquatic insects. These parasites only contribute to stream surveys during the brief period following emergence from the host before emergence from the stream.

\section{Lepidoptera}

Aquatic lepidopterans (caterpillars) are a small portion of the overall order Lepidoptera. Only 49 species spend any part of their life cycle in aquatic habitats (McCafferty 1998). Only one species of lepidoptera, Acentria nivea, spends any portion of its adult life in aquatic habitats (Lange 1996). 


\section{Megaloptera}

Megaloptera (alderflies and dobsonflies) is a small but wholly aquatic order (McCafferty 1998). The long-lived Megalopterans place an unusual twist in the typical aquatic insect lifestyle by laying eggs on land and then entering the water as larvae finally emerging as pupae back into the terrestrial environment (Evans and Neunzig 1996). Megalopterans are known for wide ranges in tolerance of environmental conditions (Cummins and Merrit 1996). Two families of Megaloptera, Corydalidae and Sialidae, are important in the Appalachians (Peckarsky et al. 1990). The families are both dwellers on the substrate and predaceous (Evans and Neunzig 1996). The major difference between the families is their tolerance ranges. Corydalidae has a narrower range of tolerance toward temperature, water quality, and habitat than Sialidae (Evans and Neunzig 1996; Stribling et al. 1998). However, when environmental conditions fall into the optimum ranges for both families the more aggressive Corydalidae is the superior competitor to Sialidae (Evans and Neunzig 1996). In view of many entomologists and stream ecologists, Corydalidae represents the consummate predator among aquatic insects (Evans and Neunzig 1996; McCafferty 1998). Overall, the Megalopteran's predaceous nature and need for large substrates on which to hunt produce an overwhelming preference for riffle habitat.

\section{Odonata}

Odonata (dragonflies and damselflies) represent the oldest order of aquatic insects where all 450 species spend the majority of their lives in aquatic systems 
(McCafferty 1998). Odonates only leave aquatic systems as adults to mate and disperse after spending several years as larvae (Westfall and Tennessen 1996). Within the order, Odonata demonstrates a tolerance of a wide range of temperatures, but not a wide range of water quality (Rosenberg and Resh 1996). Odonates have fairly uniform habitat requirements and trophic roles across the order (Westfall and Tennessen 1996). Odonates are predaceous and either burrow or dwell upon fine substrates with a few exceptions in swimming families (Westfall and Tennessen 1996). Odonates are predators but their habitat adaptations tend to limit them to pool habitat.

\section{Plecoptera}

The order Plecoptera (stoneflies) numbers some 500 species in North America (McCafferty 1998). This order is considered important to stream ecology as members of Plecoptera are not only important CPOM and FPOM processors but also predaceous (Stewart and Stark 1988). Plecopterans are sometimes the only predator in headwater systems when environmental conditions, particularly low temperature and small stream size, exclude Megaloptera, Hemiptera, and Decapoda (Stewart and Stark 1988). As with Diptera, family- and genus-level descriptions of Plecoptera yield more information about macroinvertebrate communities than order-level descriptions. The wide variety of trophic roles within Plecoptera mean a finer level of identification can produce a tremendous yield in information about a macroinvertebrate community in a stream (Stewart and Stark 1988). This is of particular importance to remember as diversity and abundance of Plecoptera is not only limited by their narrow tolerance of temperatures, habitat, and water quality but also by their available prey base (Stewart and Stark 1988; 
Cummins and Merritt 1996). Plecopterans may be found in depositional areas taking advantage of accumulations of leaf litter; however, their claws are better suited to larger substrate within riffle habitat (Wallace and Anderson 1996). Furthermore, predaceous plecopterans actively hunt among the larger substrate particles in riffles (Stewart and Stark 1988). Therefore, the majority of plecopterans within a stream are found in riffle habitats.

\section{Trichoptera}

The 1,200 species of Trichoptera (caddisflies) are a recently evolved order of insects arising from Lepidoptera (Resh and Solem 1996; McCafferty 1998). Trichoptera is second only to Diptera in terms of adaptive radiation, and their success can mostly be attributed to case-making (Wiggins 1998). Case-making is a trait shared only with one primitive lepidoteran group and allows trichopterans to modify their micro-habitat. A detailed examination of the benefits of case-making is beyond the scope of this introduction, but enhanced respiration, predator avoidance, and micro-habitat stability during stochastic flows are some of the advantages. The ability to produce silk used in case-making allows the larvae of Hydropsychidae, Philopotamidae, and Polycentropodidae to spin nets to capture FPOM from the current. Some trichopterans, such as Rhyacophilidae, do not use cases as a case would interfere with their predaceous lifestyle. The incredible diversity of trophic roles and habitat choices makes generalizations concerning the order Trichoptera difficult, yet some characteristics are shared by all members of Trichoptera. trichopterans are typically temperature and water quality intolerant with a few exceptions, particularly Hydropsychidae (Stribling et 
al. 1998; Wiggins 1998). Case-making trichopterans require exposed rock or woody surfaces for case attachment, thus they are fine sediment intolerant preferring riffle habitat. Free-living trichopterans are less particular about habitat type. Trichopterans occupy trophic roles from CPOM and FPOM processors to predators (Cummins and Merritt 1996). Due to their remarkable diversity, trichopterans are present in nearly every aquatic system.

\section{Stream Trophic Cascades}

The interaction of these various groups of macroinvertebrates within streams is the subject of much research. However, the basic dynamics of the trophic interactions within the spring fed or runoff driven streams has some consensus among researchers. The main energy input in both types of streams is an allochthanous source from plant biomass entering stream primarily as leaf litter (Vannote et al. 1980; Murphy and Meehan 1991; Allan 1995). Cummins and Merritt (1996) outlined the general flow of energy within a stream begins with macroinvertebrates breaking the whole leaf into digestible particles (Figure 1). These macroinvertebrates are the shredder group (from the functional group classification systems) and consist of the orders Amphipoda, Decapoda, Coleoptera, Plecoptera, and Trichoptera; in particular, the families Curculionidae, Gammaridae, Limnephilidae, Leucritidae, Peltoperlidae, and Pteronarycidae. These macroinvertebrates generate more particles than they can consume losing some downstream in the process. They also pass partially digested particles as frass. The larger particles swept away by the current are downstream sources of CPOM while frass makes up a major component of downstream FPOM. Not 
unsurprisingly, other macroinvertebrates collect these particles for further breakdown. These macroinvertebrates are in the collector functional group and are gatherers or filterers based on particle size. The macroinvertebrates taxa involved at this stage are in the orders Bivalvia, Coleoptera, Diptera, Ephemeroptera, Plecoptera, and Trichoptera; specifically the families Baetidae, Chironomidae, Dixidae, Elmidae, Ephemeridae, Ephemerellidae, Hydropsychidae, Isonychiidae, Leptophlebiidae, Nemouridae, Philopotamidae, Simuliidae, Siphlonuridae, Sphaeridae, Taeniopterygidae, and Tipulidae. Since these streams exhibit some degree of flow stability, an alternate pathway of plant energy may exist based on periphyton. Periphyton is exploited by macroinvertebrates in the scraper functional group consisting of taxa in the order Amphipoda, Coleoptera, Ephemeroptera, and Trichoptera; particularly the families Ameletidae, Baetiscidae, Gammaridae, Glossosomatidae, Helicopsychidae, Heptageniidae, Psephenidae, Psychomyiidae, and Uenoidae. Other macroinvertebrates predators prey upon the Shredders, Scrapers, and Collectors. The Predator taxa in streams are the orders Coleoptera, Decapoda, Diptera, Hemiptera, Megaloptera, Odonata, Plecoptera, and Trichoptera; especially the families Aeshnidae, Athericidae, Chloroperlidae, Coenagrionidae, Cordulegasteridae, Corydalidae, Dytiscidae, Gerridae, Gomphidae, Gyrinidae, Hydrophilidae, Macroveliidae, Perlidae, Perlodidae, Polycentropodidae, Rhyacophilidae, and Veliidae. Fish, if present, prey upon all levels of the macroinvertebrate-based trophic cascade within the stream (Kreuger and Waters 1983; Stewart and Stark 1988). Incompletely processed CPOM and FPOM pass downstream to provide an additional nutrient and energy base for downstream ecosystems (Vannote et al. 1980). Another, often overlooked, energy 
pathway originates in the detritus. Macroinvertebrates also function as detrivores particularly Oligochaeta and Decapoda (Pennak 1978; Thorp and Covich 1991).

\section{Biomonitoring}

Traditionally, stream ecology was viewed in terms of trophic processing for game fish with macroinvertebrates only important in terms of their contributions to fish and downstream systems (Kreuger and Waters 1983). Over the years, this view began to change with a simultaneous realization that the two major macroinvertebrate classification schemes could be synthesized for a greater understanding of community dynamics (Karr and Chu 1999) (Tables 2, 3). Although the use of macroinvertebrates as indicators was recognized as early as 1908 with the use of Tubificid worms to detect the impact of sewage outflows, it was not until the early 1980's when the use of aquatic macroinvertebrates as indicators of water quality and disturbance began to receive attention (Rosenberg and Resh 1996; Karr and Chu 1999). This concept of biomonitoring grew out of the recognition of the high degree of specialization of aquatic macroinvertebrates--especially insects. This high degree of specialization may be exploited if an understanding of the specific environmental requirements is known for a taxon. The presence, absence, or changes in number of a taxon reflect the presence, absence, or changes in the taxon's specific environmental criteria. Furthermore, since functional groups consider macroinvertebrates beyond single taxon, they can be integrated into analyses to investigate community function. Assessment of community 
structure may be performed by examining the richness and diversity of taxa as well as the relative compositional proportion of each taxon within the community.

The presence, absence, or change in specific community structure is also reflective of changes in environmental conditions. In the interest of comparison between studies, a host of metrics, or measures, of richness, diversity, and proportion have been developed. Most proponents of biomonitoring advocate the use of region specific subsets of the entire list of metrics (Stribling et al. 1998). Karr and Chu (1999) further advocate creation of subsets of metrics for each region based upon the dynamics of the region involved. The discipline of biomonitoring has grown tremendously over the last two decades using fish, periphyton, and amphibians as well as macroinvertebrates in various approaches (Karr and Chu 1999).

Stream biomonitoring relies on a thorough understanding of the specific habitat requirements of macroinvertebrates (Rosenberg and Resh 1996). A shortcoming of biomonitoring is that most of the relationships between organism and environmental condition were established through empirical observation (Karr and Chu 1999). Many have questioned whether the organism is there due to selection of environmental condition or whether the organisms would be there regardless (Karr and Chu 1999). Few of these relationships have been tested in manipulative studies where macroinvertebrate response to various conditions may be quantified and described in detail (Karr and Chu 1999). This lack of information from manipulative studies combined with great disparity in research techniques produces often confusing and sometimes contradictory results when applied as a quick and efficient method to assess environmental condition (Fore et al. 1996; Rosenberg and Resh 1996; Karr and Chu 
1999). Only studies that thoroughly and accurately describe collection methodology and analytical technique generate useful and relevant biomonitoring assessments (Karr and Chu 1999). Yet, the incredible efficiency and ever-improving nature of biomonitoring propel it into the forefront of ecological research (Resh et al. 1995; Karr and Chu 1999).

Biomonitoring also may be applied to detect and evaluate the macroinvertebrate response to perturbations in the ecosystem whether anthropogenic or natural in origin (Resh et al. 1995; Rosenberg and Resh 1996; Stribling et al. 1998; Karr and Chu 1999). Taxa diversity, abundance, and community structure may be investigated following a perturbation. The relationships between taxa and community structures to specific environmental criteria may be used to describe the subsequent environmental conditions following disturbance. Reliance on empirically derived relationships has allowed some studies to evaluate perturbation without a priori sampling or reference sites (Karr and Chu 1999). One advantage of using biomonitoring to detect the results of perturbation is the aquatic community and taxa reflect the harshest conditions resulting from the perturbation for some time after the actual event or events occurred (Karr and Chu 1999). Aquatic macroinvertebrate taxa and communities following a perturbation consist of only the hardiest macroinvertebrates capable of withstand the most extreme environmental conditions resulting from the perturbation. The lag time before recolonization takes place from dispersal offers a chance to examine the perturbation's effects some time after it occurs (Stribling et al. 1998; Karr and Chu 1999). However, the conclusions drawn from studies following perturbation are still 
limited by the circular nature of the empirical evidence of the relationships between taxa, community, and environmental condition.

A general consensus exists as to a pattern of community change and taxa replacement in streams (Peckarsky et al. 1990; Waters 1995; Karr and Chu 1999) (Figure 2). The classic pattern of community change from unpolluted and unimpaired waters to highly impacted systems involves a shift from a community dominated by the insect orders Ephemeroptera, Plecoptera, Trichoptera, Megaloptera, and the crustacean Amphipoda to reduced Ephemeroptera, Plecoptera, and Trichoptera community and increased insect orders Coleoptera and Odonata and increased crustacean Decapoda populations in moderately impacted systems (Peckarsky et al. 1990; Rosenberg and Resh 1996; Karr and Chu 1999). In highly impacted systems, the insect order Diptera dominates with increased crustacean Isopoda (Peckarsky et al. 1990; Rosenberg and Resh 1996; Karr and Chu 1999). In the most impaired systems, insect orders completely disappear leaving the benthos to be occupied by the Annelid Oligochaeta (Peckarsky et al. 1990; Rosenberg and Resh 1996; Karr and Chu 1999). In rare instances, even Annelids may abandon the benthos if perturbation becomes too extreme (Rosenberg and Wiens 1978). These shifts markedly change CPOM to FPOM conversion and subsequent trophic status as shredding invertebrates are replaced and other energy pathways are favored.

\section{Sedimentation}

Sedimentation is one environmental factor known to cause macroinvertebrate community shifts in streams (Tebo 1955, Luedtke and Brusven 1976; Rosenberg and 
Resh 1978; Angradi 1999). Sediment in Appalachian streams is a result of natural geology and land use practices both past and present (Furniss et al. 1991; Harding et al. 1998). Excess sediment bed loads within streams are a result of early $20^{\text {th }}$ century and recent logging activities as well as the existing and abandoned road network (Furniss et al. 1991). Agricultural inputs exist on a limited basis in Appalachian streams (Harding et al. 1998). Logging contributes sediment of a variety of sizes while roads produce sediment particles of smaller sizes (Bilby et al. 1989; Chamberlin et al. 1991; Constantini et al. 1999). Bilby et al. (1989) found that the size and type of particles roads contribute varied based upon surface materials and grade of the road. Steeper roads contributed coarser particles to runoff while flatter roads contributed finer particles (Bilby et al. 1989). In a study in southeastern Washington, the rate and amount of sediment production was related to road traffic with the majority of particles produced by roads smaller than $0.004 \mathrm{~mm}$ in diameter (Bilby et al. 1989). Furthermore, Bilby et al. (1989) found $34 \%$ of the roads contributed directly into first and second order headwater streams. These smaller streams retained a higher proportion of finer particles than larger streams that had the power to cleanse themselves (Bilby et al. 1989). Constantini et al. (1999) examined road runoff in southeastern Australia where differences in sediment contribution between graveled and unfinished roads were tested with simulated rainfall events. Graveled surfaces were found to contribute far less sediment than unfinished road surfaces (Constantini et al. 1999). The majority of particles produced were less than $0.02 \mathrm{~mm}$ in size with concentrations of up to $8 \mathrm{~g} / \mathrm{L}$ collected in road runoff (Constantini et al. 1999). Despite the common problems of 
roads delivering fine sediment particles that are retained in streams, little peer-reviewed literature exists on the subject.

\section{Sediment effects on macroinvertebrates}

The literature concerning sediment's effects on macroinvertebrates has been recently reviewed by Waters (1995). In macroinvertebrate literature, fine sediment is considered particles less than $2 \mathrm{~mm}$ in size (Waters 1995). Angradi (1999) lists numerous studies on the effects of fine sediment upon macroinvertebrate colonization of introduced substrates, non-manipulative sediment impact studies, and influences on macroinvertebrate behavior. Most studies reveal fine sediment to cause a change from a riffle/cobble community of taxa to a sand/depositional community due to fine sediment intrusion between and coating of larger substrate particles (Sandine 1974; Waters 1995; Angradi 1999). The way in which sediment affects this change is two-fold. Sediment intrusion reduces available habitat space while coating of the substrate interferes with periphyton grazing and detrital processing (Rier and King 1996; Vuori and Joensuu 1996).

Several studies are of interest in examining sedimentation within the Appalachians. The classic paper concerning sedimentation and benthic macroinvertebrates is an examination of siltation following logging at the Coweeta Experimental Forest by Tebo (1955). Tebo (1955) found logging increased the proportion of inorganic sand and silt within the stream resulting in lower abundances of macroinvertebrates. The lower abundances were attributed to a lack of food in inorganic silt and the unstable nature of the sand substrate. Furthermore, Tebo (1955) 
found the unstable sand substrate to be subject to loss during flooding causing the associated macroinvertebrate community to be swept downstream in the process.

In northern Idaho, Luedtke and Brusven (1976) examined the effects of sand accumulation on benthic and drifting macroinvertebrates. They found that while sand was not a barrier to drifting insects, it was not colonized by the drift. Areas of sand accumulation acted as barriers to dispersal by benthic macroinvertebrates who were unable to crawl or burrow through the sand due to its unstable nature. This created isolated regions of cobble and gravel with high macroinvertebrate abundances separated by these areas of sandy accumulation. Since mating dispersal flights are typically of short distance, limitations to genetic diversity may occur if the distances between isolated macroinvertebrate populations become too great. Extreme cases of isolation may lead to extirpation through limited food resources for predators and genetic bottlenecks.

In the Northwest Territories, Rosenberg and Weins (1978) conducted an experimental fine sediment addition. Sediment additions caused immediate sediment avoidance by the sediment sensitive orders of Ephemeroptera and Plecoptera as well as sensitive dipterans such as Simuliidae. As the sediment settled within the substrate, even tolerant macroinvertebrates such as Oligochaeta eventually disappeared.

In an Indiana stream, Lamberti and Berg (1995) suggested community functional group changes may have been due to sedimentation. In areas of sedimentation, they found a $292 \%$ increase in gatherers while observing an $83 \%$ decrease in filterers in comparison to reference sites. They believe this reflected an interruption in CPOM processing due to sedimentation possibly at the shredder stage. 
In a small, forested stream, Vouri and Joensuu (1996) reported decreased Shredders in the community following increased sedimentation from logging supporting the observations of Lamberti and Berg (1995). A loss of filterers, particularly netspinning Trichopterans (such as the usually tolerant Hydropsychidae), also was noted. Vouri and Joensuu (1996) speculated the loss of shredders and filterers was due to a combination of fine sediment coating the substrate, covering $\mathrm{CPOM}$, and causing physical stress on the macroinvertebrates. Further reductions of filterers (also observed by Lamberti and Berg (1995)), specifically net-spinning trichopterans, may have been caused by fine sediment accumulating in the trichopteran's net reducing food availability and an inability to adhere to the substrate due to sediment coating the surface.

In the northern Appalachians, Angradi (1999) examined fine sediment effects upon macroinvertebrates and tested the reliability and sensitivity of metrics in the detection of these effects. This study combined a survey of 15 streams with a sediment manipulation experiment. The choice of manipulating the proportion of fine sediment less than $2 \mathrm{~mm}$ in size was determined by previous research at the Fernow experimental forest. Angradi (1999) found three metrics, EPT (Ephemeroptera, Plecoptera, and Trichoptera) taxa richness, \% Orthocladiinae (Diptera: Chironomidae), and \% Chironominae (Diptera: Chironomidae) to respond to fine sediment in both the stream survey and field experiment. The field experiment reduced some confounding environmental variables found in the field survey while revealing Ephemeroptera, Plecoptera, and Trichoptera decline in diversity relative to sediment-specialists when sedimentation levels become excessive. The response of these metrics in both the field 
survey and experiment indicated they were reliable and sensitive metrics for sediment assessment.

Fine sediment's effects upon aquatic ecosystems are not universally negative. Some fine sediment is important to aquatic ecosystems as habitat for particular groups of invertebrates (Pennak 1978; Murphy and Meehan 1991; Thorp and Covich 1991). In larger lotic ecosystems, fine sediment particles in interstitial spaces provide surfaces for the development of microbial populations important in the processing of dissolved organic carbon (DOC) into fine organic carbon (FOC) (Fiebig and Marxen 1992). Yet, even in stream and river systems where microbes are important to organic matter processing, excess amounts of fine sediment have negative consequences to macroinvertebrates (Brunke and Gonser 1999). Brunke and Gosner (1999) reported the strongest predictor of invertebrate density was the ratio of particulate organic carbon to total fine sediment particles. As fine inorganic particles increased, the ratio of organic carbon to total fine sediment particles decreased leading to a decrease in invertebrate density. Therefore, it was not the presence of fine sediment particles, but excess amounts, that had negative effects upon invertebrate density.

One of the most insidious influences in the history of stream fisheries has been the deleterious influence of the turn of the century logging practices. More recently, sediment from soil surface disturbance and roads has become a major concern for aquatic habitats. Gardner (1979) reported increases of sediment inputs into rivers by as much as 770 times following road construction in a previously roadless area. Anecdotal observations of substrate-macroinvertebrate relationships appeared in the early $20^{\text {th }}$ century; however, the earliest, rigorous scientific investigations began with 
Tebo (1955) in Coweeta and continue today (Pennak 1978; Rosenberg and Resh 1996). Many studies have linked declines in benthic macroinvertebrate abundances or changes in community composition to increases in sediment load and decreases in substrate particle size (Swank and Crossley 1988; Richards and Bacon 1994; Waters 1995; Grubaugh et al. 1996; Angradi 1999).

The previously cited studies describe the negative effects of sedimentation, propose mechanisms to explain the negative consequences, and foreshadow long-term ecological consequences of sedimentation. However, activities producing sediment in streams are not going to cease in the near future. Therefore, interest has grown in understanding the mechanisms that cause macroinvertebrate community change, generating predictive models of the macroinvertebrate changes, applying biomonitoring techniques specifically for sedimentation, and identifying when sedimentation becomes excessive (Lamberti and Berg 1995; Angradi 1999). The question is no longer whether sedimentation is deleterious to stream macroinvertebrates, but today, with multiple-use forests, the question is, "what is the threshold of sedimentation that can be tolerated"? This study is designed to identify and quantify at what level of sedimentation do community changes and declines in densities occur. Furthermore, due to its experimental component, this study contributes to the testing necessary to apply biomonitoring techniques to sedimentation to identify the most relevant metrics for sediment assessment. Multiple uses of forested lands will not end any time in the near future; thus, it is pertinent to answer in a timely fashion, "How much dirt don't hurt?" to provide forest managers with the knowledge and tools to understand the implications of and monitor the effects of forest management practices. 


\section{Literature Cited.}

Allan, J. D. 1995. Stream Ecology: Structure and function of running waters. Chapman and Hill. New York, New York.

Angradi, T. R. 1999. Fine sediment and macroinvertebrate assemblages in Appalachian streams: a field experiment with biomonitoring applications. J. N. Am. Benthol. Soc. 18:43-65.

Beschta, R. L. and W. L. Jackson. 1976. The intrusion of fine sediments into a stable gravel bed. J. Fish. Res. Board. Can. 36:204-210.

Bilby, R. E., Sullivan, K., and S. H. Duncan. 1989. The generation and fate of roadsurface sediment in forested watersheds in southwestern Washington (USA). Forest Science 35:453-468.

Boulton, A. J. 1993. Stream ecology and surface-hyporheic exchange: Implications, techniques, and limitations. Australian Journal of Marine and Freshwater Research 44:553-564.

Brunke, M. and T. Gosner. 1999. Hyporheic invertebrates - the clinal nature of interstitial communities structured by hydrological exchange and environmental gradients. J. N. Am. Benthol. Soc. 18:344-362.

Chamberlin, T. W., Harr, R. D., and F. H. Everest. 1991. Timber harvesting, silviculture, and watershed processes. American Fisheries Society Special Publication 19:181-204.

Constantini, A., Loch, R. J., Connolly, R. D., and R. Garthe. 1999. Sediment generation from forest roads: Bed and eroded sediment size distributions, and runoff management strategies. Australian Journal of Soil Research 37:947-964.

Courtney, G. W., Teskey, H. J., Merritt, R. W., and B. A. Foote. 1996. Aquatic Diptera: Part one. Larvae of aquatic Diptera. Pages 484-548. In An Introduction to the Aquatic Insects of North America ( $3^{\text {rd }}$ ed.) Merritt, R. W. and K. W. Cummins, Eds. Kendall/Hunt Publishing Company. Dubuque, lowa.

Cummins, K. W. and R. W. Merritt. 1996. Ecology and distribution of aquatic insects. Pages 74-86. In An Introduction to the Aquatic Insects of North America ( $3^{\text {rd }}$ ed). Merritt, R. W. and K. W. Cummins, Eds. Kendall/Hunt Publishing Company. Dubuque, lowa. 
Edmunds, G. F. and R. D. Waltz. 1996. Ephemeroptera. Pages 126-163. In An Introduction to the Aquatic Insects of North America ( ${ }^{\text {rd }}$ ed.) Merritt, R. W. and K. W. Cummins, Eds. Kendall/Hunt Publishing Company. Dubuque, lowa.

Evans, E. D. and H. H. Neunzig. 1996. Megaloptera and Aquatic Neuroptera. Pages 298-308. In An Introduction to the Aquatic Insects of North America ( $3^{\text {rd }}$ ed.) Merritt, $R$. W. and K. W. Cummins, Eds. Kendall/Hunt Publishing Company. Dubuque, lowa.

Furniss, M. J., Roelofs, T. D., and C. S. Yee. 1991. Road construction and maintenance. American Fisheries Society Special Publication 19:297-323.

Fiebig, D. M. and J. Marxsen. 1992. Immobilization and mineralization of dissolved free amino acids by stream-bed biofilms. Freshwater Biology 28:129-140.

Fore, L. S., Karr, J. R., and R. W. Wisseman. 1996. Assessing invertebrate responses to human actvities: evaluating alternative approaches. J. N. Am. Benthol. Soc. 15:212231.

Gardner, R. B. 1979. Some environmental and economic effects of alternative forest road designs. Transactions of the ASAE 22:63-68.

Grubaugh, J. W., Wallace, J. B., and E. S. Houston. 1996. Longitudinal changes of macroinvertebrate communities along an Appalachian stream continuum. Can. J. Fish. Aquat. Sci. 53:896-909.

Hagen, K. S. 1996. Aquatic Hymenoptera. Pages 474-483. In An Introduction to the Aquatic Insects of North America ( $3^{\text {rd }}$ ed.) Merritt, R. W. and K. W. Cummins, Eds. Kendall/Hunt Publishing Company. Dubuque, lowa.

Harding, J. S., Benfield, E. F., Bolstad, P. V., Helfman, G. S., and E. B. D. Jones III. 1998. Stream biodiversity: the ghost of land use past. Proc. Nat. Acad. Sci. 95:1484314847.

Huryn, A. D. and J. B. Wallace. 1987. Local geomorphology as a determinant of macrofaunal production in a mountain stream. Ecology 68:1932-1942.

Jezerinac, R. F., Stocker, G. W., and D. C. Tarter. 1995. The crayfishes (Decapoda: Cambaridae) of West Virginia. Bulletin of the Ohio Biological Survey 10:1-193.

Karr, J. R. and E. W. Chu. 1999. Restoring life in running waters: Better biological monitoring. Island Press. Washington, D. C.

Kreuger, C. C. and T. F. Waters. 1983. Annual production of macroinvertebrates in three streams of different water quality. Ecology 64: 840-850. 
Lamberti, G. A. and M. Berg. 1995. Invertebrates and other benthic features as indicators of environmental change in Juday Creek, Indiana. Natural Areas Journal 15:249-258.

Lange, W. H. 1996. Aquatic and semiaquatic Lepidoptera. Pages 387-398. In An Introduction to the Aquatic Insects of North America ( ${ }^{\text {rd }}$ ed.) Merritt, R. W. and K. W. Cummins, Eds. Kendall/Hunt Publishing Company. Dubuque, lowa.

Leopold, L. B., Wolman, M. G., and J. P. Miller. 1964. Fluvial processes in geomorphology. Dover Publications. Mineola, New York.

Luedtke, R. J. and M. A. Brusven. 1976. Effects of sand sedimentation on colonization of stream insects. J. Fish. Res. Board. Can. 33:1881-1886.

McCafferty, P. W. 1998. Aquatic Entomology: The fisherman's and ecologist's illustrated guide to insects and their relatives. Jones and Bartlett Publishers. Sudbury, Massachusetts.

Merritt, R. W. and K. W. Cummins. 1996. Introduction. Pages 1-4. In An Introduction to the Aquatic Insects of North America ( $3^{\text {rd }}$ ed.) Merritt, R. W. and K. W. Cummins, Eds. Kendall/Hunt Publishing Company. Dubuque, lowa.

Merritt, R. W. and K. W. Cummins. 1996. An Introduction to the Aquatic Insects of North America ( $3^{\text {rd }}$ ed $)$ Kendall/Hunt Publishing Company. Dubuque, lowa.

Murphy, M. L. and W. R. Meehan. 1991. Stream ecosystems. In Influences of forest and rangeland management on salmonids and their habitats. Meehan, W. R., ed. Special Publication 19, American Fisheries Society. Bethseda, Maryland.

Peckarsky, B. L., Faissinet, P. R., Penton, M. A., and D. J. Conklin, Jr. 1990. Freshwater macroinvertebrates of the Northeastern United States. Cornell University Press. Ithaca, New York.

Pennak, R. W. 1989. Freshwater Invertebrates of the United States: Protozoa to Mollusca. John Wiley and Sons, Inc. New York, New York.

Polehmus, J. T. 1996. Aquatic and semi-aquatic Hemiptera. Pages 267-297. In An Introduction to the Aquatic Insects of North America ( ${ }^{\text {rd }}$ ed.) Merritt, R. W. and K. W. Cummins, Eds. Kendall/Hunt Publishing Company. Dubuque, lowa.

Resh, V. H., Norris, R. H., and M. T. Barbour. 1995. Design and implementation of rapid assessment approaches for water resource monitoring using benthic macroinvertebrates. Australian Journal of Ecology 20:108-121.

Resh, V. H. and J. O. Solem. 1996. Phylogenetic relationships and evolutionary adaptations of aquatic insects. Pages 96-107. In An Introduction to the Aquatic Insects 
of North America ( $3^{\text {rd }}$ ed.) Merritt, R. W. and K. W. Cummins, Eds. Kendall/Hunt Publishing Company. Dubuque, lowa.

Rier, S. T. and D. K. King. 1996. Effects of inorganic sedimentation and riparian clearing on benthic community metabolism in an agriculturally-disturbed system. Hydrobiologia 339:111-121.

Richards, C. and K. L. Bacon. 1994. Influence of fine sediment on macroinvertebrate colonization of surface and hyporheic stream substrates. Great Basin Naturalist 54:106113.

Rosenberg, D. M. and V.H. Resh. 1996. Use of aquatic insects in biomonitoring. Pages 87-97. In An Introduction to the Aquatic Insects of North America ( $3^{\text {rd }}$ ed.) Merritt, R. W. and K. W. Cummins, Eds. Kendall/Hunt Publishing Company. Dubuque, lowa.

Rosenberg, D. M., and A. P. Wiens. 1978. Effects of sediment addition on macroinvertebrates in a northern Canadian river. Water Research 12:753-761.

Sandine, M. E. 1974. Natural and simulated insect-substrate relationships in Idaho Batholith streams. University of Idaho. M.S. thesis.

Stewart, K. W., and B. P. Stark. 1988. Nymphs of North American stonefly genera (Plecoptera). Entomological Society of America. College Park, Maryland.

Stribling, J. B., Jessup, B. K., and J. S. White. 1998. Development of a Benthic Index of Biotic Integrity for Maryland Streams. Chesapeake Bay and Watershed Programs Monitoring and Non-tidal Assessment. CBWP-MANTA-EA-98-3.

Swank, W.T., and D. A. Crossley, Jr. 1988. Forest Ecology and Hydrology at Coweeta. Ecological Studies 66.

Swanston, D. N. 1991. Natural processes. American Fisheries Society Special Publication 19:139-179.

Tebo, L. B. 1955. Effect of siltation, resulting from improper logging, on bottom fauna of a small trout stream in the Appalachains. Progressive Fish-Culturist 17:64-70.

Thorp, J. H. and A. P. Covich. 1991. An overview of freshwater habitats. Pages 17-36. In Ecology and Classification of North American Freshwater Invertebrates. Thorp, J. H. and A. P. Covich, Eds. Academic Press, Inc. San Diego, California.

Thorp, J. H. and A. P. Covich. 1991. Ecology and Classification of North American Freshwater Invertebrates. Academic Press, Inc. San Diego, California.

Vannote, R. L., Minshall, G. W., Cummins, K. W., Sedell, J.R., and C. E. Cushing. 1980. The river continuum concept. Can. J. Fish. Aquat. Sci. 45:1123-1144. 
Vouri, K. and I. Joensuu. 1996. Impact of forest drainage on the macroinvertebrates of a small boreal headwater stream: Do buffer zones protect lotic biodiversity? Biological Conservation 77:87-95.

Wagner, R. Schmidt, H. H., and J. Marxen. 1993. The hyporheic habitat of the Breitenbach, spatial structure and physiochemical conditions as a basis for benthic life. Limnologica 23:285-294.

Wallace, J. B. and N. H. Anderson. 1996. Habitat, life history, and behavioral adaptations of aquatic insects. Pages 41-73. In An Introduction to the Aquatic Insects of North America ( $3^{\text {rd }}$ ed.) Merritt, R. W. and K. W. Cummins, Eds. Kendall/Hunt Publishing Company. Dubuque, lowa.

Waters, T. F. 1995. Sediment in streams: sources, biological effects, and control. American Fisheries Society Monograph 7. American Fisheries Society. Bethseda, Maryland.

Westfall, M. F. and K. J. Tennessen. 1996. Odonata. Pages 164-211. In An Introduction to the Aquatic Insects of North America ( $3^{\text {rd }}$ ed.) Merritt, R. W. and K. W. Cummins, Eds. Kendall/Hunt Publishing Company. Dubuque, lowa.

White, D. S. and W. U. Brigham. 1996. Aquatic Coleoptera. Pages 399-473. In An Introduction to the Aquatic Insects of North America ( ${ }^{\text {rd }}$ ed.) Merritt, R. W. and K. W. Cummins, Eds. Kendall/Hunt Publishing Company. Dubuque, lowa.

Wiggins, G. B. 1998. Larvae of the North American caddisfly genera $\left(2^{\text {nd }}\right.$ ed $)$. University of Toronto Press. Toronto, Ontario. 
Table 1. Functional groups of aquatic macroinvertebrates based upon trophic sources and habitat types (from Cummins and Merritt 1996).

\section{Functional Group Habitat type}

Climber

Vascular hydrophytes or detrital debris

Clinger

Surface and interstitial spaces of the substrate

Skater

Surface of the water

Swimmer

Water column

Burrowers

Fine sediment (usually in pools)

Trophic source

Collector

Filterer

Gatherer

Predator

Shredder

Scraper(Grazer)
Suspended FPOM

Deposited FPOM

Macroinvertebrates or fish

Living vascular tissue

Decomposing CPOM

Wood

Periphyton 
Table 2. The Appalachian representatives of Cummins and Merritt (1996) functional trophic groups.

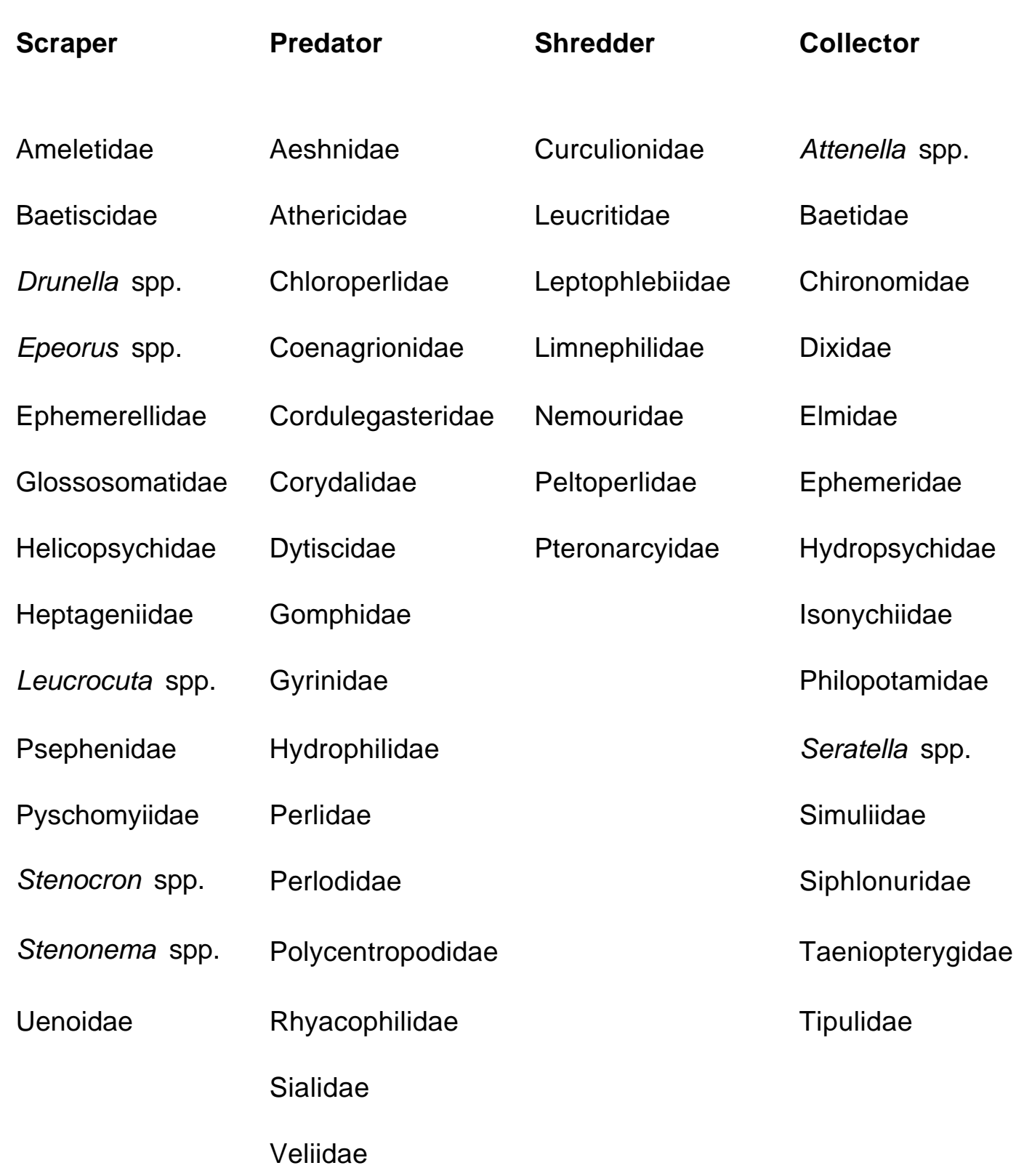


Table 3. The Appalachian representatives of macroinvertebrate habitat groups (Cummins and Merritt 1996).

\begin{tabular}{|c|c|c|}
\hline Burrower & Climber & Clinger \\
\hline Athericidae & Corydalidae & Baetiscidae \\
\hline Chironomidae & Curculionidae & Chloroperlidae \\
\hline Corydalidae & Dytiscidae & Ephemerellidae \\
\hline Ephemeridae & Elmidae & Glossosomatidae \\
\hline Gomphidae & Gyrinidae & Helicopsychidae \\
\hline Polymitarcyidae & Pteronarcyidae & Heptageniidae. \\
\hline Sialidae & Siphlonuridae & Hydrophilidae \\
\hline \multirow[t]{3}{*}{ Tipulidae } & Taeniopterygidae & Hydropsychidae \\
\hline & & Leucritidae \\
\hline & & Limnephilidae \\
\hline \multirow[t]{2}{*}{ Sprawler } & Swimmer & Nemouridae \\
\hline & & Peltoperlidae \\
\hline Aeshnidae & Ameletidae & Perlidae \\
\hline Coenagrionidae & Baetidae & Perlidae \\
\hline \multirow[t]{8}{*}{ Peltoperlidae } & Dixidae & Perlodidae \\
\hline & Gyrinidae & Philopotamidae \\
\hline & Isonychiidae & Polycentropodidae \\
\hline & Leptophlebiidae & Psephenidae \\
\hline & & Pyschomyiidae \\
\hline & & Rhyacophilidae \\
\hline & & Simuliidae \\
\hline & & Uenoidae \\
\hline
\end{tabular}




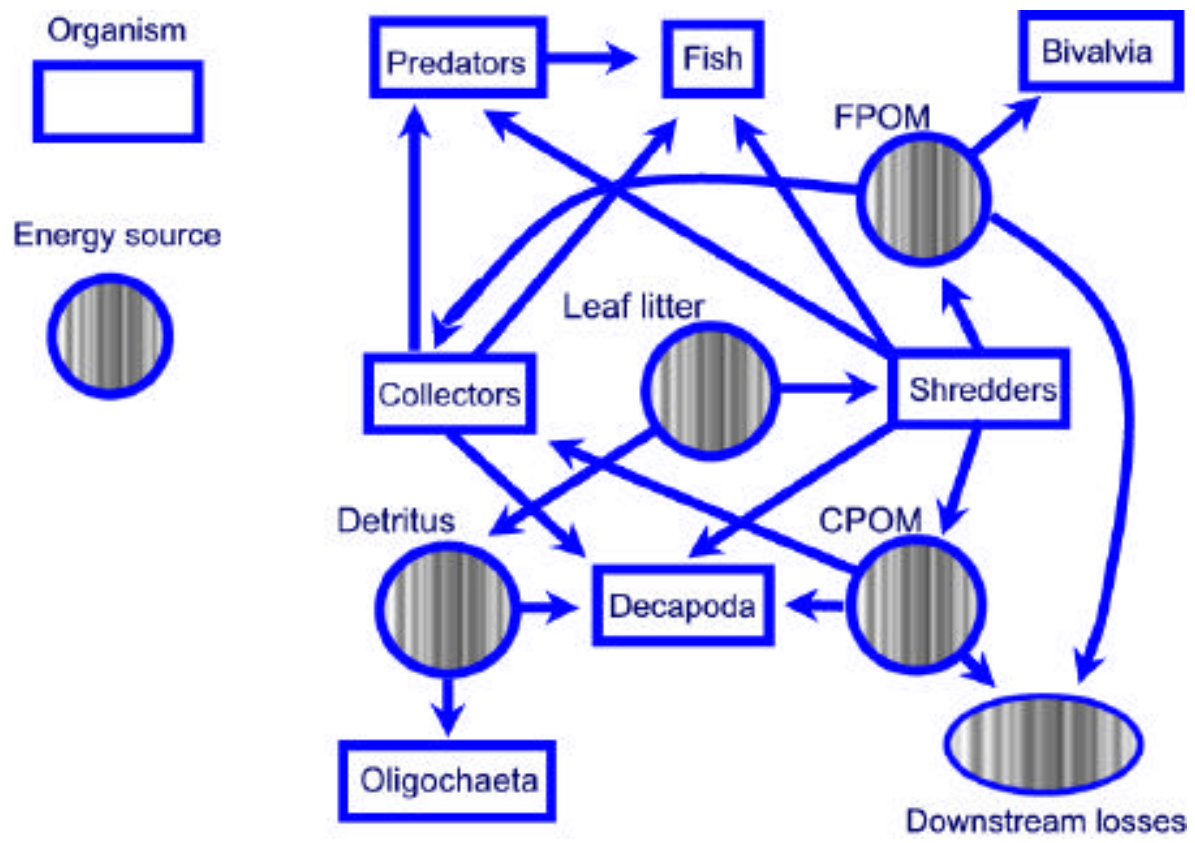

Figure 1. Schematic diagram of the trophic system in a headwater stream. 


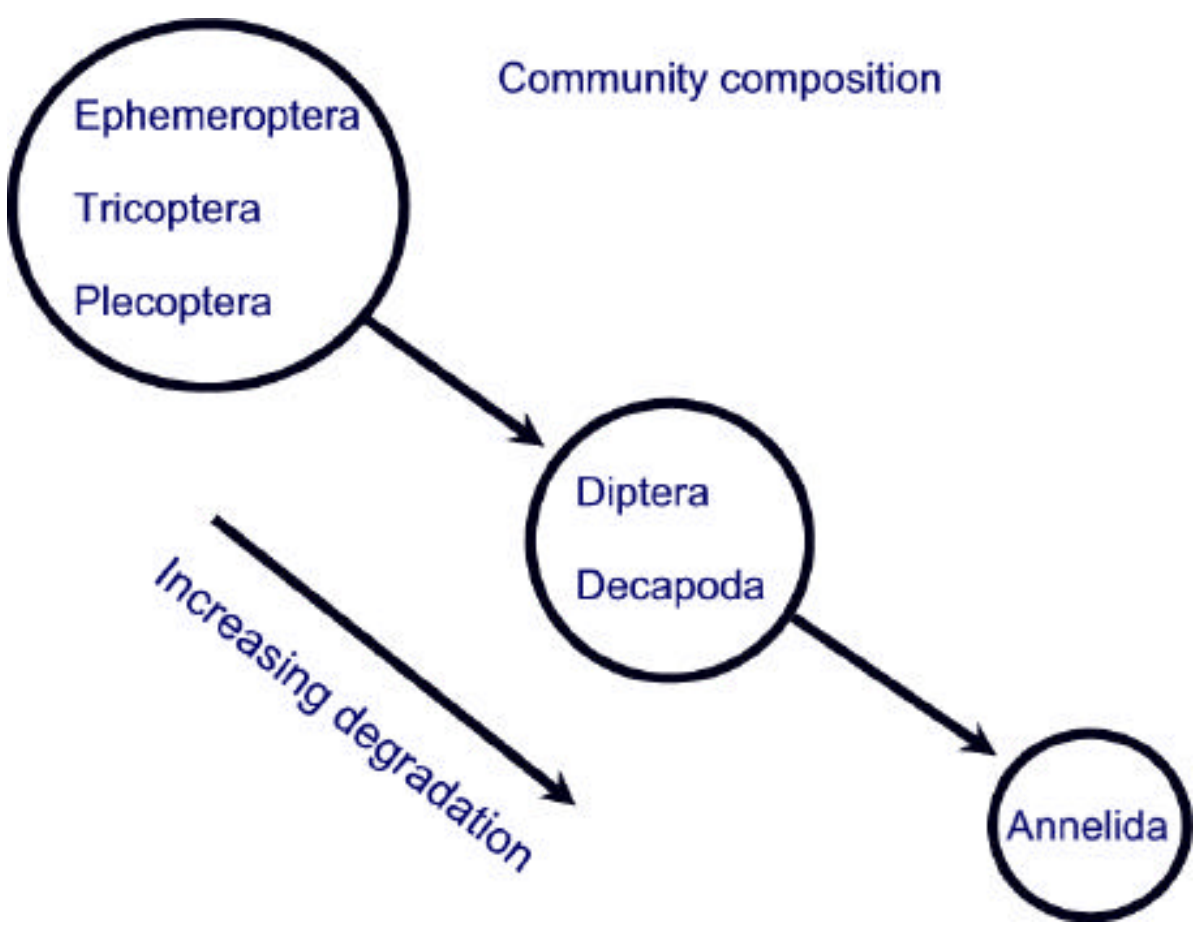

Figure 2. Community change with increasing degradation in a stream ecosystem. Circles represent relative overall biomass. 


\title{
Experimental determination of benthic macroinvertebrate metric sensitivity to fine sediment in forested Appalachian streams
}

\author{
Michael D. Kaller and Kyle J. Hartman
}

Division of Forestry, West Virginia University, Box 6125, Morgantown, WV 26505

Ted R. Angradi

U.S. Environmental Protection Agency, 999 18 $8^{\text {th }}$ St., Ste. 500, Denver, CO 80202

Abstract. Sedimentation in Appalachian streams is often elevated above ambient levels by forest management practices and the legacies of past land use. We conducted two field experiments in Mullenax Run, Pocahontas County, WV during the summers of 1999 and 2000 to investigate the sensitivity of benthic macroinvertebrate metrics to fine sediment. Substrate composition of fine sediment $(<2 \mathrm{~mm})$ was manipulated from 0$40 \%$ in $10 \%$ increments in $0.3 \mathrm{~m}^{2}$ circular trays. These trays were arrayed in two sections of Mullenax Run, a second order stream, with five stations of eight trays in each section in 1999 (80 trays total) and six stations of eight trays in each section in 2000 (96 trays total). The trays were allowed to colonize for 5 weeks in each year. In 1999, EPT taxa richness $\left(r^{2}=0.144, p=0.0031\right)$ was negatively related to increasing fine sediment while $\%$ climber $\left(r^{2}=0.217, p=0.0019\right)$ was positively related to increasing fine sediment. In 2000, relics of the drought of late summer and fall 1999 may have obscured relationships between fine sediment and benthic macroinvertebrate metrics in the experiment. Of the metrics responding to fine sediment manipulation, EPT taxa richness appears to be the most reliable metric for use in monitoring sedimentation in forested northern Appalachian streams. 
Keywords: Appalachians, benthic macroinvertebrates, drought, headwater streams, roads, sediment, substrate

\section{Introduction}

One of the most damaging influences on North American stream fisheries has been the deleterious influence of early $20^{\text {th }}$ century logging practices. More recently, sediment from soil disturbance and roads have become a major concern for aquatic habitats (Furniss et al. 1991). Gardner (1979) reported increases of sediment inputs by as much as 770 times following road construction in a previously roadless area. Many studies have examined the relationship between soil disturbance and stream fauna in the Appalachians beginning with studies at Coweeta Hydrologic Lab by Tebo (1955) and continuing today. These studies, and others worldwide, have linked declines in benthic macroinvertebrate densities or changes in community structure to fine sediment load and particle size (Swift 1988; Quinn and Hickey 1990; Richards and Bacon 1994; Waters 1995; Grubaugh et al. 1996; Vouri and Joensuu 1996; Angradi 1999).

In the Appalachians, modern logging practices and application of Best Management Practices (BMPs), such as Streamside Management Zones (SMZs), have reduced sediment inputs from logging in the Monongahela National Forest (Kochenderfer et al. 1997). However, the legacy of past land use still influences many Appalachian watersheds, whether from remnant road networks from past logging, or from past mountainside farming (Furniss et al. 1991; Harding et al. 1998). Road networks present a serious sedimentation threat as many roads receive traffic at levels and types unforeseen during construction and as road maintenance backlogs worsen (Stewart 1999). Yet, National Forests maintain a commitment to access and multiple 
uses (Clark and Gibbons 1991; Furniss et al. 1991; Stewart 1999). Therefore, it is of great interest in forest management to determine an efficient and cost-effective method of monitoring sedimentation in streams.

Quantification of sedimentation levels can be a time consuming and costly process (Grost et al. 1991; McMahon et al. 1996). The response patterns of benthic macroinvertebrate metrics have be used to identify the source of impairment to a stream (Resh et al. 1995; Rosenberg and Resh 1996; Karr and Chu 1999). Unfortunately, many metrics were initially used to identify streams where non-point source pollution occurs (Karr and Chu 1999). The suitability of these metrics to identify a particular pollution source requires extensive testing of the sensitivity of the metric to the pollution source in question (Karr and Chu 1999; Angradi 1999).

Tests of sensitivity or tolerance of macroinvertebrate taxa, and therefore, metrics based upon those taxa has been conducted for other perturbations and natural phenomenon, such as acidity in the Appalachians (Rosemond et al. 1992). Knowledge of sensitivity to acidity has been used to detect community response to perturbation or, in one West Virginian example, mitigation of acidity through limestone additions (Clayton and Menendez 1996). Similar lists of sensitive taxa, and thus, metrics, could be generated specifically to evaluate sedimentation. Therefore, there is a need to further test the sensitivity of benthic metrics to sedimentation for their use in monitoring streams.

This study tests metric sensitivity to sedimentation in Appalachian streams to provide a set of monitoring metrics by identifying metrics sensitive to fine sediment. Furthermore, this study also investigates temporal influences on the relationships 
between macroinvertebrates and fine sediment. Monitoring environmental disturbances with benthic macroinvertebrates is considered to be reliable and cost-effective (Karr and Chu 1999). Modern forest management emphasizing multiple uses of public land should include stream monitoring of aquatic habitat to prevent the consequences of resource extraction from overwhelming the interests of other users (Meehan 1991). With a set of sensitive metrics available, informed decisions concerning forest management practices can be made in regard to their effects on aquatic systems.

\section{Study Sites}

The field experiment was conducted in Mullenax Run, a second order tributary of the East Fork of the Greenbrier River, in the Monongahela National Forest in east central West Virginia. Physical habitat and water chemistry data were collected in 1999 and 2000 (Table 1). Sample sites in Mullenax Run were in the first $2 \mathrm{~km}$ upstream of the confluence with the East Fork of the Greenbrier River (N38 ${ }^{\circ} 37.3$, W79 41.1 ). Watershed vegetation consisted of second growth hardwoods and patches of loblolly pine (Pinus teada) of approximately $60-70$ years old. The underlying geology of the watershed is sedimentary shale of the Hampshire Group.

\section{Methods}

Field experimentation

In the summers of 1999 and 2000, trays with known sediment composition were placed into Mullenax Run to examine macroinvertebrate colonization of sediment levels. A second experiment was performed in 2000 due to concerns over declining flow that 
occurred during the 1999 experiment. Fine sediment (<2 mm diameter) composition within the trays was manipulated from $0 \%$ to $40 \%$ in increments of $10 \%$ similar to the method described by Angradi (1999) (Figure 1). Treatment levels were selected to provide a broad range of treatments that encompassed $(0 \%, 10 \%, 20 \%$, and $30 \%)$ and exceeded (40\%) the range of fine sediment typically observed by Angradi and Vinson (1996) in nearby streams. The manipulations were based upon mean proportions of each sediment size as determined by weight using the Wentworth scale from 6 riffle samples taken by grain scoop sampling (similar to shovel sampling (Hakala 2000)) from Mullenax Run in May 1999. Sediment used in the trays was collected in Mullenax Run and nearby streams (Abe's Run, Elleber Run, Like Run, Little Low Place, Long Run, and Poca Run). The amount of each sediment size used in the treatments was based on percentages of a $2.91 \mathrm{~kg}$ mixture (the amount that would completely fill the trays). The sum of the weights of the size classes less than $2 \mathrm{~mm}$ was set as a proportion of $2.91 \mathrm{~kg}$ equal to the treatment class $(0-40 \%)$. Sediment mixtures were prepared in the lab by drying sediment collected in the streams at $100^{\circ} \mathrm{C}$ and sorting with the Wentworth sieve series (32 mm, $16 \mathrm{~mm}, 8 \mathrm{~mm}, 4 \mathrm{~mm}, 2 \mathrm{~mm}, 1 \mathrm{~mm}, 0.5 \mathrm{~mm}, 0.25 \mathrm{~mm}, 0.125 \mathrm{~mm}$, and $0.063 \mathrm{~mm}$ ). Mixtures were transported to the stream in individual plastic bags to be placed in circular trays $\left(0.3 \mathrm{~m}^{2}\right)$ within the stream. A description of the trays and their construction can be found in Angradi (1999).

Field experimentation began in the first week of June 1999 to take advantage of historically stable flows and weather patterns (Angradi 1999). The 1999 field experiment consisted of ten stations equally distributed in riffles through two sections of the stream. Each station received eight trays yielding a total of 80 sediment trays (Figure 2). The 
stream bottom within each riffle was excavated sufficiently deep for trays to be placed with their tops equal to the surrounding stream bottom. Five trays randomly received previously bagged substrate with one of the five manipulated mixtures. The other three trays received ambient sediment collected at the site. Fine $(<0.063 \mathrm{~mm})$ muslin was used to cover trays to prevent sediment loss during tray placement. Once in place in the stream, the muslin was removed from the trays.

The trays were left in place for five weeks to allow for colonization and stabilization of the macroinvertebrate populations as demonstrated by Shaw and Minshall (1980) and Angradi (1999). When the trays were removed, fine muslin was used to prevent sediment and macroinvertebrate loss when excess water was poured from the trays. Three Surber samples were taken at each station to detect any sampling artifacts caused by the trays themselves. Samples were placed into plastic containers and preserved in approximately $70 \%$ ethanol.

Field experimentation in the summer of 2000 began in the second week of June. Twelve stations were distributed equally in the two sections used in the summer 1999 experiment. Placement procedure followed the methodology of the previous summer with the exception of ambient sediment samples. Sediment for the ambient trays was collected previously, dried, and handled similarly to treatment mixtures to prevent "seeding" of trays with macroinvertebrates and periphyton collected on site as may have occurred in 1999. The experimental sites were visited once a week to monitor any loss of trays. After five weeks, all trays were removed, placed in plastic bags, and preserved with approximately $70 \%$ ethanol. Three Surber samples were taken at each station as was done in the previous experiment. Additionally, three flow measurements were 
taken by a Flowmate flow meter (nearest $0.1 \mathrm{~m} / \mathrm{s}$ ) above each tray from left to right perpendicular to stream flow.

\section{Laboratory methods}

In the lab, samples were dyed with Rose Bengal before sorting. Samples are washed through two sieves of $1 \mathrm{~mm}$ and $0.25 \mathrm{~mm}$. Macroinvertebrates collected on the $1 \mathrm{~mm}$ sieve were completely picked, enumerated, weighed and identified to lowest practical taxa, usually genus. Macroinvertebrates collected on the $0.25 \mathrm{~mm}$ sieve were subsampled using a method similar to the one described by Feminella (1996) and Angradi (1999). In this method, sediment and macroinvertebrates were diluted to a known $500 \mathrm{ml}$ volume in a $1000 \mathrm{ml}$ beaker. The sediment, macroinvertebrates, and water were agitated with an air hose system from which ten $10 \mathrm{ml}$ aliquots were taken by Hensen-Stemple pipette from the $500 \mathrm{ml}$ volume. These ten $10 \mathrm{ml}$ subsamples were completely enumerated under the microscope with identifications taken to the lowest practical level, usually family or order. After primary identification and enumeration, a $10 \%$ subsample of macroinvertebrates greater than $1 \mathrm{~mm}$ was identified and enumerated a second time with a second identification key (either Stewart and Stark 1988; Peckarsky et al. 1990; Merritt and Cummins 1996; Wiggins 1998) for quality control.

Once identified and enumerated, all macroinvertebrates were dried at $60^{\circ} \mathrm{C}$ for $48 \mathrm{~h}$., then placed in a desiccator for $24 \mathrm{~h}$., before weighing to the nearest $0.0001 \mathrm{~g}$ using an electronic balance. Drying for $48 \mathrm{~h}$. was experimentally determined to yield an 
unchanging mass with increasing time period. Dry mass (DM) was converted to ash free dry mass (AFDM) using conversions reported in Benke et al. (1999).

A random selection of $10 \%$ of the trays (12 trays) was used to determine changes in sediment composition of the treatments over the 5 week period in 2000. Samples were sorted using the same method as other trays except water used to wash the sample was collected in the original plastic bag. After macroinvertebrate removal, all sediment was dried at $100^{\circ} \mathrm{C}$, shaken in a Wentworth series of sieves, and weighed. The composition after the experiment was compared to the original sediment proportions to examine potential changes in sediment composition during the experiment.

Metrics

Metrics were selected primarily from those used to generate the Index of Biotic Integrity for western Maryland streams (Stribling et al. 1998). We assumed eastern West Virginia streams were similar to western Maryland streams. Additional metrics were added based upon previous studies in the region (Angradi 1999).

Macroinvertebrate density, biomass, diversity, and compositional metrics were calculated for each tray. Diversity metrics included number of families, EPT (Ephemeroptera, Plecoptera, and Trichoptera) taxa richness, Ephemeroptera taxa richness, Plecoptera taxa richness, Trichoptera taxa richness, Diptera taxa richness, Odonata taxa richness, and Coleoptera taxa richness (Stribling et al. 1998). Compositional metrics include \% EPT, \% Baetidae of Ephemeroptera, \% Chironomidae of Diptera, overall \% Chironomidae, \% Ephemeroptera, \% Trichoptera, \% Plecoptera, \% 
Odonata, \% Coleoptera, \% Diptera, \% Oligochaeta, \% non-insect, \% Amphipoda, \% Hydropsychidae of Trichoptera, \% swimmer, \% clinger, \% burrower, \% sprawler, \% collector, \% predator, \% shredder, and \% scraper (Stribling et al. 1998). Compositional metrics not advocated by Stribling et al. (1998), but used in this study based upon previous studies were non-insect richness, \% Heptageniidae, \% Baetidae, \% Cheumatopsyche, \% climber, \% Corydalidae, \% Decapoda, \% Epeorus spp., \% Ephemeridae, \% Ephemerellidae, \% Glossosomatidae, \% Hydropsychidae, \% Leptophlebiidae, \% Leucritidae, \% Leucrocuta spp., \% Limnephilidae, \% Megaloptera, \% Peltoperlidae, \% Perlidae, \% Perlodidae, \% Philopotamidae, \% Rhyacophilidae, \% Sialidae, \% Stenacron spp., and \% Stenonema spp. (Angradi 1999).

\section{Statistical analyses}

Statistical analyses performed on the data differed for each year due to concerns arising out of differing flow patterns at various sample sites observed in 1999. In each year, arcsine transformations were used on percentage metrics and any non-normal data (Krebs 1999). Linear regression was used in each year to test metric sensitivity to increasing amounts of fine sediment across the treatments. For ease in assessing any sampling artifacts caused by the trays, metrics were converted to unit area for both Surber and trays for the detection of sampling artifacts. Detection of sampling artifacts from the trays was conducted by using a t-test to compare Surber samples to ambient treatment trays. In 2000, due to concerns over differences in current velocities between trays possibly influencing macroinvertebrate distributions in the trays, multiple linear regression was used to examine the sensitivity of macroinvertebrate metrics to 
sediment in the context of varying current velocities (Fox 1984; Dowdy and Wearden 1991). In each year, the Dunn-Sidak method was used to adjust the $\alpha$-level to 0.01 to reduce experiment wise error rate from performing multiple statistical analyses on the same data set during tests of metric sensitivity (Sokal and Rohlf 1995).

\section{Results}

\section{Sampling artifacts}

In 1999, several metrics demonstrated an influence from the sampling method. The metrics Trichoptera, and Coleoptera taxa richness showed a difference between Surber samples and trays (Table 2). Tray composition had lower \% Trichoptera and Coleoptera taxa richness than Surber samples with comparable fine sediment composition.

In 2000, several more metrics indicated a possible tray sampling artifact. The metrics: overall macroinvertebrate density; EPT taxa richness; Ephemeroptera taxa richness; Diptera taxa richness; Plecoptera richness; Trichoptera taxa richness; \% Baetidae; and \% swimmer were all lower in ambient treatment trays than in Surber samples (Table 2).

Changes in substrate composition

Due to stable flows during the experimental period in 1999, tray composition was assumed to not have changed in the 1999 field experiment (NOAA/NCDC 1999, 2000; Ward et al. 2000). No trays were observed to have a complete sediment loss in 1999. 
Statistical analysis failed to find any significant differences in the sediment composition of the subsample of trays examined for changes in composition before and after the experiment in 2000 . Twelve other trays experienced a partial or complete sediment loss in 2000 during the field experiment and were excluded from the analyses.

\section{Macroinvertebrate response between ambient and treatment trays}

Analysis of the 1999 field experiment revealed numerous metrics differing between ambient sediment trays and treatment trays with a similar proportion of fine sediment (Table 3). Most metrics were lower in treatment trays than in similar ambient trays. In 2000, only one metric, EPT taxa richness, differed between ambient trays and treatment mixtures $(p<0.0001)$. EPT taxa richness was lower in the treatment trays than the ambient trays.

Metric response to fine sediment

In 1999, linear regression comparing metrics against fine sediment level in treatments revealed several metrics demonstrating a response to increasing fine sediment. The metric EPT taxa richness declined while \% climber increased in response to fine sediment $(<2 \mathrm{~mm})$ (Table 4, Figure 3). Metric response to fine sediment was not evident in statistical analyses in 2000.

\section{Discussion}

The 1999 field experiment 
Benthic macroinvertebrate metrics were tested across the range of sediment treatments to assess sensitivity to fine sediment to develop a set of metrics for sediment assessment. The range of sediment treatments in the experiment encompassed four levels observed in Monongahela National Forest streams (0\%, 10\%, 20\%, 30\%) and one level above observed amounts (40\%) (Angradi and Vinson 1996). The intention was to provide a wide level of treatments that might influence even taxa tolerant of fine sediment. In 1999, stream flows demonstrated remarkable stability during the experimental period, water chemistry was nearly identical between sample sites, temperature was nearly constant along the stream gradient used in sampling, trays were inundated throughout the course of the experiment, and all trays were recovered with their sediment mixtures intact. With such stability and consistency in experimental conditions, the 1999 experiment should have been able to validate or refute metrics found to be sensitive in previous research and concurrent stream surveys (Table 6).

However, only four metrics responded to increasing fine sediment in the 1999 experiment. The metrics EPT taxa richness was negatively related to fine $(<2 \mathrm{~mm})$ sediment while \% climber was positively related to fine $(<2 \mathrm{~mm})$ sediment in 1999 . In streams in the nearby Fernow experimental forest, Angradi (1999) found macroinvertebrate density, biomass, EPT richness, and \% Chironominae of Chironomidae declined with increasing fine $(<2 \mathrm{~mm})$ sediment while \% Orthocladiinae of Chironomidae and \% Baetidae of Ephemeroptera increased with increasing fine sediment. In Mullenax Run and six other nearby streams, benthic macroinvertebrate metrics assessed against $2 \mathrm{~mm}$ and smaller sediment size classes found EPT taxa richness to be negatively related to size classes smaller than $2 \mathrm{~mm}$ (specifically $<0.25$ 
$\mathrm{mm}$ and $<0.125 \mathrm{~mm}$ ) (Chapter 3). However, the 1999 experiment only corroborated an affect of fine sediment on EPT taxa richness.

A significant difference was noted in many metrics between trays with ambient sediment from Mullenax Run and trays with an introduced mixture with a similar sediment composition (Table 3). This sampling artifact probably arose from "seeding" the ambient trays with sediment collected directly from Mullenax Run. The ambient sediment contained organic matter, periphyton, and pre-existing populations of benthic macroinvertebrates that imparted an advantage in numbers and may also have attracted other macroinvertebrates into the ambient trays rather than trays with treatment mixtures. The evidence that "seeding" occurred in 1999 was best demonstrated by the absence of obvious "seeding" in 2000. In 2000, when ambient tray mixtures were handled in the same manner as the treatment mixtures, including sterilization in an oven during sample drying, differences in metrics between ambient mixtures and treatment mixtures were not as apparent. Therefore, in 1999, when "seeding" created stark differences between ambient and introduced sediment in the trays, macroinvertebrate distributions in sampling stations may have been influenced by optimal conditions (e.g. pre-existing organic matter, periphyton, and prey fauna) in ambient trays rather than sediment treatments.

It is important to note that despite the influences of declining flows and "seeding," EPT taxa richness and \% climber did respond to increasing fine sediment treatments in 1999. These are two metrics representative of taxonomic groups with known relationships to fine sediment within streams (Sandine 1974; Waters 1995; Angradi 1999). The 1999 experiment suggests these two metrics may have been sufficiently 
related to fine sediment to overcome experimental artifacts such as "seeding" of the trays

The 2000 field experiment

The 2000 experiment addressed some of the concerns arising from the 1999 experiment; yet, these measures were overshadowed by other factors. In 1999, sediment used in the experiment was a conglomerate arising from Mullenax Run and nearby streams (Elleber Run, Lick Run, Little Low Place, Long Run, and Poca Run). In 2000 , to reduce any effect of benthic macroinvertebrates avoiding unfamiliar substrate or other complications that may arise from introducing potentially geologically different sediment, all sediment used in the experiment was collected in Mullenax Run and Abe's Run both of which drain the same underlying geology. Sediment used in the 2000 experiment was handled in the same fashion whether it was used in a treatment or as an ambient mixture due to concerns over possible effects from "seeding" trays with preexisting benthic macroinvertebrate populations and organic matter. Flow measurements were taken at each tray to attempt to account for variations in flows between trays and sites that may have affected macroinvertebrate distribution. However, despite these additional precautions, neither multiple linear regression using fine sediment and flow in the model, principle component analysis (PCA), nor simple linear regression using only fine sediment uncovered any relationships between benthic macroinvertebrate metrics and increasing fine sediment treatments in 2000.

The inability to detect macroinvertebrate response to increasing fine sediment in 2000 may be reflective of other influences eliciting responses from the 
macroinvertebrates in the stream. Macroinvertebrates in intermittent streams can be influenced by the previous year's hydrology (Feminella 1996; Lake 2000). The same pattern of influence upon macroinvertebrates from the previous year's hydrology also may apply to perennial streams. Therefore, drought in 1999 may have influenced the macroinvertebrate populations in Mullenax Run during the 2000 experiment. In late summer 1999, drought conditions prevailed within Mullenax Run. Precipitation events were few and fairly light in 1999 compared to 2000 (NOAA/NCDC 1999, 2000) (Figure 4). Precipitation in the spring and early summer of 1999 was $1 / 3$ the amount over the same time period in 2000 , which was nearly identical to the 30 year average for the region (NOAA/NCDC 1999, 2000). When the previous winter's snowmelt no longer contributed to stream discharge, rainfall events in 1999 did not reach normal levels, and flows declined throughout the summer (Ward et al. 2000). The stream receded from the bank reducing wetted width and available habitat (Hakala 2000). In a drought, riffle habitat decreases at a faster rate than pool habitat (Hakala 2000). Indeed, area of available riffle habitat was significantly lower in 1999 than in the same time period in 2000 (Hakala 2000). Benthic macroinvertebrate communities in Mullenax Run were positively related to the area of available habitat in stream surveys (Chapter 3). Therefore, declines in the area of available riffle habitat in Mullenax Run could have caused a corresponding decline in benthic macroinvertebrates within the stream. Furthermore, since riffle area declined at a much greater rate than pool habitat, riffleassociated taxa, which is typically more abundant and diverse than pool taxa, would have declined at a faster rate than pool taxa resulting in a stream benthic macroinvertebrate community with an overall lower abundance and diversity. This 
phenomenon appeared to occur in Mullenax Run. In 1999, 143,671 individual macroinvertebrates were enumerated and identified in 80 trays and 30 Surber samples in the experiment ( $\mu=1250.4 \pm 1004.9$ SD). In 2000 , only 25,545 individual macroinvertebrates from 84 trays and 36 Surber samples participated in the study $(\mu=$ $270.56 \pm 530.52 \mathrm{SD}$ ). The mean number of macroinvertebrates in the trays was significantly lower in 2000 than in $1999(p<0.0001)$. Macroinvertebrates captured in the 2000 experiment declined despite an increase in sampling effort. Stream surveys conducted in Mullenax Run before and after the drought reflect declines in macroinvertebrate populations in the trays with declines in macroinvertebrate density in riffles (Chapter 3). Clearly, macroinvertebrate density declined in Mullenax Run between the 1999 experimental period and the 2000 experimental period due to the drought.

Additionally, taxonomic composition within the trays differed between years. A total of fifteen taxa were found in the 1999 experiment that were not present in 2000 (Table 5). In 2000, although overall diversity of taxa was less than in 1999 , four new taxa appeared in the experiment (Table 5). The taxa found in the trays, excluding ambient trays in 1999, was dependent on colonization from the stream. Presumably, if a taxonomic group was uncommon in the general stream macroinvertebrate community, it would have been unlikely that taxa would appear in the tray samples. Some of the differences in tray communities may be explained by the reduced probability of uncommon taxa colonizing the 2000 trays due to overall the lower macroinvertebrate population in Mullenax Run. Furthermore, the drought may have influenced taxonomic structure within the macroinvertebrate community by changing the availability of food 
sources. Lake (2000) reported droughts often reduce biomass and available resources within a stream channel. A reduction in leaf litter biomass available to macroinvertebrates appears to have occurred in Mullenax Run due to the drought. Leaf litter deposited in Mullenax Run may have fallen into dry areas normally part of the stream channel. In these areas, leaf litter may not have been sufficiently inundated reducing leaching time and microbial colonization (Murphy and Meehan 1991). Such leaf litter would be inadequately processed for many macroinvertebrates. This may have been responsible for some of the changes in taxonomic composition after the drought. The taxa missing in 2000 , but present in 1999, were associated with leaf litter (Lepidostomatidae (for cases), Nemouridae, Peltoperlidae, and Taeniopterygidae) and/or detritivory of plant material (Attenella spp., Dolichopodidae, Nemouridae, Peltoperlidae, Serratella spp., and Taeniopterygeridae) (Courtney et al. 1996; Edmunds and Waltz 1996; Wiggins 1996). These taxa were common in the 1999 experiment as well as in stream surveys of Mullenax Run prior to the drought, but were uncommon following the drought (Chapter 3). The absence of several taxonomic groups associated with a similar food source suggests the drought reduced the availability of this food source. Furthermore, the disappearance of Lepidostomatidae implies something other than desiccation of riffle habitat. Del Rosario and Resh (2000) reported Lepidostoma to be tolerant of desiccation in their study streams. Lepidostoma was a major component of the family Lepidostomatidae in Mullenax Run. If a taxonomic group known to be resilient in drought conditions disappears, it does suggest some other causative agent, perhaps a change in food sources. 
Another possibility known to influence taxonomic composition was the numerous spring spates in 2000 (Figure 4). Holomuzki and Biggs (2000) reported dislodgement rates increased for ephemeropterans and trichopterans as substrate instability increased in simulated spate events. Taxonomic composition in the trays with higher proportions of fine sediment may have lost taxa in a similar fashion due to inherent instability of high proportions of fine sediment. Regardless of cause, the trays exhibited a less diverse community in 2000 than in 1999.

In lotic systems, including streams in West Virginia, the hyporheos has been hypothesized as a refuge for benthic macroinvertebrates during dry periods (Williams and Hynes 1974; Griffith and Perry 1993). Yet, in other systems, the hyporheos does not serve as a refuge for benthic macroinvertebrates during dry periods (Boulton et al. 1992; Del Rosario and Resh 2000). In a nearby stream in the Fernow experimental forest, Angradi et al. (in press) found the hyporheos to harbor a great abundance and diversity of benthic macroinvertebrates. Therefore, since investigation of the hyporheos was beyond the scope of this project, the hyporheos may or may not have acted as a refuge in Mullenax Run.

The difficulties in detecting the influence of fine sediment in the 2000 sediment tray experiment suggests the relics of the drought in late summer 1999 may have overwhelmed the effects of fine sediment. The 2000 experiment suggests that experimental detection of an environmental disturbance, such as sediment, may not be feasible following another environmental disturbance within a system. Lake (2000) described how different types of disturbances occur within streams with different effects on the biota and different recovery periods. Sedimentation is described as a press 
disturbance with an initial increasing input (e.g. road construction) and long-term stable inputs (e.g. road runoff) while a drought is considered to be a ramp disturbance with one gradually worsening perturbation upon a stream with a long recovery period (Lake 2000). In Appalachian headwater streams, ramp disturbances, such as drought may overshadow the lesser, albeit persistent, effects of a press disturbance like fine sediment. This may be the case with the 2000 experiment where the stream may have been too early in recovery from drought to evaluate the more subtle effects of fine sediment. Future experimentation in headwater streams should consider the nature of the disturbance in question with regard to natural phenomenon at work within the stream. Some natural environmental disturbances may preclude investigation of lesser perturbations yielding inconclusive results when the same investigation performed without the influence of a potent environmental disturbance would yield a clearer picture of perturbation and response.

\section{Implications to monitoring forested Appalachian streams}

The evaluation of metrics in this experiment tested a wide range of sedimentation levels to examine the response of benthic macroinvertebrate metrics to fine sediment in a single stream experiment. The experimental treatments encompassed three levels found in streams sampled with similar equipment within the national forest $(0 \%, 10 \%$, $20 \%$, and $30 \%$ ) and one level exceeding amounts measured in streams (40\%) (Angradi and Vinson 1996; Chapter 3). In a 1995 survey of streams on the Monongahela National Forest, only one of 69 reaches on 42 streams exceeded $30 \%$ fine sediment (Angradi and Vinson 1996). Yet, macroinvertebrate communities have been 
compromised in forested Appalachian streams (Angradi and Vinson 1996; Angradi 1999; Chapter 3). Therefore, macroinvertebrate communities within these streams must be responding to the increasing gradient of fine sediment within streams with incremental changes in community composition. Waters (1995) describes several studies, including Appalachian research by D. R. Lenat and collaborators in North Carolina, that link increasing proportions of fine sediment in streams to a reduction in the amount of EPT taxa in a stream in favor of other taxonomic groups. A similar pattern of EPT taxa reduction occurred in Mullenax Run in 1999 experiments. Furthermore, this relationship between declining EPT taxa richness and increasing fine sediment demonstrated resilience against "seeding" of the trays.

Biomonitoring based on empirically and experimentally demonstrated relationships can yield efficient and timely tools for stream assessment (Karr and Chu 1999). This experiment further corroborates previous experiments and surveys of West Virginia streams emphasizing decreasing EPT taxa richness as an indicator of increasing fine sediment (Angradi 1999; Chapter 3) (Table 6). EPT taxa also are known to be sensitive to other environmental factors (e.g. temperature and acidity) in West Virginia streams (Clayton and Menendez 1996). Therefore, some caution must be used in interpreting declines in EPT taxa richness in streams before attributing the declines solely to fine sediment. Furthermore, the 2000 experiment suggests drought was a more powerful disturbance upon benthic macroinvertebrates than fine sediment. In the recovery period of a drought, EPT taxa richness does not appear to be a reliable metric in the detection of excess fine sediment. Further experimentation in several streams with a range of temperatures and $\mathrm{pH}$ levels may be able to differentiate between the 
various effects of fine sediment, temperature, and $\mathrm{pH}$ by identifying taxonomic assemblages within EPT sensitive to each type of perturbation. Additional experiments of this type may reveal situations where EPT taxa richness more or less reliable than other metrics. Under typical environmental conditions, EPT taxa richness appears to be the most reliable metric in the assessment of potentially deleterious fine sedimentation in forested northern Appalachian streams.

\section{Acknowledgements}

The authors thank the West Virginia University, the United States Forest Service (USFS), the MacIntyre-Stennis program, and Westvaco Corporation for funding this project. Karen Stevens and Donald Bolden of the USFS deserve particular thanks for their assistance in field collection and access. John Sweka and William Thayne provided statistical assistance. Matt Evix and Randy Cook assisted in the lab. Steven Harris of Clarion University and Janet Clayton of the West Virginia Department of Natural Resources assisted with taxonomic verification. Outstanding contributions to this project were made in the lab and field by Charles Sizemore, John W. Howell, Amy Patsos, and, especially, James Hakala.

\section{Literature Cited}

Angradi, T. R., Hood, R., and D. Tarter. Accepted. Vertical, longitudinal, and temporal variation in the macrobenthos of an Appalachian headwater stream system. American Midland Naturalist. In press. 
Angradi, T. R. 1999. Fine sediment and macroinvertebrate assemblages in Appalachain streams: a field experiment with biomonitoring applications. J. N. Am. Benthol. Soc. 18:43-65.

Angradi, T. R. and M. R. Vinson. 1996. Fine sediment - Aquatic macroinvertebrate relationships in headwater streams of the Monongahela National Forest: a Report to the Forest Supervisor. United States Department of Agriculture, Forest Service, Northeastern Forest Experiment Station NE-4301.

Benke, A. C., Huryn, A. D., Smock, L. A., and J. B. Wallace. 1999. Length-mass relationships for freshwater macroinvertebrates in North America with particular reference to the southeastern United States. J. N. Am. Benthol. Soc. 18:308-343.

Boulton, A. J., Peterson, C. G., Grimm, N. B., and S. G. Fisher. 1992. Stability of an aquatic macroinvertebrate community in a multiyear hydrologic disturbance regime. Ecology 73:2192-2207.

Clark, R. N. and D. R. Gibbons. 1991. Recreation. American Fisheries Society Special Publication 19: 459-479.

Clayton, J. L. and R. Menendez. 1996. Macroinvertebrate response to mitigative liming of Dogway Fork, West Virginia. Restoration Ecology 4:234-246.

Courtney, G. W., Teskey, H. J., Merritt, R. W., and B. A. Foote. 1996. Aquatic Diptera: Part One. Larvae of Aquatic Diptera. In An Introduction to the Aquatic Insects of North America ( $3^{\text {rd }}$ ed). Merritt, R. W. and K. W. Cummins, Eds. Kendall/Hunt Publishing Company. Dubuque, lowa.

Del Rosario, R. B. and V. H. Resh. 2000. Invertebrates in intermittent and perennial streams: is the hyporheic zone a refuge from drying? J. N. Am. Benthol. Soc. 19:680696.

Dowdy, S. and S. Wearden. 1991. Statistics for research, $2^{\text {nd }}$ ed. John Wiley \& Sons, Inc., New York, New York.

Edmunds, G. F., Jr. and R. D. Waltz. 1996. Ephemeroptera. In An Introduction to the Aquatic Insects of North America ( $3^{\text {rd }}$ ed). Merritt, R. W. and K. W. Cummins, Eds. Kendall/Hunt Publishing Company. Dubuque, lowa.

Feminella, J. W. 1996. Comparison of benthic macroinvertebrate assemblages in small streams along a gradient of flow permanence. J. N. Am. Benthol. Soc. 15:651-669.

Fox, J. 1984. Linear statistical models and related methods: With applications to social research. John Wiley and Sons. New York, New York. 
Furniss, M. J., Roelofs, T. D., and C. S. Yee. 1991. Road construction and maintenance. In Influences of forest and rangeland management on salmonids and their habitats. Meehan, W. R., ed. Special Publication 19, American Fisheries Society. Bethseda, Maryland.

Gardner, R. B. 1979. Some environmental and economic effects of alternative forest road designs. Transactions of the ASAE 22:63-68.

Griffith, M. B. and S. A. Perry. 1993. The distribution of macroinvertebrates in the hyporheic zone of two small Appalachian headwater streams. Archiv fur Hydrobiologia 126:373-384.

Grost, R.T., Hubert, W.A., and T.A. Wesche. 1991. Field comparison of three devices used to sample substrate in small streams. North American Journal of Fisheries Management 11:347-351.

Grubaugh, J. W., Wallace, J. B., and E. S. Houston. 1996. Longitudinal changes of macroinvertebrate communities along an Appalachian stream continuum. Can. J. Fish. Aquat. Sci. 53:896-909.

Harding, J. S., Benfield, E. F., Bolstad, P. V., Helfman, G. S., and E. B. D. Jones III. 1998. Stream biodiversity: The ghost of land use past. Proc. Nat. Acad. Sci. USA 95:14843-14847.

Hakala, J. P. 2000. Factors influencing brook trout (Salvelinus fontinalis) abundance in forested headwater Appalachian streams with emphasis on fine sediment. West Virginia University. M.S. Thesis.

Holomuzki, J. R. and B. J. F. Biggs. 2000. Taxon-specific responses to high-flow disturbance in streams: implications for population persistence. J. N. Am. Benthol. Soc. 19:670-679.

Karr, J. R. and E. W. Chu. 1999. Restoring life in running waters: Better biological monitoring. Island Press. Washington, D. C.

Kochenderfer, J. N., Edwards, P. J., and F. Wood. 1997. Hydrologic impacts of logging an Appalachian watershed using West Virginia's Best Management Practices. Northern Journal of Applied Forestry 14:207-218.

Krebs, C. J. 1999. Ecological Methodology. Benjamin/Cummings. Menlo Park, California.

Lake, P. S. 2000. Disturbance, patchiness, and diversity in streams. J. N. Am. Benthol. Soc. 19:573-592. 
Mason, J. C. 1976. Evaluating a substrate tray for sampling the invertebrate fauna of small streams, with comment on general sampling problems. Arch. Hydrobiologica 78:51-70.

McMahon, T. E., Zale, A. V., and D. J. Orth. 1996. Aquatic habitat measurements. Pages 83-115. In Fisheries Techniques, $2^{\text {nd }}$ edition. Murphy, B. R., and D. W. Willis, Eds. American Fisheries Society, Bethseda, MD.

Meehan, W.R. 1991. Introduction and overview. In Influences of forest and rangeland management on salmonids and their habitats. Meehan, W. R., ed. Special Publication 19, American Fisheries Society. Bethseda, Maryland.

Merritt, R. W. and K.W. Cummins. 1996. An introduction to the aquatic insects of North America $3^{\text {rd }}$ ed. Kendall Hunt Publishing Company. Dubuque, lowa.

Murphy, M. L. and W. R. Meehan. 1991. Stream ecosystems. In Influences of forest and rangeland management on salmonids and their habitats. Meehan, W. R., ed. Special Publication 19, American Fisheries Society. Bethseda, Maryland.

NOAA/NCDC 1999, 2000. Data provided by the National Oceanic and Atmospheric Administration's National Climate Data Center.

Peckarsky, B. L., Fraissinet, P. R., Penton, M. A., and D. J. Conklin, Jr. 1990. Freshwater macroinvertebrates of northeastern North America. Comstock Publishing Associates. Ithaca, New York.

Quinn, J. M. and C. W. Hickey. 1990. Magnitude of effects of substrate particle size, recent flooding, and catchment development on benthic invertebrates in $88 \mathrm{New}$ Zealand rivers. New Zealand Journal of Marine and Freshwater Research 24:411-427.

Resh, V. H., Norris, R. H., and M. T. Barbour. 1995. Design and implementation of rapid assessment approaches for water resource monitoring using benthic macroinvertebrates. Australian Journal of Ecology 20:108-121.

Richards, C. and K. L. Bacon. 1994. Influence of fine sediment on macroinvertebrate colonization of surface and hyporheic stream substrates. Great Basin Naturalist 54:106113.

Rosemond, A. D., Reice, S. R., Elwood, J. W., and P. J. Mulholland. 1992. The effects of stream acidity on benthic invertebrate communities in southeastern United States. Freshwater Biology 27:193-209.

Rosenberg, D. M. and V.H. Resh. 1996. Use of aquatic insects in biomonitoring. Pages 87-97. In An Introduction to the Aquatic Insects of North America ( $3^{\text {rd }}$ ed.) Merritt, R. W. and K. W. Cummins, Eds. Kendall/Hunt Publishing Company. Dubuque, lowa. 
Sandine, M. E. 1974. Natural and simulated insect-substrate relationships in Idaho Batholith streams. University of Idaho. M.S. thesis.

Shaw, D. G. and G. W. Minshall. 1980. Colonization of an introduced substrate by stream macroinvertebrates. Oikos 34:259-271.

Stewart, R. 1999. Concerning the Forest Service revised road policy. Statement of Ron Stewart, Deputy Chief, Forest Service, United States Department of Agriculture, before the Subcommittee on Forests and Forest Health, Committee on Resources, United States House of Representatives, March 4, 1999.

Stribling, J. B., Jessup, B. K., and J. S. White. 1998. Development of a Benthic Index of Biotic Integrity for Maryland Streams. Chesapeake Bay and Watershed Programs Monitoring and Non-tidal Assessment. CBWP-MANTA-EA-98-3.

Stewart, K. W. and B. P. Stark. 1988. Nymphs of the North American stonefly genera (Plecoptera). Entomological Society of America. College Park, Maryland.

Surber, E. W. 1953. Biological effects of pollution in Michigan waters. Sewage and Industrial Wastes 25:79-86.

Swift, L. W., Jr. 1988. Forest access roads: design, maintenance, and soil loss. Pages 313-324. In Forest Ecology and Hydrology at Coweeta. Swank, W.T., and D. A. Crossley, Jr., Eds. Ecological Studies 66.

Tebo, L. B. 1955. Effect of siltation, resulting from improper logging, on bottom fauna of a small trout stream in the Appalachains. Progressive Fish-Culturist 17:64-70.

Vouri, K. and I. Joensuu. 1996. Impact of forest drainage on the macroinvertebrates of a small boreal headwater stream: Do buffer zones protect lotic biodiversity? Biological Conservation 77:87-95.

Ward, S. M., Taylor, B. C., and G. R. Crosby. 2000. Water resources data, West Virginia, water year 1999: United States Geological Survey Water-Data Report WV_99_1.

Waters, T. F. 1995. Sediment in streams: sources, biological effects, and control. American Fisheries Society Monograph 7. American Fisheries Society. Bethseda, Maryland.

Wiggins, G. B. 1998. Larvae of the North American caddisfly genera (Trichoptera), $2^{\text {nd }}$ ed. University of Toronto Press. Toronto, Ontario, Canada.

Wiggins, G. B. 1996. Trichoptera families. In An Introduction to the Aquatic Insects of North America ( $3^{\text {rd }}$ ed). Merritt, R. W. and K. W. Cummins, Eds. Kendall/Hunt Publishing Company. Dubuque, lowa. 
Williams, D. B. and H. B. N. Hynes. 1974. The occurrence of benthos deep in the substratum of a stream. Freshwater Biology 4:233-256. 


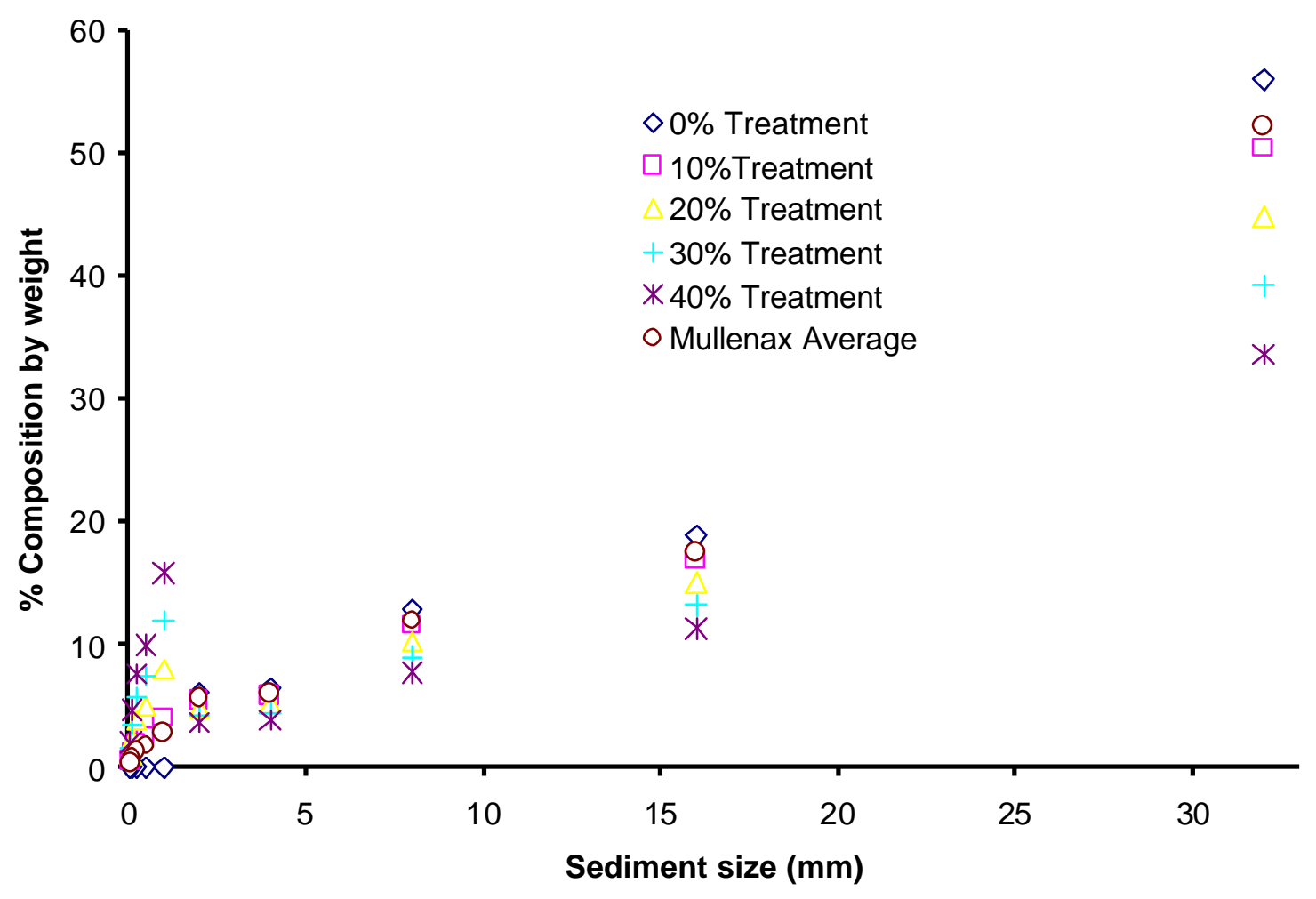

Figure 1. Fine sediment treatments and Mullenax average. 


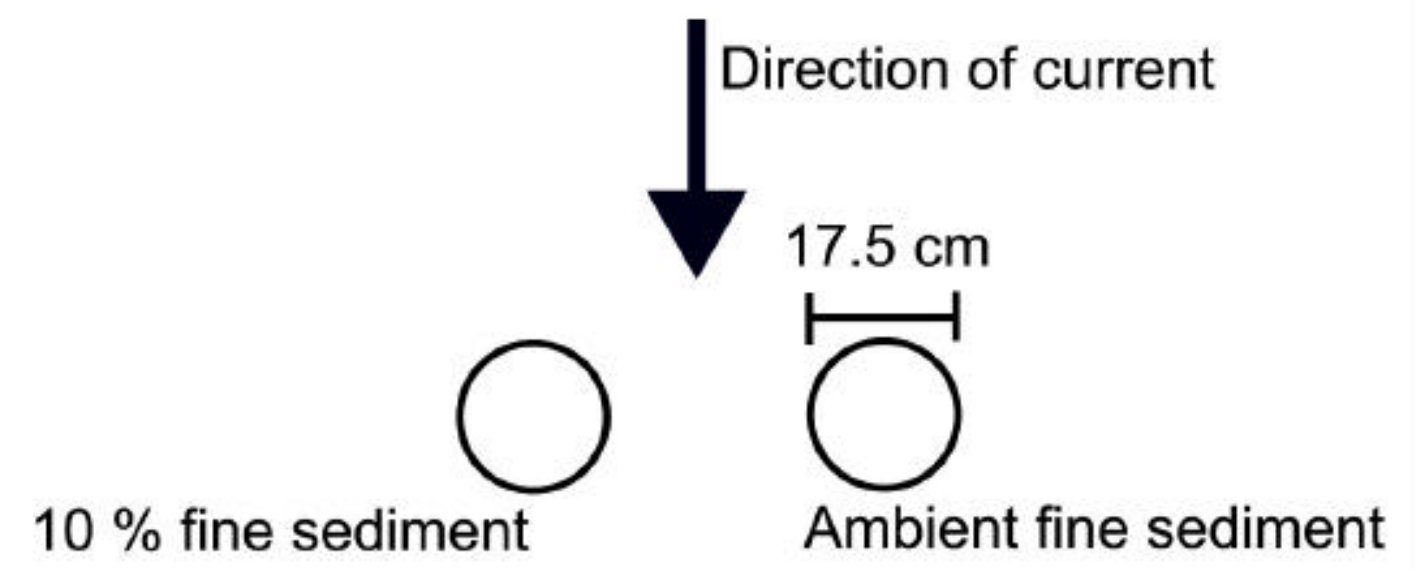

Ambient fine sediment

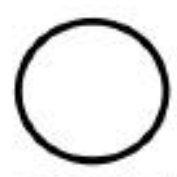

$30 \%$ fine sediment

$20 \%$ fine sediment

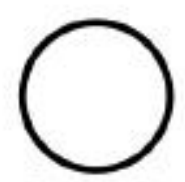

$0 \%$ fine sediment

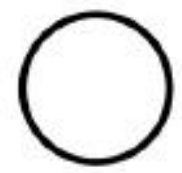

Ambient fine sediment

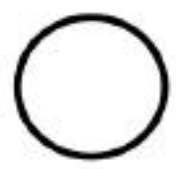

$40 \%$ fine sediment

Figure 2. One of the randomizations of manipulated and ambient treatments used in the summers of 1999 and 2000. Each of the 10 stations received a different randomization of trays. 

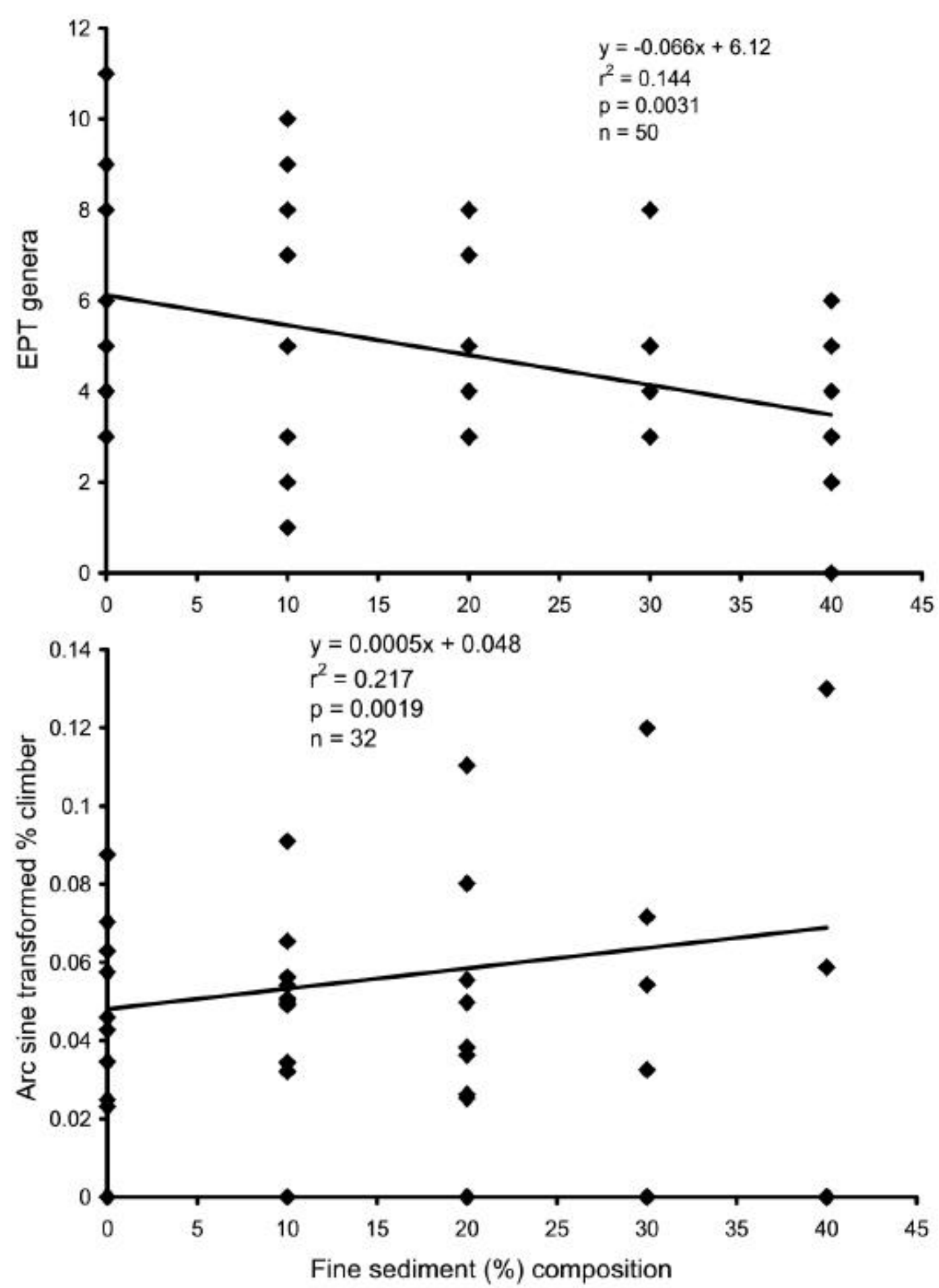

Figure 3. Metric responses to increasing fine sediment treatments in 1999. Individual trays at each treatment level are shown. 

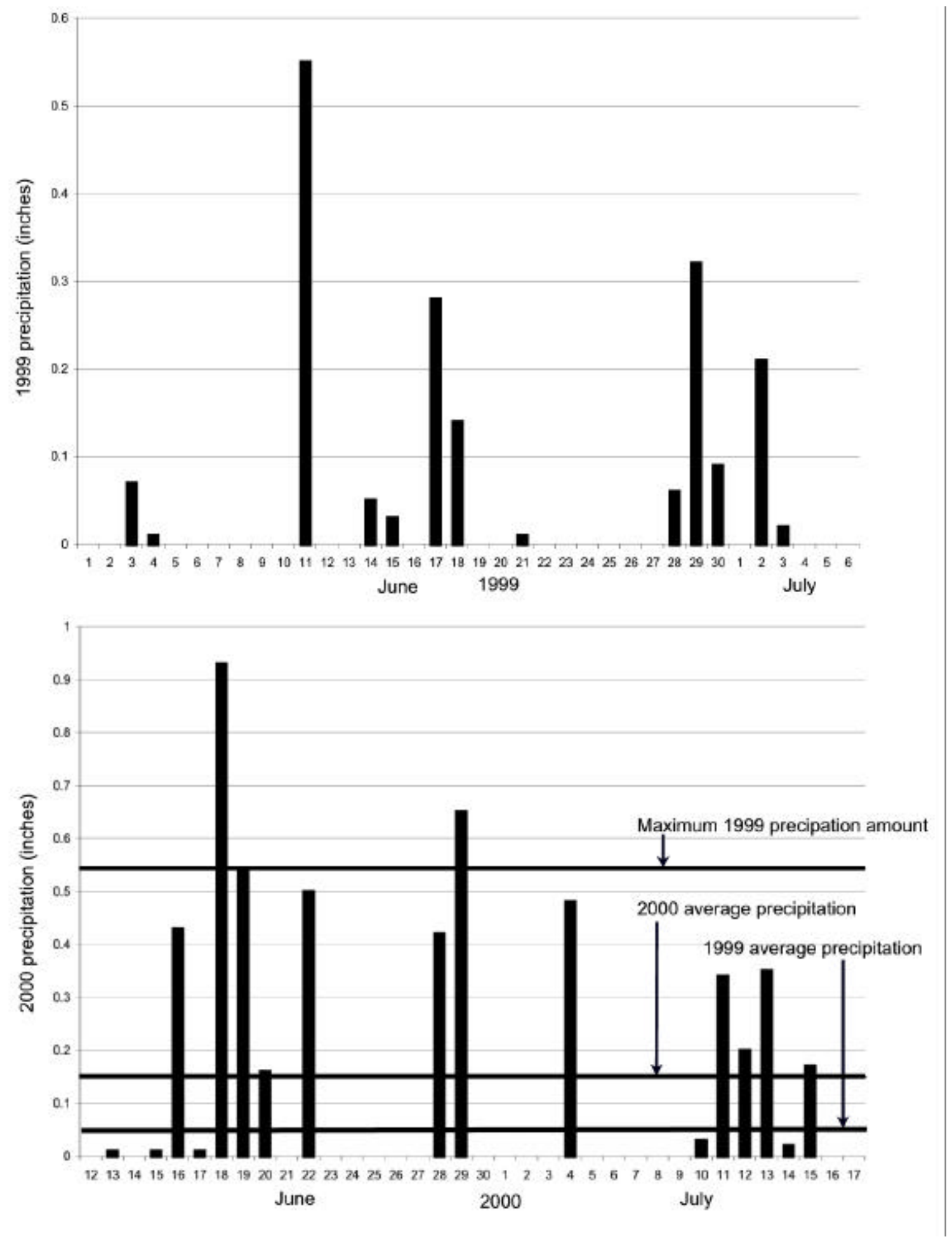

Figure 4. Precipitation amounts for experimental periods in 1999 and 2000. Trays were placed on the first date in each graph and removed on the last date. Rainfall was recorded in Bartow, WV by NOAA/NCDC. 
Table 1. Physical and chemical characteristics of Mullenax Run.

\begin{tabular}{lrr}
\hline & 1999 & 2000 \\
& & \\
\hline Slope (\%) & 11.5 & 11.5 \\
Avg. pH & 7.3 & 6.9 \\
Avg. Summer Temp (Celsius) & 15.3 & 14.9 \\
High Yearly Temp (Celsius) & 22.9 & 21.2 \\
Low Yearly Temp (Celsius) & -0.1 & -0.2 \\
Fine sediment (\%<2mm) & 9.3 & 1.1 \\
Avg. Discharge (m/s) & 0.0 & 0.1 \\
DO (mg/L) & 7.1 & 9.1 \\
Specific Conductance & 42.8 & 17.3 \\
Dissolved Organic Carbon (mg/L) & $\mathrm{NA}$ & 2.5 \\
Alkalinity (mg/L) & $\mathrm{NA}$ & 4.9 \\
Calcium (mg/L) & $\mathrm{NA}$ & 2.5 \\
\hline & & \\
\hline
\end{tabular}


Table 2. Significant differences between Surber samples and ambient trays, (comparable fine sediment composition in each) indicating sampling artifact caused by the trays.

1999

\begin{tabular}{lrr} 
& p-value & Tray effect \\
\hline \% Elmidae & 0.02 & $(+)$ \\
Coleoptera taxa richness & 0.0007 & $(-)$ \\
& & 2000 \\
\hline Macroinvertebrate density & $<0.0001$ & $(-)$ \\
Ephemeroptera taxa richness & $<0.0001$ & $(-)$ \\
EPT richness & $<0.0001$ & $(-)$ \\
Diptera taxa richness & $<0.0001$ & $(-)$ \\
Plecoptera taxa richness & $<0.0001$ & $(-)$ \\
Trichoptera taxa richness & $<0.0001$ & $(-)$ \\
\% Baetidae & $<0.0001$ & $(-)$ \\
\% swimmer & $<0.0001$ & $(-)$ \\
\hline
\end{tabular}

$(+)$ or (-) indicates higher or lower values in the trays 
Table 3. Differences in metrics between ambient trays $(\%<2 \mathrm{~mm}=9.3)$ and 10\% treatment level in 1999.

Metric

p-value Treatment effect

\begin{tabular}{lll} 
Macroinvertebrate density & $<0.0001$ & $(-)$ \\
Macroinvertebrate biomass & $<0.0001$ & $(-)$ \\
Ephemeroptera taxa richness & $<0.0001$ & $(-)$ \\
EPT taxa richness & $<0.0001$ & $(-)$ \\
Plecoptera taxa richness & $<0.0001$ & $(-)$ \\
Trichoptera taxa richness & $<0.0001$ & $(-)$ \\
Diptera taxa richness & $<0.0001$ & $(+)$ \\
Odonata taxa richness & 0.0263 & $(+)$ \\
\% Chironomidae & $<0.0001$ & $(+)$ \\
\% Diptera & $<0.0001$ & $(+)$ \\
\% burrower & $<0.0001$ & $(+)$ \\
\% climber & $<0.0001$ & $(+)$ \\
\% collector & $<0.0001$ & $(+)$ \\
\hline
\end{tabular}

$(+)$ or (-) indicates higher or lower values in treament trays 
Table 4. Metric response to increasing fine sediment $(<2 \mathrm{~mm})$ tested by linear regression across treatment groups.

\begin{tabular}{lll}
\hline \multicolumn{1}{c}{ Metric } & $r^{2}$ & p-value \\
& & \\
\hline EPT richness & -0.144 & 0.0031 \\
$\%$ Climber & 0.217 & 0.0019 \\
\hline
\end{tabular}


Table 5. Different taxonomic groups present between 1999 and 2000 tray experiments.

1999

2000

Ameletus spp. (Ephemeroptera: Ephemerellidae)

Amphizoidae (Coleoptera)

Attenella spp. (Ephemeroptera: Ephemerellidae)

Dixidae (Diptera)

Dolichopodidae (Diptera)

Gammarus spp. (Amphipoda: Gammaridae)

Lepidostomatidae (Trichoptera)

Nemouridae (Plecoptera)

Nepticulidae (Lepidoptera)

Odontoceridae (Trichoptera)

Phyrageidae (Trichoptera)

Peltoperlidae (Plecoptera)

Pleidae (Hemiptera)

Saldidae (Hemiptera)

Serratella spp. (Ephemeroptera: Ephemerellidae)

Spaeromatidae (Isopoda)

Taeniopterygidae (Plecoptera)
Blephaceridae (Diptera)

Brachycentridae (Trichoptera)

Eurylophella spp. (Ephemeropter: Ephemerellidae)

Goeridae (Trichoptera) 
Table 7. Summary of metric responses to in recent Appalachian studies.

\begin{tabular}{|c|c|c|}
\hline Metric & Response & Source \\
\hline$\%$ Ameletidae & $(+)$ & Chapter 3 \\
\hline$\%$ Baetidae of Ephemeroptera & $(+)$ & Angradi 1999; Chapter 3 \\
\hline$\%$ Chironomidae of Chironomidae & $(-)$ & Angradi 1999 \\
\hline$\%$ Chironomidae of Diptera & $(-)$ & Chapter 3 \\
\hline$\%$ Chloroperlidae & $(-)$ & Chapter 3 \\
\hline$\%$ Climber & $(+)$ & Summer 1999 experiment \\
\hline$\%$ Clinger & $(-)$ & Chapter 3 \\
\hline$\%$ Ephemeridae & $(+)$ & Chapter 3 \\
\hline$\%$ Heptageniidae & $(-)$ & Chapter 3 \\
\hline$\%$ Hydropsychidae & $(+)$ & Chapter 3 \\
\hline$\%$ Hydropsychidae of Trichoptera & $(-)$ and $(+)$ & Chapter 3 \\
\hline$\%$ Leucrtidae & $(+)$ & Chapter 3 \\
\hline$\%$ Leucrocuta & $(-)$ & Chapter 3 \\
\hline \% Limnephilidae & $(+)$ & Chapter 3 \\
\hline$\%$ Non-insect & $(+)$ & Chapter 3 \\
\hline$\%$ Odonata & $(+)$ & Chapter 3 \\
\hline$\%$ Oligochaeta & $(+)$ & Chapter 3 \\
\hline$\%$ Orthocladiinae of Chironomidae & $(+)$ & Angradi 1999 \\
\hline \% Perlodidae & $(+)$ & Chapter 3 \\
\hline$\%$ Philopotamidae & $(+)$ & Chapter 3 \\
\hline$\%$ Polycentropodidae & $(+)$ & Chapter 3 \\
\hline$\%$ Scraper & $(-)$ & Chapter 3 \\
\hline$\%$ Swimmer & $(+)$ & Chapter 3 \\
\hline \% Tricoptera & $(+)$ & Chapter 3 \\
\hline EPT taxa richness & $(-)$ & Angradi 1999; Chapter 3; Summer 1999 experiment \\
\hline Ephemeroptera taxa richness & $(-)$ & Chapter 3 \\
\hline Odonata taxa richness & $(+)$ & Chapter 3 \\
\hline Plecoptera taxa richness & $(-)$ and $(+)$ & Chapter 3 \\
\hline Trichoptera taxa richness & $(-)$ and $(+)$ & Chapter 3 \\
\hline Macroinvertebrate biomass & $(-)$ & Angradi 1999 \\
\hline Macroinvertebrate density & $(-)$ & Angradi 1999; Chapter 3 \\
\hline Non-insect taxa richness & $(-)$ & Summer 1999 experiment \\
\hline
\end{tabular}

(+) or (-) indicates direction of response. 


\title{
Effects of substrate composition on benthic macroinvertebrate metrics in forested northern Appalachian streams
}

\author{
Michael D. Kaller and Kyle J. Hartman \\ Division of Forestry, West Virginia University, Box 6125, Morgantown, WV 26505
}

Abstract: Benthic macroinvertebrate density and community composition within streams fluctuates in response to environmental variables within the stream. When anthropogenic activities alter natural hydrologic and sediment delivery regimes, the affects usually are negative to macroinvertebrates. In the northern Appalachians, anthropogenic activities often elevate inputs of fine sediment into the stream. It is of interest to stream ecology to quantify the relationships between macroinvertebrate metrics and fine sediment accumulation in the substrate to determine the suitability of metrics for stream assessment. It also is of interest to examine these relationships in the context of other disturbances such as floods and droughts. We surveyed macroinvertebrate communities in seven Appalachian streams twice a year beginning in the fall of 1998 and continuing through the spring of 2000 . Three riffles and three pools (with two replicates each) were sampled via Surber sampler or excavated core sampler in each season in each stream. Simple linear regression was used to test relationships between substrate size classes and macroinvertebrate density and community in each season. Consistent negative relationships with the finest substrate particles $(<0.25 \mathrm{~mm})$ were observed with EPT (Ephemeroptera, Plecoptera, and Trichoptera) taxa richness and related indices within the macroinvertebrate community in both spring and fall over 
the course of the study. Fine substrate particles $(<0.25 \mathrm{~mm})$ were found to influence EPT taxa richness within the macroinvertebrate community when in excess of about $1 \%$ of the substrate composition in the study streams. However, in drought seasons, the influence of fine sediment was obscured.

Keywords: benthic macroinvertebrates, biomonitoring, drought, roads, sediment, substrate, threshold.

\section{Introduction}

Substrate particle size distribution influences benthic macroinvertebrate community composition in streams. Higher density and diversity in benthic macroinvertebrate community structure have been reported in cobble and pebble substrates while sand and silt-dominated substrates have lower densities and diversities (Tebo 1955; Sandine 1974; Waters 1995; Grubaugh et al. 1996; Quinn and Hickey 1996; Vuori and Joensuu 1996). The macroinvertebrate-substrate relationships described in these papers involved comparisons between macroinvertebrates and rather broad substrate categories outlined by Cummins (1962). These broad categories have been used to describe the deleterious effects of excessive amounts of fine particles in the substrate (Rosenberg and Wiens 1978; Brunke and Grosver 2000). Broad categories provide a quick and easy method for visual assessment of substrate composition (McMahon et al. 1996). However, broad categories do not allow for the identification of specific relationships between macroinvertebrates and particular sizes and amounts of fine sediment. 
Different anthropogenic activities subject streams to different amounts, sizes, and types of sedimentation. Silviculture can initially contribute larger particles due to hillslope destabilization with elevated inputs of smaller particles continuing until hillslope revegetation occurs(Leopold et al. 1964). Streamside agriculture may produce finer particles for a much longer duration (Lamberti and Berg 1995). Roads may initially input larger particles during construction but continue to deliver smaller particles during the lifespan of their operation (Gardner 1979; Bilby et al. 1989; Constantini et al. 1999). Addressing the impacts of differing sediment inputs from different sources requires an understanding of the effects of particular particle sizes and amounts upon benthic macroinvertebrates.

In the Appalachians, application of forestry Best Management Practices (BMPs) has reduced sediment input from silviculture operations (Kochenderfer et al. 1997). Anthropogenic perturbations continue, however, in the form of remnant mountain farming, strip and valley-fill mining, and an extant road network from past logging operations (Nelson et al. 1991; Furniss et al. 1991; Harding et al. 1998). Postconstruction road inputs of sediment tend to be of the finest particle sizes (Bilby et al. 1989; Constantini et al. 1999). Constantini et al. (1999) reported large volumes of sediment $<0.02 \mathrm{~mm}$ in road run-off while Bilby et al. (1989) reported the majority of sediment in road run-off to be $<0.004 \mathrm{~mm}$ in size. Since many past studies used broad categories to describe the substrate composition related to macroinvertebrates, it is difficult to predict the effects of very fine $(0.004-0.02 \mathrm{~mm})$ particles from road erosion upon macroinvertebrates using the relationships from previous studies. 
Therefore, it is of interest to examine the declines in macroinvertebrate community diversity reported in the sand and silt categories to attempt to identify the particular sizes and amounts culpable for macroinvertebrate responses. A combination of the understanding of the effects of particular amounts and sizes of fine sediment and the nature of sedimentation from various sources can be used to assist in decision making regarding remediation of past and present anthropogenic activities as well as predicting the effects of future disturbances.

Relationships developed between bioassessment metrics used to describe macroinvertebrate community structure and density and substrate size provide the necessary empirical evidence to utilize benthic metrics to identify present, and predict future effects from disturbance (Angradi 1999; Karr and Chu 1999). In a similar effort, Richards and Bacon (1994) investigated the influence of fine sediment particles and found $0.015 \mathrm{~mm}$ sized sediment to have significant effects on macroinvertebrate total numbers and diversity. However, the research focused on influences on colonization and did not investigate macroinvertebrate response to perturbation from sedimentation (Richards and Bacon 1994). The present study tests the effects of fine sediment sizes (grouped into classes of \% less than $\mathrm{x} \mathrm{mm}$ as described by Waters (1995)) on macroinvertebrate metrics (reflective of density and diversity) in order to provide evidence of relationships between substrate particle size and amounts and benthic macroinvertebrate metrics. Specifically, this study relates macroinvertebrate metrics to narrow size classes of sediment, including sizes and amounts of fine sediment within the range produced by road erosion, to provide a biological tool for assessment in streams within the northern Appalachians. Furthermore, the relationships between 
sediment and macroinvertebrates are tested for four seasons over two years to assess the impacts of seasonal and temporal variability. Such relationships may be used by land managers in decision making processes in future land use and BMPs.

\section{Study sites}

This study encompassed seven streams on the Monongahela National Forest in Pendleton and Pocohantas counties of east central West Virginia. Five of the streams were tributaries of the East Fork of the Greenbrier River (Elleber Run, Lick Run, Long Run, Mullenax Run, and Poca Run). Two streams were tributaries of the South Branch of the Potomac River (Little Low Place and Sawmill Run). All of these streams were first or second order. Upstream boundaries to sampling were beaver ponds on Lick Run and Long Run. Road crossings marked the upstream boundaries for sampling on Elleber Run and Sawmill Run. Confluences with tributaries substantial enough to change stream order formed the upstream boundaries on Little Low Place, Mullenax Run, and Poca Run. Only Long Run had a road crossing between sample reaches. Little Low Place had 19 fish habitat improvement structures (K-dams).

\section{Methods}

\section{Macroinvertebrate collection}

In the fall of 1998, sample reaches were selected in 6 of the 7 streams included in this study. Streams were chosen based upon existing United States Department of 
Agriculture Forest Service (USDA Forest Service) stream sedimentation data (Thomas Cain, USDA Forest Service, pers. comm.) in an effort to select streams reflective of a wide range of fine sediment levels. Three sample reaches were placed in each stream except for Sawmill Run. Sample reaches were chosen as representative of the majority of the habitat available in the streams. Within each sample reach, two Surber samples were taken in a representative riffle, and two excavated core samples were taken in a representative pool (Karr and Chu 1999). All samples were field preserved in $70 \%$ ethanol.

Macroinvertebrate collection was repeated three additional seasons, spring 1999, fall 1999, and spring 2000, with the addition of Sawmill Fork in spring 1999 and subsequent sample seasons. Sawmill Fork was added to increase the range of ambient fine sediment in the stream survey.

\section{Sediment collection}

Sediment samples were taken concurrently with the macroinvertebrate collections. Two sediment collections were made in each sample reach in the same riffle, if possible, as the Surber sample was taken. Sediment samples were taken in riffles because pools collect fine sediment even in unimpacted streams; however, riffles accumulate fine sediment when perturbations increase sedimentation regimes beyond a streams ability to cleanse itself (Luepold et al. 1964; Swanston 1991). Fine sediment levels in riffles were considered to be reflective of increasing fine sediment impacts upon the stream. Sediment samples were taken with a grain scoop in a method similar to the shovel method described by Grost et al. (1991). A concurrent study on the same 
streams did not find a difference between sediment collected with a shovel or grain scoop (Hakala 2000); therefore, a grain scoop was used for all sediment collections in this study. Sediment was returned to the lab, dried at $100^{\circ} \mathrm{C}$ for $24 \mathrm{~h}$., shaken through a Wentworth sieve series $(32 \mathrm{~mm}, 16 \mathrm{~mm}, 8 \mathrm{~mm}, 4 \mathrm{~mm}, 2 \mathrm{~mm}, 1 \mathrm{~mm}, 0.5 \mathrm{~mm}, 0.25 \mathrm{~mm}$, $0.125 \mathrm{~mm}$, and $0.63 \mathrm{~mm}$ ) and weighed to the nearest $0.1 \mathrm{~g}$.

Physical habitat assessment and water chemistry collection

Stream physical habitat was assessed in the summers of 1999 and 2000. Habitat within the streams was measured using the Basinwide Visual Estimation Technique (Hankin and Reeves 1988). All measurements were taken during base flow. (Ward et al. 2000). Temperature was measured and recorded in each stream using an Onset Hobotemp temperature logger.

Stream water chemistry was sampled during each macroinvertebrate collection for $\mathrm{pH}$ and additional measurements of specific conductance and dissolved oxygen were made during the habitat assessments. Storm samples were collected on 13 February 2000 on Lick Run, Long Run, Poca Run, and Sawmill Run and on all seven streams on 24 May 2000. Storm samples were analyzed for dissolved organic carbon (DOC), acid neutralizing capacity (ANC), alkalinity, magnesium, calcium, total aluminum, organic aluminum, and inorganic aluminum. Water chemistry samples were analyzed at the Appalachian Laboratory, Frostburg, MD, USA using United States Environmental Protection Agency standardized methods. 
In the lab, samples were dyed with rose bengal before sorting was begun. Samples were analyzed using a two-phase sorting method. Samples were washed through two sieves of $1 \mathrm{~mm}$ and $0.25 \mathrm{~mm}$ size. Macroinvertebrates collected on the $1 \mathrm{~mm}$ sieve were completely picked, enumerated, weighed and identified to lowest practical taxa, usually genus. Macroinvertebrates collected on the $0.25 \mathrm{~mm}$ sieve were subsampled using a method similar to the one described by Feminella (1996) and Angradi (1999). Sediment and macroinvertebrates collected on the $0.25 \mathrm{~mm}$ sieve were diluted to a volume of $500 \mathrm{ml}$ in a $1000 \mathrm{ml}$ beaker. The sediment, macroinvertebrates, and water were agitated with an air hose system. Ten $10 \mathrm{ml}$ aliquots were taken by Hensen-Stemple pipette from the $500 \mathrm{ml}$ volume. These ten 10 $\mathrm{ml}$ subsamples were completely enumerated under the microscope with identifications taken to the lowest practical level, usually family or order. For quality control, after primary identification and enumeration, a $10 \%$ subsample of macroinvertebrates was identified and enumerated a second time with a second identification key. If macroinvertebrate identity differed between keys, the macroinvertebrate was reexamined until both keys yielded the same identification.

All macroinvertebrates were dried at $60^{\circ} \mathrm{C}$ for $48 \mathrm{~h}$., placed in a dessicator for 24 h., and weighed using an electronic scale (Benke et al. 1999). Dry mass (DM) was converted to ash free dry mass (AFDM) using conversions reported in Benke et al. (1999).

\section{Metrics}


Metrics were selected primarily from those used to generate the Index of Biotic Integrity for western Maryland streams (Stribling et al. 1998). We assumed eastern West Virginia streams were similar to western Maryland streams. Additional metrics not included by Stribling et al. (1998) were added based upon previous studies in the region (Angradi 1999; Chapter 2). Macroinvertebrate density, biomass, diversity, and compositional metrics were calculated for each sample. Metrics were weighted by habitat by multiplying the metric by the proportion of its habitat type in the sample section. Diversity metrics included: number of families, EPT (Ephemeroptera, Plecoptera, and Trichoptera) taxa richness, Ephemeroptera taxa richness, Plecoptera taxa richness, Trichoptera taxa richness, Diptera taxa richness, Odonata taxa richness, and Coleoptera taxa richness (Stribling et al. 1998). Compositional metrics included: \% EPT, \% Baetidae of Ephemeroptera, \% Chironomidae of Diptera, overall \% Chironomidae, \% Ephemeroptera, \% Trichoptera, \% Plecoptera, \% Odonata, \% Coleoptera, \% Diptera, \% Oligochaeta, \% non-insect, \% Amphipoda, \% Hydropsychidae of Trichoptera, \% swimmer, \% clinger, \% burrower, \% sprawler, \% collector, \% predator, \% shredder, and \% scraper (Stribling et al. 1998). Additional compositional metrics not advocated by Stribling et al. (1998), but used in this study were: \% Heptageniidae, \% Baetidae, \% Cheumatopsyche, \% climber, \% Corydalidae, \% Decapoda, \% Epeorus spp., \% Ephemeridae, \% Ephemerellidae, \% Glossosomatidae, \% Hydropsychidae, \% Leptophlebiidae, \% Leucritidae, \% Leucrocuta spp., \% Limnephilidae, \% Megaloptera, \% Peltoperlidae, \% Perlidae, \% Perlodidae, \% Philopotamidae, \% Polycentropodidae, \% Rhyacophilidae, \% Sialidae, \% Stenacron spp., and \% Stenonema spp. 
Statistical analyses

As macroinvertebrate variability is high between seasons and year, each sampling season was analyzed separately. A nested ANOVA was used to detect macroinvertebrate differences among and within streams. Using simple linear regression, each metric was compared to the percent less than each size class in the Wentworth series across the sample streams. A mean value for each metric was calculated for each sample section using habitat weighted metrics. A single numerical descriptor was generated during regression for comparison between macroinvertebrates in each stream to its level of fine sediment. Regression was performed across the streams to detect the effect of a range of sediment treatments within the survey. An arcsine square root transformation was used on metric percentage data (Krebs 1999). Metrics also were compared to habitat and water chemistry variables collected by simple linear regression. In order to reduce variability arising from comparing macroinvertebrates collected in pools to sediment collected in riffles, all metrics were retested using only macroinvertebrate samples collected in riffles compared to sediment collected in the same riffle. In each season, the Dunn-Sidak method was used to adjust the $\alpha$-level to 0.01 to reduce experiment wise error rate from performing multiple statistical analyses on the same data set during tests of metric sensitivity (Sokal and Rohlf 1995). 


\section{Results}

Macroinvertebrate differences among and within streams using combined habitat weighted data

In general, neither macroinvertebrate density nor biomass differed between streams or sites within a stream. However, in the fall of 1998, macroinvertebrate density differed between streams $(p=0.009)$, but not between sites within a stream $(p=0.5508)$. Macroinvertebrate biomass did not differ between streams $(p=0.7534)$ or sites ( $p=0.8914)$ within a stream. In the spring of 1999 , macroinvertebrate density differed between streams $(p=0.0018)$, but not between sites $(p=0.6516)$. In the fall of 1999, neither macroinvertebrate density ( $\mathrm{p}=0.2377$ (streams) and $\mathrm{p}=0.3534$ (sites)) nor biomass $(\mathrm{p}=0.2633$ (streams) and $\mathrm{p}=0.2562$ (sites)) differed between streams or sites. In the spring of 2000 , macroinvertebrate density $(p=0.2272$ (streams) and $p=0.2037$ (sites)) and biomass ( $p=0.4343$ (streams) and $p=0.2562$ (sites)) did not differ between streams and sites.

Macroinvertebrates differences between streams using only riffle data

Macroinvertebrate differences between streams and sites within a stream mirrored combined riffle and pool habitat results when pool data was excluded. In the fall of 1998 , macroinvertebrate density significantly differed among streams $(p=0.0116)$ but not reaches $(p=0.6337)$. Macroinvertebrate biomass in the fall of 1998 did not differ among streams $(p=0.5445)$ or reaches $(p=0.7161)$. In the spring of 1999 , 
macroinvertebrate density ( $\mathrm{p}=0.0578$ (streams) and $\mathrm{p}=0.4053$ (reaches)) and biomass $(p=0.5717$ (streams) and $p=0.7161$ (reaches)) did not differ among streams or reaches. In the fall of 1999 and the spring of 2000, neither macroinvertebrate density nor biomass differed significantly among streams or reaches.

\section{Stream physical habitat and water chemistry}

The seven study streams did not differ in average depth, maximum depth, or discharge in 1999 or 2000 (Table 1). Average area of a habitat unit differed in 1999 with Mullenax Run having significantly higher average area $(p=0.0056)$ than the other streams. In 2000, Mullenax Run and Elleber Run had significantly higher average areas $(p<0.0001)$ than other streams. Average area of a habitat unit was greater in 2000 than in $1999(p<0.0001)$. Slope differed between the streams $(p<0.0001)$. The slope of Poca Run (9.3\%) was significantly higher than all other streams. Little Low Place (8.0\%) and Elleber Run (7.3\%) had similar slopes as did Long Run (5.7\%) and Lick Run (4.7\%). Mullenax Run (4.0\%) had the least change in elevation of all of the streams. Little Low Place had significantly more bedrock $(p=0.0079)$ than the other streams. In 1999 and 2000, the streams differed in summer average temperature $(p<0.0001$ in both years) except for Lick Run and Long Run both of which had similar temperatures.

Water chemistry variables measured during the course of this study remained within acceptable parameters for benthic macroinvertebrates (Surber 1974) (Tables 1 and 2). In all four sampling periods, $\mathrm{pH}$ did not vary significantly between or within streams. In the summer of 1999, dissolved oxygen (mg/L) differed between streams $(p=0.0004)$ with Little Low Place having a significantly higher concentration $(\mu=7.3$ 
mg/L); Sawmill Run, Elleber Run, and Mullenax Run with similar concentrations ( $\mu=7.1$ $7.2 \mathrm{mg} / \mathrm{L})$; and the lowest concentrations in Poca Run and Lick Run $(\mu=6.2-6.9 \mathrm{mg} / \mathrm{L})$. In 1999, specific conductance was significantly different between the streams $(p<0.0001)$. Sawmill Run was significantly higher $(\mu=280)$ than the other streams. Little Low Place $(\mu=54)$ and Mullenax Run $(\mu=43)$ were significantly lower than Sawmill Run but significantly higher than the remaining streams ( $\mu=33-41)$. In 2000, dissolved oxygen did not differ between streams, but specific conductance was again significantly higher in Sawmill Run than the other streams $(\mathrm{p}<0.0001)$. Storm samples revealed Sawmill Run to have a significantly higher $\mathrm{pH}(\mathrm{p}=0.0105)$, alkalinity $(\mathrm{p}=0.0002)$, concentration of dissolved magnesium ( $p=0.0002)$, concentration of dissolved calcium $(p<0.0001)$, and Acid Neutralizing Capability (ANC) $(p<0.0001)$ during storms than the other streams.

Macroinvertebrate response to physical habitat and water chemistry

Macroinvertebrate response to habitat varied by season. In the fall of 1998, larger average area of habitat units within the sample section increased EPT taxa richness $\left(r^{2}=0.97, p=0.0004\right)$ and Plecoptera taxa richness $\left(r^{2}=0.93, p=0.0018\right)$. Metrics did not respond to habitat variables in the spring 1999, fall 1999, or spring 2000.

Metrics did not respond to measured water chemistry variables in the fall of 1998 , spring of 1999 , fall of 1999 , or spring of 2000 . Metrics did respond in the spring of 2000 to dissolved ions measured from spring 2000 storm samples (Table 2). As magnesium increased, the metric \% Coleoptera $\left(r^{2}=0.89, p=0.0014\right)$ increased. As total alkalinity increased, the metric $\%$ Coleoptera increased $\left(r^{2}=0.78, p=0.0019\right)$. With increasing 
calcium, the Ephemeroptera metric \% Baetidae $\left(r^{2}=0.97, p=0.0021\right)$ and the metric \% Coleoptera increased $\left(r^{2}=0.97, p=0.0021\right)$.

\section{Stream sediment composition}

In all four seasons, sediment composition varied significantly among streams $(p<0.0001)$ (Table 3). However, within six of the seven study streams sediment composition did not vary among seasons over the course of the study (Table 3). Elleber Run experienced elevated fine sediment $(<2 \mathrm{~mm})$ levels in the fall of 1999 following road construction the previous summer of that year. In fall 1998, spring 1999, and summer 2000, sediment $<1 \mathrm{~mm}(\mathrm{p}=0.032)$, sediment $<0.5 \mathrm{~mm}(\mathrm{p}=0.01)$, and sediment $<0.25 \mathrm{~mm}(p=0.035)$ differed among streams. Mullenax Run had significantly higher amounts of all three size classes than Poca Run. In the seven study streams, sediment $<1 \mathrm{~mm}$ ranged from $0.7 \%$ (Poca Run) to $8.4 \%$ (Mullenax Run), sediment $<0.5 \mathrm{~mm}$ ranged from $0.4 \%$ (Poca Run) to $5.5 \%$ (Mullenax Run), and sediment $<0.25 \mathrm{~mm}$ ranged from $0.3 \%$ (Poca Run) to $2.4 \%$ (Mullenax Run). In the fall of 1999 , elevated sediment levels in Elleber Run significantly differed Elleber Run from other streams in sediment $<16 \mathrm{~mm}(\mathrm{p}=0.02)$, sediment $<8 \mathrm{~mm}(\mathrm{p}=0.02)$, and sediment $<4 \mathrm{~mm}(\mathrm{p}=0.02)$. In the fall of 1999, Mullenax Run differed from the other streams in composition of sediment $<0.5$ $\mathrm{mm}(\mathrm{p}=0.05)$, and Lick Run experienced higher levels of sediment $<0.063 \mathrm{~mm}(p=0.01)$ than other study streams. 
Macroinvertebrate response to sediment sizes using combined habitat weighted metrics

The fall 1998 macroinvertebrate collection revealed several metrics which responded to the percentage of particular sizes of sediment. Three metrics, EPT taxa richness $\left(r^{2}=0.77, p=0.021\right)$, Plecoptera taxa richness $\left(r^{2}=0.69, p=0.039\right)$, and Trichoptera taxa richness $\left(r^{2}=0.98, p=0.0002\right)$ declined with increasing sediment $<0.125$ $\mathrm{mm}$ (Figure 1). The change in EPT taxarichness was not significant between the lowest sediment streams (Elleber Run, Little Low Place, Long Run, Mullenax Run, and Poca Run) but was significant $(p=0.025)$ between the group of five similar streams and the stream with the lowest EPT taxa richness (Lick Run). Taxa changes among EPTs also were noted with increasing sediment $<0.125 \mathrm{~mm}$ (Table 4). The metric \% Oligochaeta $\left(r^{2}=0.82, p=0.013\right)$ increased with increasing sediment $<0.125 \mathrm{~mm}$. The metric $\%$ noninsect increased with increasing sediment $<2 \mathrm{~mm}\left(\mathrm{r}^{2}=0.89, \mathrm{p}=0.0044\right)$.

The spring 1999 macroinvertebrate collection uncovered several other metrics responding to fine sediment. The metric $\%$ scraper $\left(r^{2}=0.86, p=0.0075\right)$ decreased with increasing proportion of sediment $<2 \mathrm{~mm}$. The metric $\%$ Oligochaeta $\left(r^{2}=0.93, p=0.008\right)$ was positively related to increasing sediment $<2 \mathrm{~mm}$. The metric $\%$ Odonata $\left(r^{2}=0.95\right.$, $p=0.0042$ ) increased with increasing percentage of fine sediment $<0.063 \mathrm{~mm}$.

Many metrics responded to fine sediment in the fall of 1999 (Table 5). The metrics EPT taxa richness (Figure 2) and Plecoptera taxa richness responded to various size classes similarly to fall 1998. The metric \% non-insect declined in fall 1999 with increasing percentages of fine sediment $<4 \mathrm{~mm}$ rather than increasing as it did in fall 1998. However, sediment sizes generating responses differed from the previous 
fall. In the fall of 1999, EPT taxa richness and Plecoptera taxa richness were negatively related to the percentage of sediment $<8 \mathrm{~mm}$ instead of sediment $<0.125 \mathrm{~mm}$ as both were in the fall of 1998 . The metric $\%$ non-insect was negatively related to the percentage of sediment $<4 \mathrm{~mm}$ in the fall of 1999 while positively related to sediment $<2$ $\mathrm{mm}$ in the fall of 1998. Following road construction in the summer of 1999, fall 1999 macroinvertebrate densities decreased in Elleber Run, although not significantly, and the \% EPT in Elleber Run also decreased compared to the previous fall $(p=0.0051)$. Due to the influence of Elleber Run to relationships between community metrics and fine sediment in 1998, reductions in \% EPT in Elleber Run in fall 1999 may have changed some patterns of macroinvertebrate response to sediment during the fall 1999 season.

In the spring of 2000 , only three metrics responded to particular sediment sizes. The metric EPT taxa richness decreased $\left(r^{2}=0.79, p=0.0071\right)$ with increasing percentage of sediment $<0.25 \mathrm{~mm}$. In the spring of 2000, Mullenax Run had the lowest EPT taxa richness and highest percentage of sediment $<0.25 \mathrm{~mm}$ unlike the fall of 1998 when Lick Run had the lowest EPT taxa richness and highest fine sediment. Ephemeroptera taxa richness declined $\left(r^{2}=0.80, p=0.0067\right)$ with increasing percentage of sediment $<0.125 \mathrm{~mm}$. Plecoptera taxa richness $\left(r^{2}=0.60, p=0.04\right)$ was negatively related to increasing percentage of sediment $<0.5 \mathrm{~mm}$. Taxa replacement from less tolerant to more sediment tolerant taxa as described in Waters (1995) with increasing fine sediment levels was not apparent in the spring of 2000 (Table 6). 
Macroinvertebrate response to sediment size using metrics from riffles only

When pool samples were excluded from analyses of the relationships between macroinvertebrates and sediment size classes, some different relationships were uncovered between macroinvertebrates and fine sediment while other relationships were strengthened (Table 7). In the fall of 1998, EPT taxa richness $\left(r^{2}=0.74, p=0.028\right)$, Trichoptera taxa richness $\left(r^{2}=0.77, p=0.023\right)$, and $\%$ collector $\left(r^{2}=0.69, p=0.04\right)$ responded negatively to increasing percentage of sediment $<0.125 \mathrm{~mm}$ (Figure 3). The Ephemeroptera metrics \% Ameletidae $\left(r^{2}=0.99, p=0.0049\right)$ and $\%$ Baetidae of Ephemeroptera $\left(r^{2}=0.87, p=0.0067\right)$ as well as the Plecoptera metric \% Perlodidae $\left(r^{2}=0.90, p=0.0041\right)$ and the functional group $\%$ scraper $\left(r^{2}=0.73, p=0.04\right)$ responded positively to increasing proportion of sediment $<0.125 \mathrm{~mm}$ (Figure 4). The Ephemeroptera metric \% Ephemerellidae $\left(r^{2}=0.73, p=0.03\right)$ and the Trichoptera metric $\%$ Hydropsychidae $\left(r^{2}=0.70, p=0.039\right)$ increased with increasing sediment $<0.25 \mathrm{~mm}$. The metric $\%$ Chironomidae of Diptera responded negatively $\left(r^{2}=0.69, p=0.04\right)$ to increasing sediment $<1 \mathrm{~mm}$. The smallest sediment class, $<0.063 \mathrm{~mm}$, generated a positive response in the Plecoptera metric \% Leuctridae $\left(r^{2}=0.69, p=0.041\right)$.

In the spring of 1999 , several additional metrics demonstrated sensitivity to fine sediment that did not show significant relationships with pool data included. Furthermore, two metrics, \% Oligochaeta and \% Odonata, that demonstrated significance when pool habitat was included did not have any significance when pool data was excluded. However, the metrics $\%$ Trichoptera $\left(r^{2}=0.94, p=0.033\right)$ and $\%$ Polycentropodidae $\left(r^{2}=0.91, p=0.048\right)$ were positively related to increasing percentage 
of sediment $<1 \mathrm{~mm}$ (Figure 5). The Plecoptera metric \% Chloroperlidae was negatively related $\left(r^{2}=0.92, p=0.039\right)$ to increasing sediment $<1 \mathrm{~mm}$. The metric $\%$ clinger declined $\left(r^{2}=0.96, p=0.022\right)$ with increasing sediment $<2 \mathrm{~mm}$. Sediment $<0.125 \mathrm{~mm}$, implicated in many sediment-macroinvertebrate relationships in the fall of 1998, was negatively related to $\%$ non-insect $\left(r^{2}=0.99, p=0.007\right)$ (Figure 6).

The exclusion of pool data reduced the number of metrics that responded to fine sediment sizes in fall 1999. Two metrics, Plecoptera taxa richness $\left(r^{2}=0.77, p=0.021\right)$ and Trichoptera taxa richness $\left(r^{2}=0.67, p=0.024\right)$ were positively related to increasing fine sediment percentages $<0.125 \mathrm{~mm}$. Only one other metric, \% Hydropsychidae of Trichoptera, was positively related $\left(r^{2}=0.685, p=0.0215\right)$ to sediment $<1 \mathrm{~mm}$.

In the spring of 2000 , omitting pool data increased the number of metrics responding to increasing fine sediment. Two metrics, taxa EPT richness and Ephemeroptera taxa richness, were related to the same sediment size classes without pool data as they were with pool data included. Using only riffle data, EPT taxa richness was negatively related $\left(r^{2}=0.62, p=0.035\right)$ to increasing percentages of fine sediment $<0.25 \mathrm{~mm}$. Ephemeroptera taxa richness was negatively related $\left(r^{2}=0.63\right.$, $p=0.034$ ) to increasing fine sediment $<0.125 \mathrm{~mm}$. The metric \% Hydropsychidae of Trichoptera was positively related $\left(r^{2}=0.72, p=0.016\right)$ to increasing sediment $<0.063$ $\mathrm{mm}$. Increasing fine sediment $<8 \mathrm{~mm}$ was positively related $\left(\mathrm{r}^{2}=0.65, \mathrm{p}=0.029\right)$ to $\%$ Baetidae of Ephemeroptera, but negatively related $\left(r^{2}=0.57, p=0.049\right)$ to $\%$ Heptageniidae. The metric $\%$ swimmer increased $\left(r^{2}=0.59, p=0.045\right)$ with increasing fine sediment $<4 \mathrm{~mm}$. 
Macroinvertebrate response to fine sediment amounts

Our expectations about macroinvertebrate response to fine sediment amounts in the streams was based upon the presumption the streams selected for the study would encompass a wide enough range of sedimentation levels that significant declines in abundance or diversity could be noted in response to a higher level of fine sediment. However, with the tremendous seasonal and annual variability in the data, only a few inferences could be made regarding amounts of fine sediment that trigger a precipitous decline in abundance or diversity. The only clear picture concerning declines in taxonomic diversity, and thus changes in community structure, was observed in EPT taxa richness in the fall of 1998 (Figure 1). Five of the six streams were not significantly different in mean number of EPT genera per sample. However, the sixth stream (Lick Run) was significantly different $(p<0.0001)$ than the group of five streams and had the highest \% fine sediment $<0.125 \mathrm{~mm}$ with the lowest mean number of EPT genera per sample. The decline in EPT taxa richness occurred when the \% fine sediment $<0.125 \mathrm{~mm}$ exceeded $0.8 \%$ of the substrate in 1998 . The $\%$ fine sediment $<0.125 \mathrm{~mm}$ was $1.21 \%$ in Lick Run in 1998; therefore, declines in EPT taxa richness occurred between $0.8-1.21 \%$ of the substrate. Similar declines at approximately the same amount of fine sediment occurred in the spring of 2000 (Figure 7). Mean number of EPT genera declined from 12 genera (Sawmill Run, $0.9 \%$ fine sediment $<0.25 \mathrm{~mm}$ ) to 9 genera (Mullenax Run, 2.27\% fine sediment $<0.25 \mathrm{~mm}$ ). In both years, declines occurred when fine sediment exceeded some threshold level greater than $0.8 \%$ (1998) or $0.9 \%$ (2000). 


\section{Discussion}

Multiple environmental factors influenced macroinvertebrate communities during the two years of stream surveys. Seasonal and yearly variation combined with these disturbances to complicate the detection of the relationships between perturbation and response. Yet, relationships were detected between temperature, water chemistry, habitat, fine sediment, and drought with macroinvertebrate community metrics.

Several events occurred during the course of this study that suggest a hierarchical nature of increasingly strong perturbations and responses may have complicated the detection of relationships between environmental factors and macroinvertebrate response. One of the best examples of one perturbation overwhelming the effects of another environmental factor was observed in Elleber Run in the fall of 1999. An extensive culvert replacement operation occurred in Elleber Run in the summer of 1999. Prior to road repair, Elleber Run consistently exhibited low levels of fine sediment, high quality of habitat, excellent water quality, and an abundant and diverse macroinvertebrate community (Tables 3 and 7). Fine sediment levels in Elleber Run significantly increased and macroinvertebrate abundance and diversity declined in the two seasons following culvert replacement. A drought in the region in 1999 further complicated the situation. However, drought should affect similar streams in a given region in a consistent manner (Del Rosario and Resh 2000). All of the streams experienced a reduction in macroinvertebrate density and diversity following the drought. The reduction in density and diversity was more pronounced in Elleber Run possibly suggesting increasing fine sediment from culvert replacement was a more 
potent influence on macroinvertebrates than the positive influences of excellent water quality since Elleber Run fared worse than could be attributed to the drought.

Furthermore, Mullenax Run consistently exhibited one of the highest summer average temperatures. Mullenax Run also contained one of the most diverse and abundant macroinvertebrate communities in the first two sampling periods. However, macroinvertebrate density and diversity declined in Mullenax Run over the course of the study as fine sediment increased. Furthermore, Little Low Place and Poca Run consistently exhibited excellent water quality and low levels of fine sediment, but both streams exhibited a decline in macroinvertebrate density and diversity following the drought despite a lack of detectable changes in habitat or water quality. It appears that excess fine sediment can overwhelm excellent water quality, but drought was a more powerful perturbation than excess fine sediment.

Water temperature and chemistry appeared to play a lesser role than other potential influences in the composition of macroinvertebrate communities in the study streams. These streams were selected for similarity in temperature and water chemistry, but with different substrate compositions. Strong relationships between macroinvertebrates and water temperature and chemistry were not expected in these streams. Only \% Ephemeridae responded to water temperature in the fall of 1999. Macroinvertebrate metrics did not respond to $\mathrm{pH}$ or specific conductance within the streams. The range of $\mathrm{pH}$ and specific conductance, with the exception of specific conductance in Sawmill Run, was narrow in the streams. The only detectable relationship between metrics and water chemistry was dissolved metals. Several macroinvertebrate metrics responded to increasing dissolved metals. However, 
relationships between metrics and metals may be misleading in this case. In studies investigating mine drainage, strong relationships between zinc, copper, and cadmium were reported to influence macroinvertebrate communities (Clements and Kiffney 1995; Kiffney and Clements 1996; Kiffney 1996). As well, studies in Ontario springs revealed dissolved metals to structure macroinvertebrate communities (Williams et al. 1997). However, in the underlying geology of the study streams, aluminum was the major dissolved metal. Yet, relationships between aluminum and macroinvertebrates in the study streams may not actually be relevant. Metals were only sampled once and during a seasonal period of relatively low abundance and diversity within the streams. Furthermore, relationships between metals and macroinvertebrates possibly were complicated by the relic effects of the drought in late 1999. Relic effects of the drought also may have caused a water temperature effect that was not present in non-drought seasons. Therefore, the relationships between temperature and metals with macroinvertebrate metrics were probably not as important as other environmental factors at work in the streams.

The nature and availability of habitat types was certainly an important determinant in macroinvertebrate community structure. Again, the streams included in this study were selected for similarity in environmental variables with differences restricted to substrate composition. Strong relationships between macroinvertebrates and habitat were envisioned only to assist in determination of the effects of fine sediment by accounting for any differences from varying habitat. Indeed, macroinvertebrate response in the pre-drought sample season corroborated the typical relationships between habitat and macroinvertebrates. In the fall of 1998 , 
macroinvertebrate metrics responded positively to increasing average area of habitat (pool or riffle versus exposed bedrock). However, in seasons of lower abundance and reduced taxonomic diversity (spring 1999) and seasons post-drought (fall 1999 and spring 2000), these relationships were not apparent. The lack of normal macroinvertebrate-habitat relationships suggests a serious disruption of the macroinvertebrate community due to the drought.

The drought strongly influenced metric responses in the fall of 1999 and spring of 2000. Lake (2000) describes a drought as a ramp disturbance with increasing effects over time. The cessation of the drought does not bring immediate recovery. Instead, recovery from drought takes considerable time (Lake 2000). A press disturbance increases to a certain level (e.g. road construction) and remains at or near that level indefinitely (e.g. road runoff) (Lake 2000). It was very likely that the effects of the drought increased in the pattern of a ramp disturbance until these effects overwhelmed the influence of a less powerful press disturbance from fine sediment. The inconsistencies in response patterns, such as a change in direction of response, of benthic macroinvertebrate metrics suggest the drought may have overshadowed the effects of fine sediment in the fall of 1999 and spring of 2000 despite heavier than average precipitation during those periods.

The drought appeared to elicit inconsistencies in macroinvertebrate response to excess fine sediment. The metric \% non-insect decreased rather than increased with increasing fine sediment in the fall of 1999 . This type of reversal was noted only in $\%$ non-insect. This may be reflective of movement of non-insects toward larger substrate particles driven by water receding from the stream bank during the drought. Larger 
sediment classes tended to concentrate in the main channel of the streams while smaller size classes tended to be found at the stream margins (Luepold et al. 1964; Swanston 1991). Macroinvertebrate taxa following the receding stream margins would appear to favor larger size particles while actually seeking watered sections of the stream. Movement of taxa from unwatered to watered portions of the stream also may explain the apparent negative response to larger $(8$ and $4 \mathrm{~mm})$ substrate particles observed in some metrics. The responses of EPT and Plecoptera taxa richness appeared to show an avoidance of particles less than $8 \mathrm{~mm}$. However, it was more likely these macroinvertebrates were selecting microhabitats in the center of the channel where the largest $(>8 \mathrm{~mm}$ ) substrate was found based on water availability rather than substrate size.

Some metric responses in the fall of 1999 were more likely a reflection of the conditions favoring pool habitat and taxa tolerant of lower flows. As the streams dried, some riffle sections became trickles with little flow between the pools. Pools did not decline as dramatically as riffles. Ephemeridae, a burrowing Ephemeropteran, exhibited a positive response to fine sediment. This may be a reflection of declines in riffle macroinvertebrates in favor of facultative pool macroinvertebrates such as Ephemeridae (Edmunds and Waltz 1996). The same may be said of Limnephilidae, Perlodidae, Philopotamidae, and Polycentropodidae which also may make use of pool habitat. (Stewart and Harper 1996; Wiggins 1998). Declines in Leucrocuta spp. (Ephemeroptera: Heptageniidae) were more likely a response to declining riffle habitat than fine sediment sizes within the substrate. Even during the driest period of the summer, none of the streams experienced an interruption in flow, although flows in Lick 
run sometimes remained within the benthic gravel in one small portion. Water was available to macroinvertebrates in some portions of the stream. Dissolved oxygen levels, $\mathrm{pH}$, or temperature did not appear to lethal levels at any time during the summer of 1999 (Surber 1974). Any one, or combination of, reduced flow and/or overall reduction in macroinvertebrate scenarios may have influenced metrics more than sediment size class during the fall of 1999.

Therefore, interpretations of macroinvertebrate responses in the fall of 1999 were difficult. Some light was shed on the relevance of particular macroinvertebrate responses from a concurrent experiment (see Chapter 2) on Mullenax Run that ran for 5 weeks during the dry period. This experiment tested macroinvertebrate response to increasing fine sediment $(<2 \mathrm{~mm})$ treatments in one stream. The uniformity of environmental variables within the stream forced macroinvertebrates to respond to sediment treatments (Chapter 2). Although low water conditions plagued this experiment as well, similar regressions performed against sediment size classes revealed declines in EPT taxa richness $(p=0.0031)$ and increases in \% climber $(p=0.0019)$ to increases in sediment less than $2 \mathrm{~mm}$ even in low water conditions (Chapter 2). Therefore, the declines observed in EPT taxa richness in the fall of 1999 may be meaningful as this metric demonstrated resilience against low water conditions in a single stream sediment experiment (Chapter 2).

In some lotic systems, including some in West Virginia, the hyporheos has been hypothesized as a refuge for benthic macroinvertebrates during dry periods (Williams and Hynes 1974; Griffith and Perry 1993). Yet, in other systems, the hyporheos does not serve as a refuge for benthic macroinvertebrates during dry periods (Bolton et al. 
1992; Del Rosario and Resh 2000). Unfortunately, an in depth investigation of the hyporheos was beyond the scope of this project. However, Angradi et al. (in press) found the hyporheos in the nearby Fernow experimental forest to harbor abundant and diverse macroinvertebrate community. Therefore, conclusive evidence concerning a hyporheic refuge in these streams does not exist.

The original focus of this research was upon the relationships between macroinvertebrate metrics and fine sediment. Of course, other environmental variables have an effect upon macroinvertebrates adding confounding variability to the detection of specific relationships between macroinvertebrate metrics and fine sediment. Given that streams in this study were selected for similarity in as many environmental qualities as possible, the detection of the influence of fine sediment should have been readily apparent had it not been for the drought. As fine sediment overwhelmed the positive effects of habitat and water chemistry in Elleber Run, drought appeared to be a more potent disturbance than fine sediment in the study streams. In each case, a stronger perturbation initiated a different response pattern from the macroinvertebrates. However, the water years 1998 and 2000 were very similar to the 30 year average for the region (NOAA/NCDC 1999, 2000). Therefore, the fall of 1998 can be considered representative of "normal" stream conditions given the similarity in other measured environmental variables. Furthermore, patterns of macroinvertebrate response in the spring of 2000 echo the patterns detected in the fall of 1998 indicating recovery from the drought may have been occurring as early as the winter of 1999/2000. Therefore, relationships between fine sediment and macroinvertebrates that demonstrated 
consistency in seasons not influenced by the drought probably have the greatest applicability to future biomonitoring.

Relationships between benthic macroinvertebrate metrics and fine sediment particle classes varied among year and season (Table 7). The metrics EPT taxa richness, Plecoptera taxa richness, \% non-insect, and \% Oligochaeta responded negatively to fine sediment particle sizes in several seasons. This was consistent with previous observations concerning macroinvertebrate taxa declines in response to the sand (typically 2.0-0.05 $\mathrm{mm}$ ) and silt (typically $0.5-0.002 \mathrm{~mm}$ ) sedimentation within streams (Tebo 1955; Sandine 1974; Luedtke and Brusven 1976; Rosenberg and Wiens 1978; Quinn and Hickey 1990; Richards and Bacon 1994; Waters 1995; Rier and King 1996; Vouri and Joensuu 1996). Serious comparison to these studies is hampered by differences in sediment size assessment between these studies and sediment collected in this and other recent Appalachian studies (Angradi 1999; Chapter 2). However, the increases and declines of these metrics suggest changes in community structure in response to increasing amounts of fine sediment particles in the substrate.

Macroinvertebrate taxa responded differently to different size classes within the sand $(2.0-0.125 \mathrm{~mm})$ substrate size class. We collected macroinvertebrates and sediment with similar methods to Angradi (1999) with similar results (Chapter 2) (Table 8). These relationships suggest attention should be paid to finer size classes within the sand substrate size class. The macroinvertebrate community may be structured by particular size classes within the sand or smaller categories that may be related back to a particular type of perturbation known to generate different sediment sizes for identification of the particular source of sedimentation. 
The exclusion of pool samples in testing relationships between benthic macroinvertebrate metrics did not reduce the tremendous seasonal and yearly variability in response (Table 7). Drought also appeared to influence the response of macroinvertebrates in riffles alone. However, the exclusion of pool samples did corroborate some relationships observed with combined habitat data as well as uncovering other predictable relationships that may have been masked by the pool data.

Analyses of riffle data alone also demonstrated some relationships not apparent using combined habitat data (Table 7). The most numerous differences between the analysis of the combined habitat data and the analysis of exclusively riffle data were in the fall of 1998. Taxonomic diversity was highest in the fall of 1998 compared to the following spring and was higher even the fall of 1999 compared to the following spring despite the immediate (fall 1999) and long-term (spring 2000) effects of the drought of 1999.

The interpretation of the responses occurring only in riffle habitat lends further credence that sediment may be the most important community structuring component in these streams when all other environmental factors are similar. Several results from the fall of 1998 were consistent with reported results from the literature. A positive relationship between increasing fine sediment and \% Baetidae of Ephemeroptera was also noted in sediment experiments in West Virginia by Angradi (1999). Angradi (1999) also reported a negative relationship between some Chironomid sub-families and fine sediment. The negative relationship observed in the stream surveys may have been caused by these Chironomid sub-families. Identification of Chironomidae below the 
family-level was judged too time consuming for the purposes of this study; therefore, it is only speculation that the same sub-families were influencing the response of $\%$ Chironomidae in this study. A positive relationship between fine sediment less than $0.063 \mathrm{~mm}$ and \% Leucritidae is not surprising given the evidence of burrowing by Leuctrids in the literature (Stewart and Stark 1988; Angradi et al. (in press)). A positive response by \% Ephemeridae to fine sediment is consistent with their burrowing lifestyle (Edmunds and Waltz 1996). The performance of these metrics consistent with the literature suggests the validity of testing metrics against \% less than fine sediment with linear regression. If the metrics failed to corroborate literature predictions, it may suggest fine sediment is not a major influence of macroinvertebrate populations. Since the relationships between these metrics matched literature predictions based on known aspects of the life history of the taxa represented by the metrics, it appears fine sediment may be the most important predictor of these taxonomic groups. Furthermore, since metric analyses using riffle data only uncovered results consistent with literature predictions, it increases the likelihood other results, perhaps not as strongly supported in the literature, were valid.

Discussion of macroinvertebrate response to specific increasing amounts of fine sediment is restricted to declines in EPT richness in the fall of 1998 and spring of 2000 with increases in fine sediment $<0.125 \mathrm{~mm}$ and $0.25 \mathrm{~mm}$ respectively (Figure 7 ). When sediment $<0.125 \mathrm{~mm}$ exceeded $0.8 \%$ of the substrate in the fall of 1998 , EPT genera significantly declined $(p<0.0001)$ from 34 genera per sample to 15 genera per sample (Table 4). In fall 1998, several genera: Ameletus spp. (Ephemeroptera: Ameletidae), Drunella spp. (Ephemeroptera: Ephemerellidae), Seratella spp. (Ephemeroptera: 
Ephemerellidae) and Perlesta spp. (Plecoptera: Perlidae) were not found in macroinvertebrate communities with sediment less than $0.125 \mathrm{~mm}$ exceeding $0.64 \%$ of the substrate. The entire family Heptageniidae (Ephemeroptera) was absent in the highest level (1.21\%) of $0.125 \mathrm{~mm}$ in the study streams. In the summer of 2000 , EPT genera declined from 12 genera per sample to 10 genera per sample when sediment $<0.125 \mathrm{~mm}$ exceeded $0.9 \%$ of the substrate. Angradi (1999) also noted EPT taxa declines resulting from increasing fine sediment that were subtle ( 3 taxa) in the summer of 1996 in West Virginia streams. It did not appear to matter which stream had excess fine sediment. In the fall of 1998, Lick Run experienced the highest fine sediment in these size classes and the lowest EPT taxa richness. By the spring of 2000, sedimentation regimes had changed, and Mullenax Run exceeded the threshold and exhibited the lowest EPT taxa richness (Table 6). Detection of taxa reduction in multiple seasons despite a possible sampling bias yields further evidence of declines in the EPT metric to specific fine sediment amounts ( $>0.9 \%$ ) of fine sediment less than $0.25-0.125$ $\mathrm{mm}$ in forested northern Appalachian streams.

Summary of macroinvertebrates responses to sizes and amounts of fine sediment With consistent responses by macroinvertebrates to narrow ranges of fine sediment sizes, future investigations should focus on these sediment classes to identify their sources and to enact remediation efforts. It is likely different physiographic regions will require additional research to detect the sensitivity of the macroinvertebrates of that region to excess fine sedimentation. EPT taxa richness and Plecoptera taxa richness responded to a narrow range of sediment size classes from less than $0.25-0.125 \mathrm{~mm}$ 
size classes and 0.5-0.125 mm size classes respectively over two seasons. When these size classes exceeded approximately $0.9 \%$ of the substrate, EPT taxa declined significantly across the streams. Related metrics: \% scraper; Trichoptera taxa richness; and Ephemeroptera taxa richness need further investigation to develop a more consistent range of sediment size classes in more seasons. With continued testing, an empirical database could generate a suite of metrics to identify the source of sedimentation based on size class relationships. A suite of taxa are already known in their tolerance or intolerance of acidity (Stribling et al.1998). In the same manner, a suite of sensitive taxa, and therefore, metrics, could be generated for sediment as was done for sensitivity to $\mathrm{pH}$.

Extreme reductions in EPT taxa interrupt trophic processing with deleterious effects to trophic cascades within the stream and the stream network (Vannote et al 1980; Thorp and Covich 1991). In this study, excessive fine sediment reduced overall taxa diversity among Ephemeroptera, Plecoptera, and Trichoptera, in particular, scrapers and collectors. Shredders remained within the macroinvertebrate community although with reduced diversity. Fine sediment was probably coating larger substrate reducing already limited periphyton availability and inhibiting scrapers, while simultaneously coating CPOM in the furthest upstream habitats where water velocities may not have been sufficient to pass the fine sediment downstream (Vouri and Joensuu 1996; Rier and King 1996).

This study suggests that if fine sediment $(<0.25-0.125 \mathrm{~mm})$ exceeds approximately $0.9 \%$ of the substrate, taxa richness among Ephemeroptera, Plecoptera, and Trichoptera declines. This study also proposes the EPT metric as the most reliable 
metric to detect the declines in richness caused by fine sediment in these Appalachian streams. Land managers should make use of EPT taxa richness as a method of bioassessment in conjunction with sedimentation monitoring to prevent interruptions in trophic processing within streams as a result of land use practices. In conclusion, fine sediment is an important determinant of macroinvertebrate community structure in forested Appalachian streams.

\section{Acknowledgements}

The authors thank West Virginia University, the United States Department of Agriculture Forest Service, the United States Department of Agriculture MacIntireStennis program, and Westvaco Corporation for funding this project. John Sweka and William Thayne provided statistical assistance. Field assistance was provided by Matthew Sipe, Randy Cook, Amy Patsos, and Doug Wegman. Matt Evix, Chris Dobony, Mary Huff, Pat Green, Lisa Kendall, and Randy Cook assisted in the lab. Helpful inputs regarding sampling and processing were provided by Janet Clayton of the West Virginia Department of Natural Resources and J. Todd Petty of West Virginia University. Steven Harris of Clarion University examined some Trichopteran larvae from this project. Outstanding contributions to this project were made in planning, the lab, and field by Ted Angradi, Charles Sizemore, John W. Howell, and, especially, James Hakala. 


\section{Literature Cited}

Angradi, T. R., Hood, R., and D. Tarter. Accepted. Vertical, longitudinal, and temporal variation in the macrobenthos of an Appalachian headwater stream system. American Midland Naturalist. In press.

Angradi, T. R. 1999. Fine sediment and macroinvertebrate assemblages in Appalachain streams: a field experiment with biomonitoring applications. J. N. Am. Benthol. Soc. 18:43-65.

Benke, A. C., Huryn, A. D., Smock, L. A., and J. B. Wallace. 1999. Length-mass relationships for freshwater macroinvertebrates in North America with particular reference to the southeastern United States. J. N. Am. Benthol. Soc. 18:308-343.

Bilby, R. E., Sullivan, K., and S. H. Duncan. 1989. The generation and fate of roadsurface sediment in forested watersheds in southwestern Washington (USA). Forest Science 35:453-468.

Bouton, A. J., Peterson, C. G., Grimm, N. B., and S. G. Fisher. 1992. Stability of an aquatic macroinvertebrate community in a multiyear hydrologic disturbance regime. Ecology 73: 2192-2207.

Clements, W. H. and P. M. Kiffney. 1995. The influence of elevation on benthic macroinvertebrate community response to heavy metals in Rocky Mountain streams. Can. J. Fish. Aquat. Sci. 52:1966-1977.

Constantini, A., Loch, R. J., Connolly, R. D., and R. Garthe. 1999. Sediment generation from forest roads: Bed and eroded sediment size distributions, and runoff management strategies. Australian Journal of Soil Research 37:947-964.

Cummins, K. W. 1962. An evaluation of some techniques for the collection and analysis of benthic samples with special emphasis on lotic waters. American Midland Naturalist 67:477-504.

Cummins, K. W. and R. W. Merritt. 1996. Ecology and distribution of aquatic insects. Pages 74-86. In An Introduction to the Aquatic Insects of North America ( $3^{\text {rd }} \mathrm{ed}$ ). Merritt, R. W. and K. W. Cummins, Eds. Kendall/Hunt Publishing Company. Dubuque, lowa.

DelRosario, R. B. and V. H. Resh. 2000. Invertebrates in intermittent and perennial streams: is the hyporheic zone a refuge from drying? J. N. Am. Benthol. Soc.19:680696.

Edmunds, G. F. and R. D. Waltz. 1996. Ephemeroptera. Pages 126-163. In An Introduction to the Aquatic Insects of North America ( ${ }^{\text {rd }}$ ed.) Merritt, R. W. and K. W. Cummins, Eds. Kendall/Hunt Publishing Company. Dubuque, lowa. 
Feminella, J. W. 1996. Comparison of benthic macroinvertebrate assemblages in small streams along a gradient of flow permanence. J. N. Am. Benthol. Soc. 15:651-669.

Furniss, M. J., Roelefs, T. D., and C. S. Yee. 1991. Road construction and maintenance. American Fisheries Society Special Publication 19:297-323.

Gardner, R. B. 1979. Some environmental and economic effects of alternative forest road designs. Transactions of the ASAE 22:63-68.

Griffith, M. B. and S. A. Perry. 1993. The distribution of macroinvertebrates in the hyporheic zone of two small Appalachian headwater streams. Achiv fur Hydrobiologia 126:373-384.

Grost, R.T., Hubert, W.A., and T.A. Wesche. 1991. Field comparison of three devices used to sample substrate in small streams. North American Journal of Fisheries Management 11: 347-351.

Grubaugh, J. W., Wallace, J. B., and E. S. Houston. 1996. Longitudinal changes of macroinvertebrate communities along an Appalachian stream continuum. Can. J. Fish. Aquat. Sci. 53:896-909.

Hakala, J. P. 2000. Factors influencing brook trout (Salvelinus fontinalis) abundance in forested headwater Appalachian streams with emphasis on fine sediment. West Virginia University. M.S. Thesis.

Harding, J. S., Benfield, E. F., Bolstad, P. V., Helfman, G. S., and E. B. D. Jones III. 1998. Stream biodiversity: the ghost of land use past. Proc. Nat. Acad. Sci. 95:1484314847.

Hankin, D. G. and G. H. Reeves. 1988. Estimating total fish abundance and total habitat area in small streams based on visual estimation methods. Can. J. Fish Aquat. Sci. 45:834-844.

Lake, P. S. 2000. Disturbance, patchiness, and diversity in streams. J. N. Am. Benthol. Soc. 19:573-592.

Lamberti, G. A. and M. Berg. 1995. Invertebrates and other benthic features as indicators of environmental change in Juday Creek, Indiana. Natural Areas Journal 15:249-258.

Leopold, L. B., Wolman, M. G., and J. P. Miller. 1964. Fluvial processes in geomorphology. Dover Publications. Mineola, New York.

Luedtke, R. J. and M. A. Brusven. 1976. Effects of sand sedimentation on colonization of stream insects. J. Fish. Res. Board. Can. 33:1881-1886. 
Karr, J. R. and E. W. Chu. 1999. Restoring life in running waters: Better biological monitoring. Island Press. Washington, D. C.

Kiffney, P. M. 1996. Main and interactive effects of invertebrate density, predation, and metals on a Rocky Mountain stream macroinvertebrate community. Can. J. Fish. Aquat. Sci. 53:1595-1601.

Kiffney, P. M. and W. H. Clements. 1996. Size-dependent response of macroinvertebrates to metals in experimental streams. Environmental Toxicology and Chemistry 15:1352-1356.

Kochenderfer, J. N., Edwards, P. J., and F. Wood. 1997. Hydrologic impacts of logging an Appalachian watershed using West Virginia's Best Management Practices. Northern Journal of Applied Forestry 14:207-218.

Krebs, C. J. 1999. Ecological Methodology. Benjamin/Cummings. Menlo Park, California.

McMahon, T. E., Zale, A. V., and D. J. Orth. 1996. Aquatic habitat measurements. Pages 83-115. In Fisheries Techniques, $2^{\text {nd }}$ edition. Murphy, B. R., and D. W. Willis, Eds. American Fisheries Society, Bethseda, MD.

Merritt, R. W. and K.W. Cummins. 1996. An introduction to the aquatic insects of North America $3^{\text {rd }}$ ed. Kendall Hunt Publishing Company. Dubuque, lowa.

Nelson, R. L., McHenry, M. L., and W. S. Platts. 1991. Mining. In Influences of forest and rangeland management on salmonids and their habitats. Meehan, W. R., ed. Special Publication 19, American Fisheries Society. Bethseda, Maryland.

NOAA/NCDC 1999, 2000. Data provided by the National Oceanic and Atmospheric Administration's National Climate Data Center.

Peckarsky, B. L., Fraissinet, P. R., Penton, M. A., and D. J. Conklin, Jr. 1990. Freshwater macroinvertebrates of northeastern North America. Comstock Publishing Associates. Ithaca, New York.

Quinn, J. M. and C. W. Hickey. 1990. Magnitude of effects of substrate particle size, recent flooding, and catchment development on benthic invertebrates in $88 \mathrm{New}$ Zealand rivers. New Zealand Journal of Marine and Freshwater Research 24:411-427.

Rier, S. T. and D. K. King. 1996. Effects of inorganic sedimentation and riparian clearing on benthic community metabolism in an agriculturally-disturbed system. Hydrobiologia 339:111-121. 
Richards, C. and K. L. Bacon. 1994. Influence of fine sediment on macroinvertebrate colonization of surface and hyporheic stream substrates. Great Basin Naturalist 54:106113.

Rosenberg, D. M., and A. P. Wiens. 1978. Effects of sediment addition on macroinvertebrates in a northern Canadian river. Water Research 12:753-761.

Sandine, M. E. 1974. Natural and simulated insect-substrate relationships in Idaho Batholith streams. University of Idaho. M.S. thesis.

Sokal, R. R. and F. J. Rohlf. 1995. Biometry, $3^{\text {rd }}$ ed. W. H. Freeman and Company, USA.

Stewart, K. W. and P. P. Harper. 1996. Plecoptera. Pages 217-261. In An Introduction to the Aquatic Insects of North America ( $3^{\text {rd }}$ ed.) Merritt, R. W. and K. W. Cummins, Eds. Kendall/Hunt Publishing Company. Dubuque, lowa.

Stewart, K. W., and B. P. Stark. 1988. Nymphs of North American stonefly genera (Plecoptera). Entomological Society of America. College Park, Maryland.

Stribling, J. B., Jessup, B. K., and J. S. White. 1998. Development of a Benthic Index of Biotic Integrity for Maryland Streams. Chesapeake Bay and Watershed Programs Monitoring and Non-tidal Assessment. CBWP-MANTA-EA-98-3.

Surber, E. W. 1974. Minimum oxygen levels survived by aquatic macroinvertebrates. Bulletin of the Water Resources Research Center. Virginia Water Resources Center, Virginia Polytechnic Institute and State University. Blacksburg, VA.

Swanston, D. N. 1991. Natural processes. American Fisheries Society Special Publication 19:139-179.

Tebo, L. B. 1955. Effect of siltation, resulting from improper logging, on bottom fauna of a small trout stream in the Appalachians. Progressive Fish-Culturist 17:64-70.

Thorp, J. H. and A. P. Covich. 1991. An overview of freshwater habitats. Pages 17-36. In Ecology and Classification of North American Freshwater Invertebrates. Thorp, J. H. and A. P. Covich, Eds. Academic Press, Inc. San Diego, California.

Vannote, R. L., Minshall, G. W., Cummins, K. W., Sedell, J.R., and C. E. Cushing. 1980. The river continuum concept. Can. J. Fish. Aquat. Sci. 45:1123-1144.

Vouri, K. and I. Joensuu. 1996. Impact of forest drainage on the macroinvertebrates of a small boreal headwater stream: Do buffer zones protect lotic biodiversity? Biological Conservation 77:87-95. 
Ward, S. M., Taylor, B. C., and G. R. Crosby. 2000. Water resources data, West Virginia, water year 1999: United States Geological Survey Water-Data Report WV_99_1.

Waters, T. F. 1995. Sediment in streams: sources, biological effects, and controls. American Fisheries Society Monograph 7.

Wiggins, G. B. 1998. Larvae of the North American caddisfly genera $\left(2^{\text {nd }}\right.$ ed $)$. University of Toronto Press. Toronto, Ontario.

Williams, D. B. and H. B. N. Hynes. 1974. The occurrence of benthos deep in the substratum of a stream. Freshwater Biology 4:233-256.

Williams, D. D., Williams, N. E., and Y. Cao. 1997. Spatial differences in macroinvertebrate community structure in springs in southeastern Ontario in relation to their chemical and physical environments. Can. J. Zool. 75:1404-1414. 

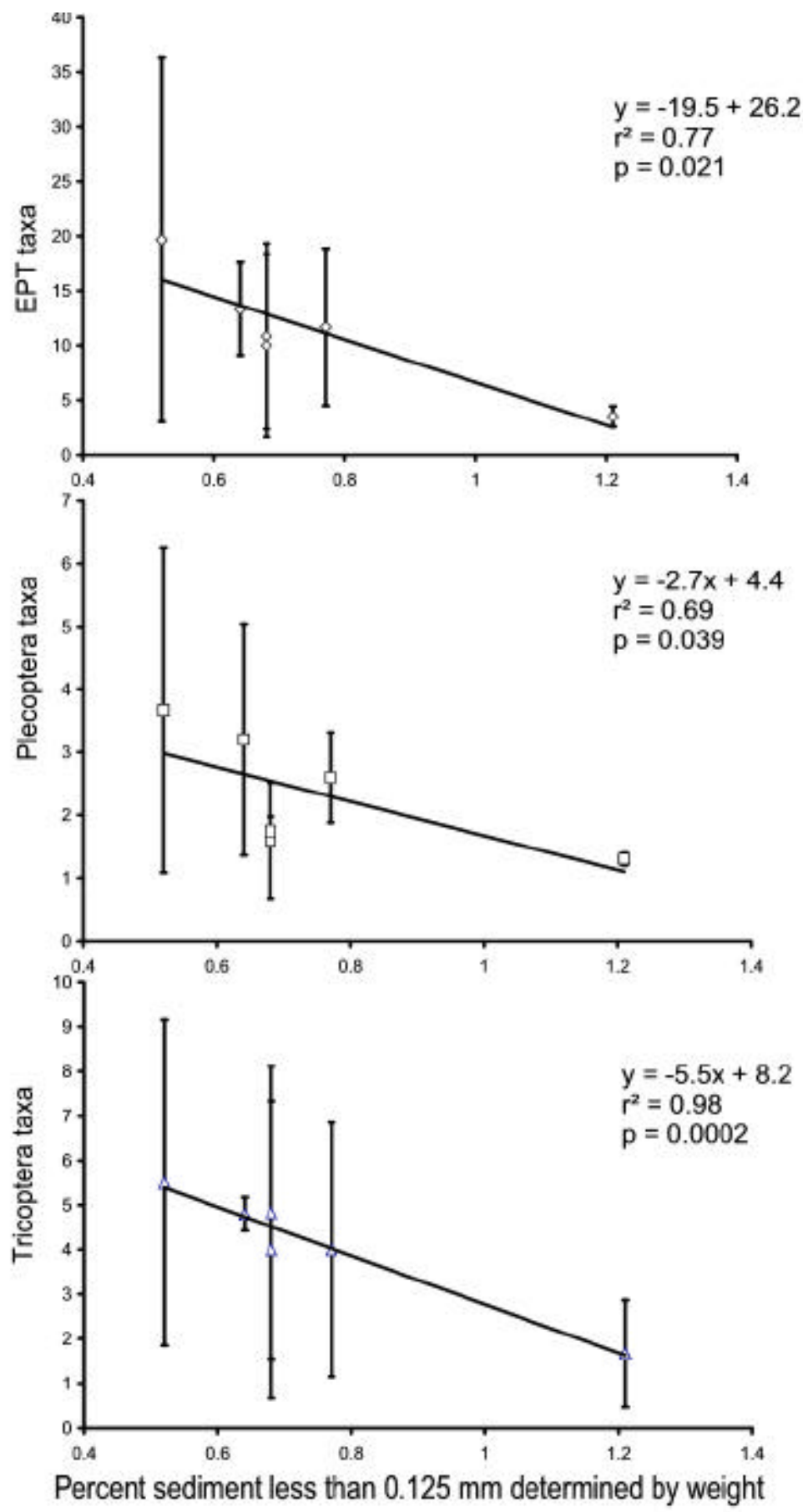

Figure 1. Declines in EPT taxa richness, Trichoptera taxa richness, and Plecoptera taxa richness in response to increasing fine sediment $<0.125 \mathrm{~mm}$ in the fall of 1998 . Values are expressed in mean number of genera per sample in each stream. Error bars are $95 \%$ confidence intervals about the mean. 


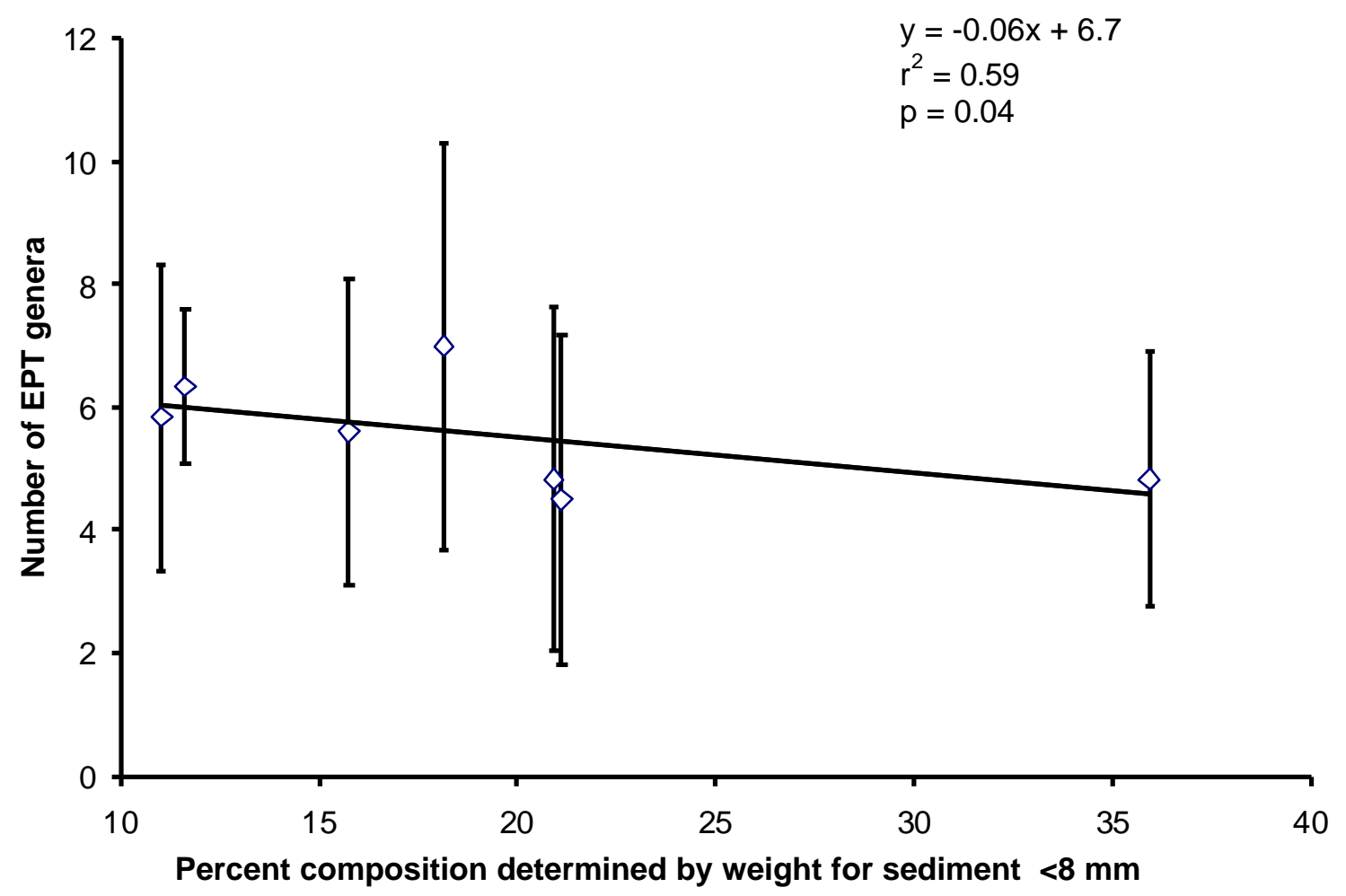

Figure 2. Negative relationships between EPT richness and sediment less than $8 \mathrm{~mm}$ in the fall of 1999. Values are mean number of genera per sample for each stream. Error bars represent $95 \%$ confidence intervals. 

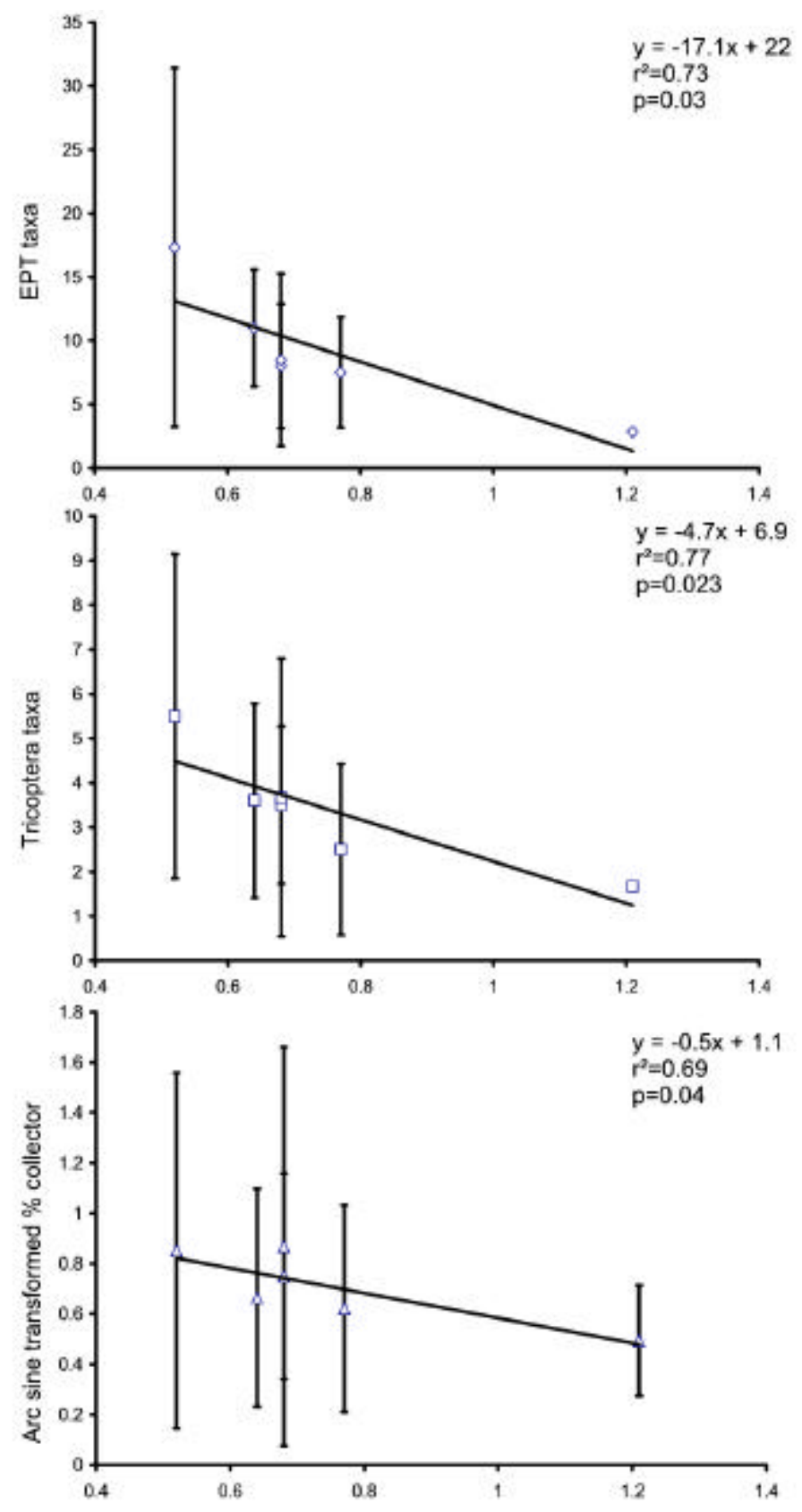

Percent composition of sediment less than $0.125 \mathrm{~mm}$ determined by weight

Figure 3. Negative relationships between EPT taxa richness, Trichoptera taxa richness, $\%$ collector with increasing sediment less than $0.125 \mathrm{~mm}$ in riffles during the fall of 1998. Values are mean number of genera per sample for each stream or an arc sine transformed mean percentage of collectors per sample per stream. Error bars represent $95 \%$ confidence intervals. 

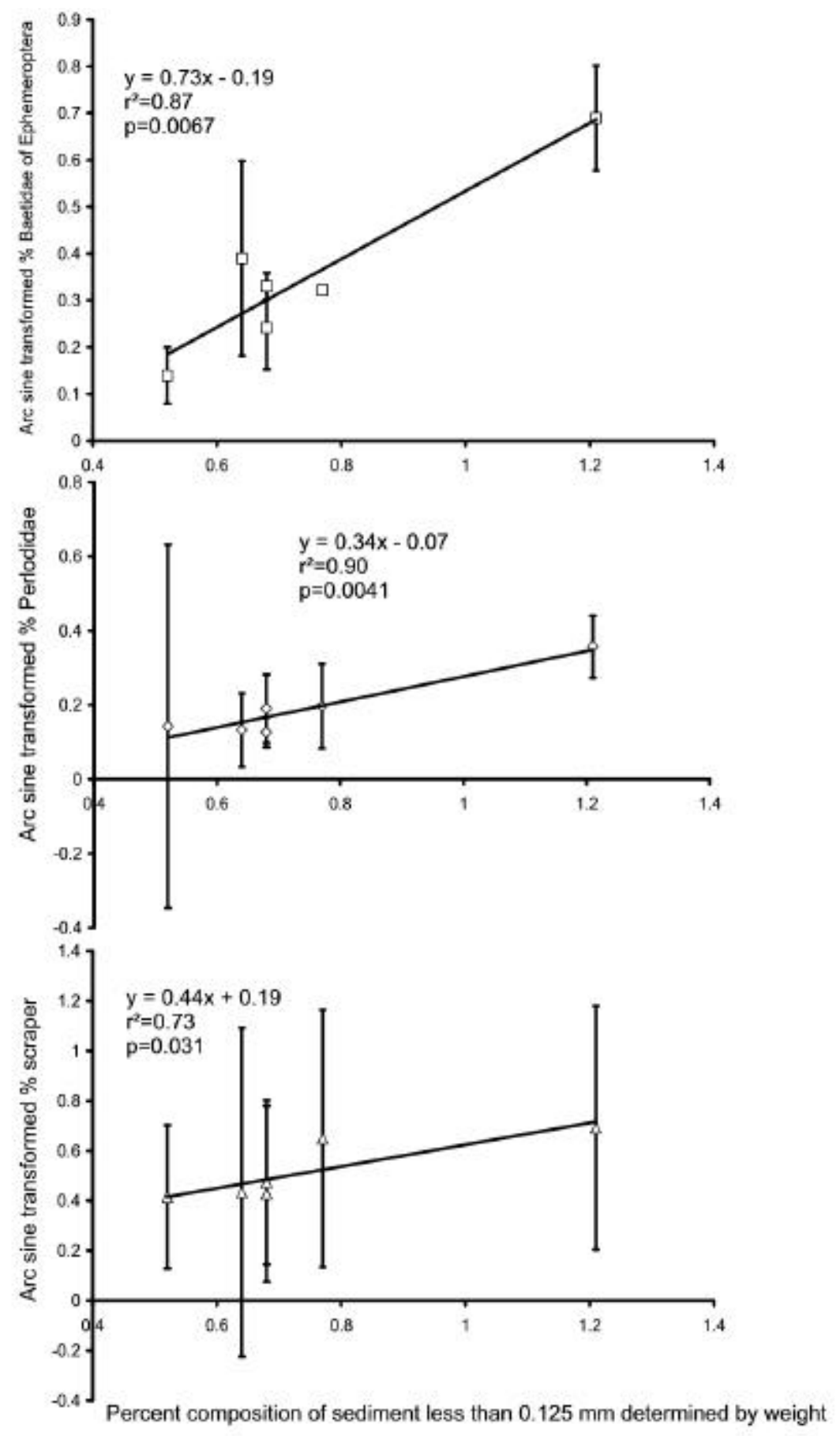

Figure 4. Positive relationships between \% Baetidae of Ephemeroptera, \% Perlodidae, and \% scraper with increasing sediment less than $0.125 \mathrm{~mm}$ in riffles during the fall of 1998. Values are arc sine transformed mean percentages of each group per stream. Error bars are $95 \%$ confidence intervals. 

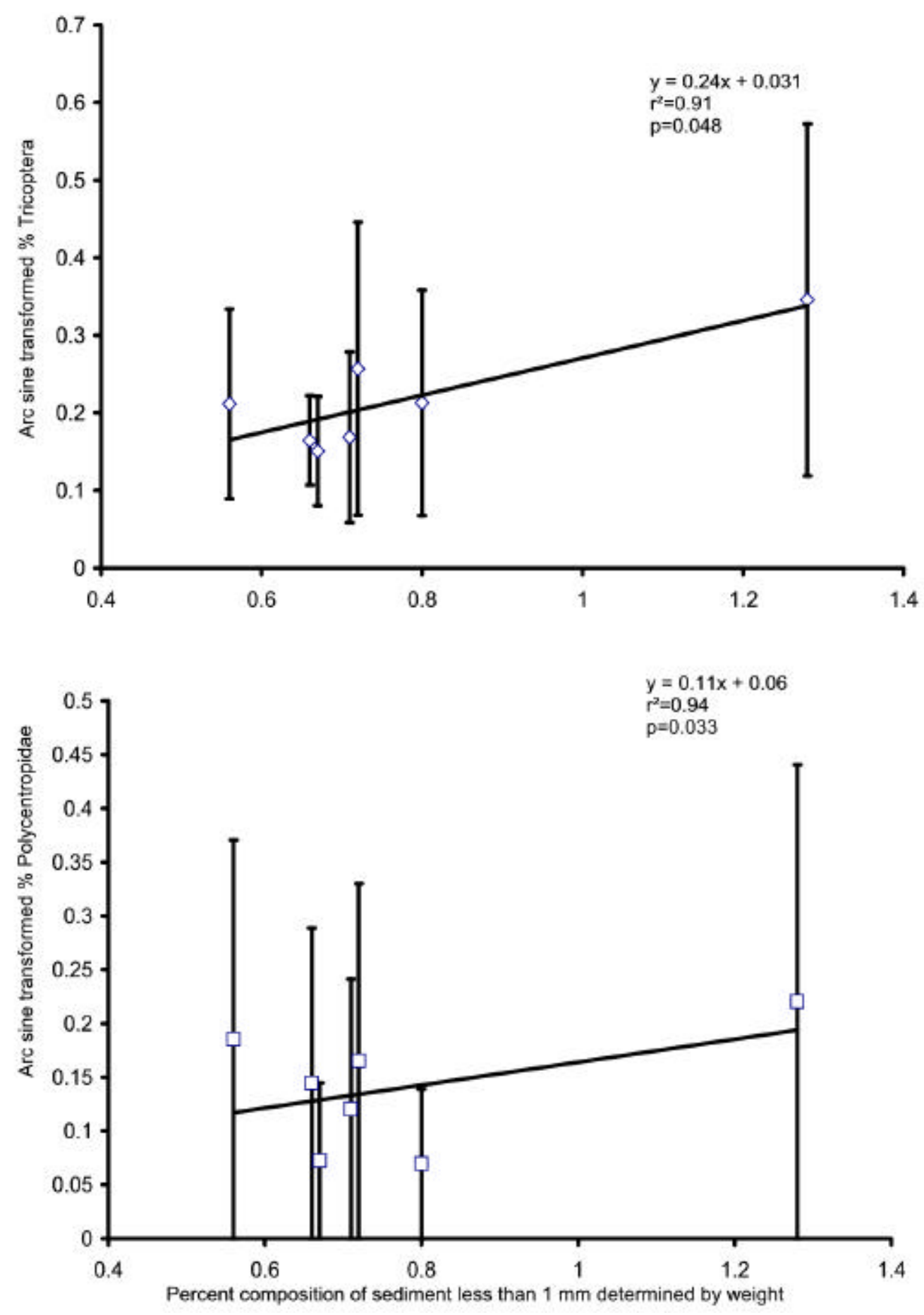

Figure 5. Positive relationships between \% Trichoptera and \% Polycentropidae with increasing sediment less than $1 \mathrm{~mm}$ in riffles during the spring of 1999. Values are arc sine transformations of mean percentages of each group in a sample per stream. Error bars are $95 \%$ confidence intervals. 


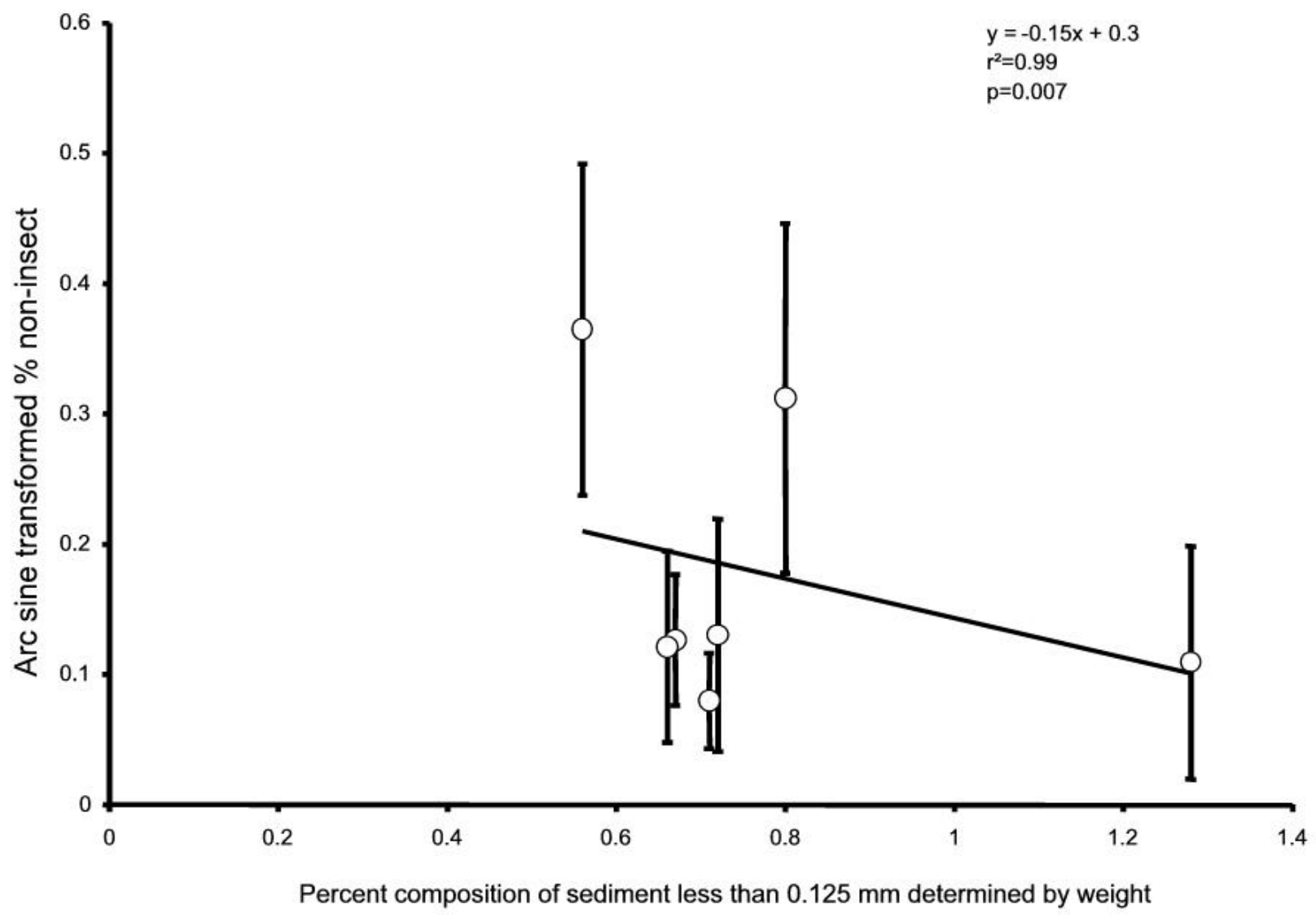

Figure 6 . The metric $\%$ non-insect declines with increasing sediment less than 0.125 $\mathrm{mm}$ in riffles during the spring of 1999 . Values are arc sine transformed mean percentages per stream. Error bars are 95\% confidence intervals. 


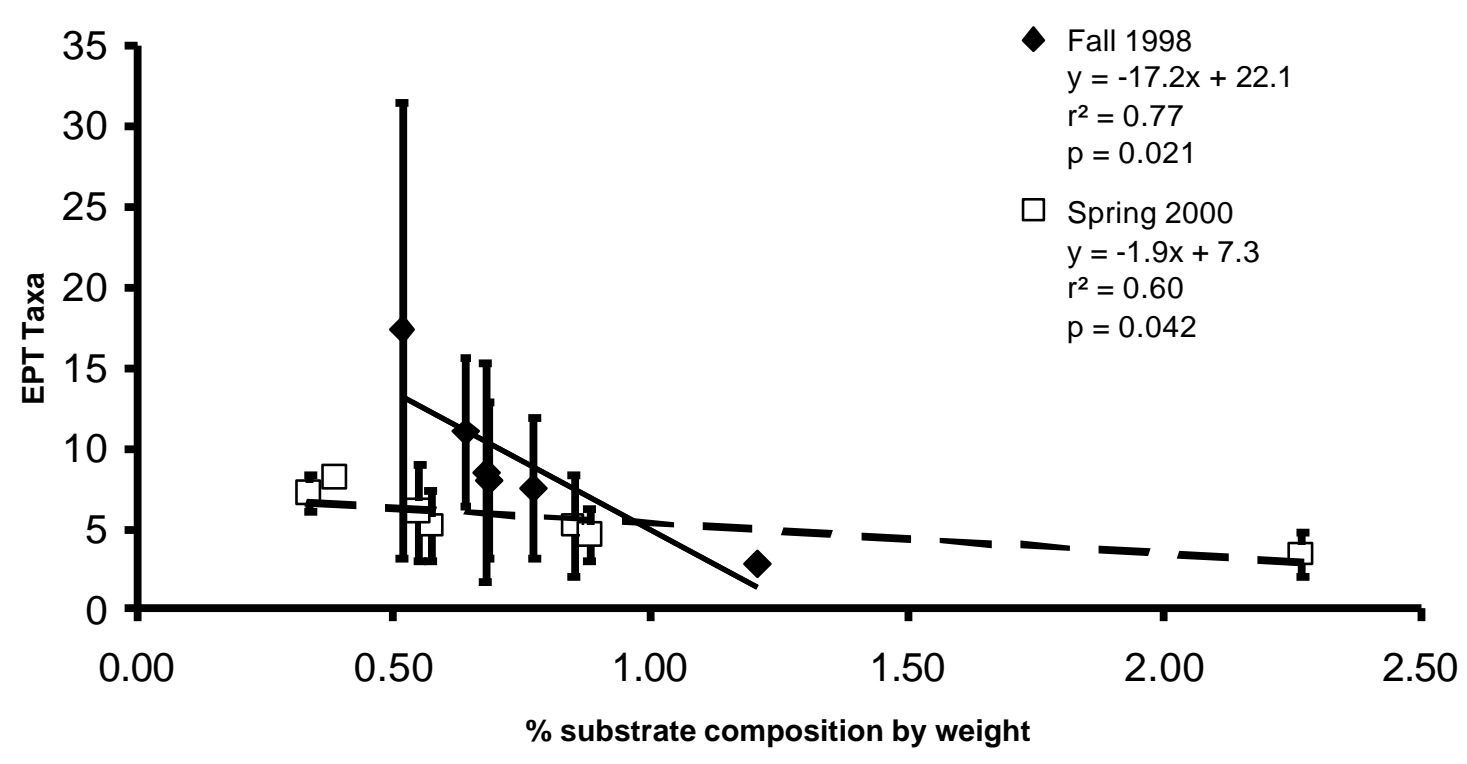

Figure 7. Negative relationships between EPT taxa richness and fine sediment $(<0.125$ $\mathrm{mm}$ in Fall 1998) and (<0.25 mm in Spring 2000). Values are number of genera per sample in each stream. Error bars are 95\% confidence intervals. 
Table 1. Physical habitat and water quality characteristics for 7 streams in the Monongahela National Forest.

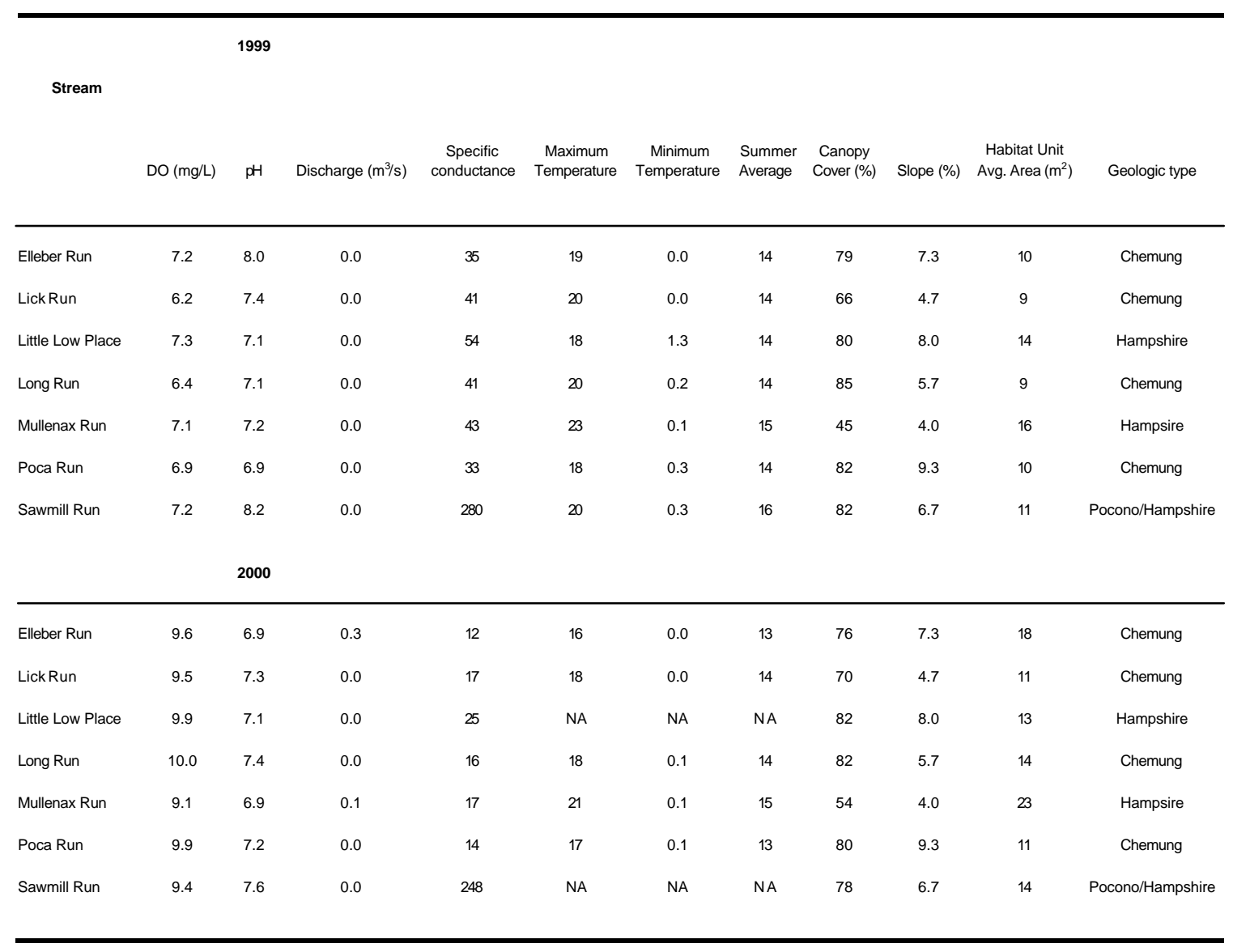


Table 2. Water chemistry characteristics collected during storm events during 2000 in 7 streams in the Monongahela National Forest.

\begin{tabular}{|c|c|c|c|c|c|c|c|c|}
\hline Stream & $\begin{array}{c}\text { Dissolved } \\
\text { organic } \\
\text { carbon } \\
(\mathrm{mg} / \mathrm{L})\end{array}$ & ANC $(\mu \mathrm{eq} / \mathrm{L})$ & $\begin{array}{l}\text { Alkalinity } \\
\text { (mg/L) }\end{array}$ & $\begin{array}{l}\text { Magnesium } \\
(\mathrm{mg} / \mathrm{L})\end{array}$ & $\begin{array}{c}\text { Calcium } \\
(\mathrm{mg} / \mathrm{L})\end{array}$ & Tot. Al (mg/L) & $\begin{array}{c}\text { Organic Al } \\
(\mathrm{mg} / \mathrm{L})\end{array}$ & $\begin{array}{c}\text { Inorg. Al } \\
(\mathrm{mg} / \mathrm{L})\end{array}$ \\
\hline Elleber Run & 0.7 & 72 & 3.7 & 0.7 & 1.8 & 0.02 & 0.02 & 0.00 \\
\hline Lick Run & 1.3 & 92 & 4.7 & 0.9 & 1.9 & 0.05 & 0.06 & 0.00 \\
\hline Little Low Place & 1.2 & 86 & 4.5 & 0.9 & 2.2 & 0.04 & 0.03 & 0.01 \\
\hline Long Run & 0.9 & 68 & 3.6 & 0.9 & 1.9 & 0.03 & 0.01 & 0.02 \\
\hline Mullenax Run & 1.7 & 1488 & 83.7 & 1.8 & 27.0 & 0.08 & 0.05 & 0.03 \\
\hline Poca Run & 0.9 & 65 & 3.4 & 0.8 & 1.7 & 0.02 & 0.02 & 0.00 \\
\hline Sawmill Run & 1.7 & 1439 & 74.1 & 2.2 & 27.0 & 0.04 & 0.02 & 0.02 \\
\hline
\end{tabular}


Table 3. Mean sediment in 7 study streams in the Monongahela National Forest.

\begin{tabular}{|c|c|c|c|c|c|c|c|c|c|c|c|}
\hline \multicolumn{12}{|c|}{$\begin{array}{c}\text { Percent finer than } \\
\text { Fall } 1998\end{array}$} \\
\hline Stream & Fredle index & $32 \mathrm{~mm}$ & $16 \mathrm{~mm}$ & $8 \mathrm{~mm}$ & $4 \mathrm{~mm}$ & $2 \mathrm{~mm}$ & $1 \mathrm{~mm}$ & $0.5 \mathrm{~mm}$ & $0.25 \mathrm{~mm}$ & $0.125 \mathrm{~mm}$ & $0.063 \mathrm{~mm}$ \\
\hline Elleber Run & 0.9 & 20.0 & 19.4 & 11.2 & 6.2 & 4.4 & 3.2 & 1.8 & 0.7 & 0.7 & 0.1 \\
\hline Lick Run & 1.8 & 38.9 & 38.8 & 21.2 & 14.3 & 8.4 & 5.0 & 3.0 & 1.9 & 1.2 & 0.6 \\
\hline Little Low Place & 1.3 & 28.6 & 28.5 & 16.3 & 10.6 & 4.9 & 2.2 & 1.0 & 0.5 & 0.6 & 0.0 \\
\hline Long Run & 1.4 & 34.3 & 34.2 & 21.5 & 15.3 & 8.4 & 3.9 & 1.4 & 0.7 & 0.7 & 0.2 \\
\hline Mullenax Run & 1.1 & 34.1 & 34.0 & 22.3 & 15.3 & 9.5 & 7.0 & 4.8 & 2.1 & 0.5 & 0.1 \\
\hline Poca Run & 1.6 & 25.9 & 25.8 & 14.5 & 9.7 & 5.4 & 3.6 & 2.4 & 1.4 & 0.8 & 0.2 \\
\hline Sawmill Run & NA & NA & NA & NA & NA & NA & NA & NA & NA & NA & NA \\
\hline \multicolumn{12}{|c|}{ Spring 1999} \\
\hline Elleber Run & 1.0 & 20.0 & 19.4 & 11.2 & 6.2 & 4.4 & 3.2 & 1.8 & 0.8 & 0.7 & 0.1 \\
\hline Lick Run & 1.8 & 39.0 & 38.8 & 21.3 & 14.4 & 8.5 & 5.1 & 3.1 & 2.0 & 1.3 & 0.7 \\
\hline Little Low Place & 1.3 & 28.7 & 28.5 & 16.3 & 10.6 & 5.0 & 2.3 & 1.1 & 0.6 & 0.7 & 0.1 \\
\hline Long Run & 1.4 & 34.4 & 34.3 & 21.5 & 15.3 & 8.4 & 4.0 & 1.5 & 0.8 & 0.7 & 0.2 \\
\hline Mullenax Run & 1.1 & 34.2 & 33.0 & 22.3 & 15.4 & 9.5 & 7.1 & 4.8 & 2.1 & 0.6 & 0.1 \\
\hline Poca Run & 1.5 & 25.9 & 25.8 & 14.5 & 9.7 & 5.4 & 3.6 & 2.5 & 1.4 & 0.8 & 0.2 \\
\hline Sawmill Run & 0.8 & 31.1 & 30.9 & 20.2 & 13.4 & 6.8 & 4.2 & 2.6 & 1.2 & 0.7 & 0.2 \\
\hline \multicolumn{12}{|c|}{ Fall 1999} \\
\hline Elleber Run & 1.3 & 42.9 & 41.9 & 27.1 & 16.6 & 8.1 & 4.5 & 3.1 & 1.7 & 4.2 & 0.21 \\
\hline Lick Run & 1.1 & 44.2 & 43.8 & 35.9 & 8.4 & 5.2 & 3.0 & 1.7 & 0.9 & 1.5 & 0.00 \\
\hline Little Low Place & 0.9 & 20.4 & 20.1 & 11.6 & 6.4 & 3.4 & 1.8 & 0.7 & 0.4 & 1.5 & 0.10 \\
\hline Long Run & 1.0 & 31.9 & 31.5 & 20.9 & 13.3 & 7.1 & 3.7 & 1.6 & 0.7 & 1.8 & 0.25 \\
\hline Mullenax Run & 0.5 & 24.8 & 24.4 & 18.1 & 12.2 & 9.0 & 7.3 & 5.1 & 2.4 & 1.7 & 0.26 \\
\hline Poca Run & 1.0 & 18.3 & 17.9 & 11.0 & 6.8 & 3.9 & 2.5 & 1.7 & 1.1 & 1.6 & 0.12 \\
\hline Sawmill Run & 0.8 & 24.1 & 23.6 & 15.8 & 10.3 & 6.4 & 4.0 & 2.6 & 1.2 & 1.9 & 0.26 \\
\hline \multicolumn{12}{|c|}{ Spring 2000} \\
\hline Elleber Run & 1.5 & 31.8 & 31.2 & 11.5 & 7.1 & 3.0 & 1.6 & 1.0 & 0.6 & 2.6 & 0.1 \\
\hline Lick Run & 1.1 & 22.8 & 22.1 & 12.6 & 7.5 & 4.2 & 2.0 & 0.9 & 0.6 & 2.6 & 0.0 \\
\hline Little Low Place & 0.9 & 20.6 & 20.1 & 11.6 & 6.4 & 3.4 & 1.8 & 0.7 & 0.4 & 2.2 & 0.1 \\
\hline Long Run & 1.0 & 33.1 & 32.3 & 20.3 & 12.4 & 6.5 & 3.2 & 1.6 & 0.9 & 3.3 & 0.3 \\
\hline Mullenax Run & 0.9 & 39.4 & 38.7 & 25.3 & 16.9 & 11.4 & 8.4 & 5.5 & 2.3 & 2.8 & 0.2 \\
\hline Poca Run & 1.2 & 15.6 & 15.0 & 7.9 & 3.6 & 1.3 & 0.7 & 0.4 & 0.3 & 2.7 & 0.0 \\
\hline Sawmill Run & 0.9 & 33.4 & 32.6 & 22.2 & 14.6 & 4.6 & 2.9 & 1.9 & 0.9 & 3.1 & 0.2 \\
\hline
\end{tabular}


Table 4. EPT taxa composition in six streams in the Monongahela National Forest in the fall of 1998 from combined pool and riffle samples. Genera are listed where differences in genera were found in the six streams.

\begin{tabular}{|c|c|c|c|c|c|c|c|c|c|}
\hline Order & Family & Genus & $\begin{array}{l}\text { Poca Run } \\
0.34 \%<0.25 \mathrm{~mm}\end{array}$ & $\begin{array}{l}\text { Little Low Place } \\
0.39 \%<0.25 \mathrm{~mm}\end{array}$ & $\begin{array}{c}\text { Elleber Run } \\
0.57 \%<0.25 \mathrm{~mm}\end{array}$ & $\begin{array}{c}\text { Lick Run } \\
0.55 \%<0.25 \mathrm{~mm}\end{array}$ & $\begin{array}{c}\text { Long Run } \\
0.85 \%<0.25 \mathrm{~mm}\end{array}$ & $\begin{array}{c}\text { Sawmill Run } \\
0.88 \%<0.25 \mathrm{~mm}\end{array}$ & $\begin{array}{c}\text { Mullenax Run } \\
2.27 \%<0.25 \mathrm{~mm}\end{array}$ \\
\hline \multicolumn{10}{|c|}{ Ephemeroptera } \\
\hline & \multirow{3}{*}{$\begin{array}{l}\text { Baetidide } \\
\text { Baetiscidae } \\
\text { Ephemeridae } \\
\text { Ephemerellidae }\end{array}$} & & $x$ & $x$ & $x$ & $\mathrm{x}$ & $\mathrm{x}$ & & $x$ \\
\hline & & & & & & $x$ & & x & $x^{2}$ \\
\hline & & $\begin{array}{l}\text { Attenella spp. } \\
\text { Drunella spop. } \\
\text { Ephemerella spp. } \\
\text { Euryophella sppp. } \\
\text { Seratella spp. }\end{array}$ & $\begin{array}{l}x \\
x\end{array}$ & $\begin{array}{l}x \\
x\end{array}$ & $\begin{array}{l}x \\
x\end{array}$ & $\begin{array}{l}x \\
x\end{array}$ & $\begin{array}{l}x \\
x\end{array}$ & $\begin{array}{l}x \\
x\end{array}$ & $\begin{array}{l}x \\
x\end{array}$ \\
\hline & \multirow{2}{*}{ Heptagenidae } & $\begin{array}{l}\text { Epeorus spp. } \\
\text { Leucrocuta spo. }\end{array}$ & $x$ & x & $\begin{array}{l}x \\
x \\
x\end{array}$ & $\begin{array}{l}x \\
x\end{array}$ & $x$ & & $x$ \\
\hline & & $\begin{array}{l}\text { Nixe spp. } \\
\text { Stenororonspo. } \\
\text { Stenonema sop. }\end{array}$ & & $x$ & $\mathrm{x}$ & $x$ & & $\mathrm{x}$ & $x$ \\
\hline & $\begin{array}{l}\text { Isonychidae } \\
\text { Leptophlebidae }\end{array}$ & & $x$ & $x$ & $x$ & & $x$ & $x$ & $x$ \\
\hline \multirow{5}{*}{ Plecoptera } & $\begin{array}{l}\text { Poimytarcicaee } \\
\text { Siphlonuridae }\end{array}$ & & $\mathrm{x}$ & & & $\begin{array}{l}x \\
x \\
x\end{array}$ & & & $x$ \\
\hline & Capniidae & & & & & $x$ & & & \\
\hline & $\begin{array}{l}\text { Chloropereridae } \\
\text { Leucrtidae }\end{array}$ & & $\begin{array}{l}x \\
x \\
x\end{array}$ & $\begin{array}{l}x \\
x\end{array}$ & $\begin{array}{l}x \\
x\end{array}$ & $\begin{array}{l}x \\
x\end{array}$ & $\begin{array}{l}x \\
x\end{array}$ & $\begin{array}{l}x \\
x\end{array}$ & $\begin{array}{l}x \\
x\end{array}$ \\
\hline & $\begin{array}{l}\text { Nemouridae } \\
\text { Peltoperidae }\end{array}$ & & $\begin{array}{l}x \\
x \\
x\end{array}$ & $\begin{array}{l}x \\
x \\
x\end{array}$ & 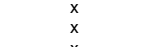 & $\begin{array}{l}x \\
x\end{array}$ & $x$ & $\begin{array}{l}x \\
x\end{array}$ & $x$ \\
\hline & $\begin{array}{l}\text { Perildae } \\
\text { Perfodidae }\end{array}$ & & $\begin{array}{l}x \\
x \\
x\end{array}$ & $\mathrm{x}$ & $\begin{array}{l}x \\
x \\
x\end{array}$ & $\begin{array}{l}x \\
x \\
x\end{array}$ & $\begin{array}{l}x \\
x \\
x \\
x\end{array}$ & $\begin{array}{l}x \\
x \\
x\end{array}$ & $x$ \\
\hline \multirow{7}{*}{ Tricoptera } & Glossosomatidae & & & $x$ & & & $\mathrm{x}$ & $x$ & \\
\hline & $\begin{array}{l}\text { Helicopsychidae } \\
\text { Hydropsychidaae }\end{array}$ & & & & & & & & \\
\hline & & \multirow{4}{*}{$\begin{array}{l}\text { Cheumatopsyche spp. } \\
\text { Hydropsyche spop. } \\
\text { Macrostenum spp. }\end{array}$} & x & $\mathrm{x}$ & $x$ & $\begin{array}{l}x \\
x\end{array}$ & $\begin{array}{l}x \\
x\end{array}$ & $x$ & $x$ \\
\hline & Limnephilidae & & x & $\mathrm{x}$ & $\mathrm{x}$ & & & & 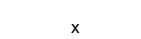 \\
\hline & $\begin{array}{l}\text { Philipotamamidae } \\
\text { Polycentropidae }\end{array}$ & & $\begin{array}{l}x \\
x\end{array}$ & & $\begin{array}{l}x \\
x\end{array}$ & $\begin{array}{l}x \\
x\end{array}$ & $\begin{array}{l}x \\
x\end{array}$ & $\begin{array}{l}x \\
x\end{array}$ & $\begin{array}{l}x \\
x\end{array}$ \\
\hline & $\begin{array}{l}\text { Rhyacopphilidae } \\
\text { hlononida }\end{array}$ & & $x$ & & $x$ & $\mathrm{x}$ & $\mathrm{x}$ & $\mathrm{x}$ & \\
\hline & $\begin{array}{l}\text { er of EPidae } \\
\text { er genera per }\end{array}$ & er sample & 14 & 13 & $\begin{array}{l}x \\
13 \\
\end{array}$ & 14 & 15 & 12 & 10 \\
\hline
\end{tabular}


Table 5. Metric responses to fine sediment in 7 streams in the Monongahela National Forest during the fall of 1999.

Metric

Sediment sizes

Response

$r^{2} \quad p$-value

\begin{tabular}{lllll}
\hline Macroinvertebrate density & finer than $4 \mathrm{~mm}$ & - & 0.61 & 0.04 \\
EPT taxa richness & finer than $8 \mathrm{~mm}$ & - & 0.59 & 0.04 \\
Plecoptera taxa richness & finer than $8 \mathrm{~mm}$ & - & 0.69 & 0.02 \\
Diptera taxa richness & finer than $0.125 \mathrm{~mm}$ & - & 0.74 & 0.01 \\
Odonata taxa richness & finer than $0.063 \mathrm{~mm}$ & - & 0.85 & 0.00 \\
\% Tricoptera & finer than $0.125 \mathrm{~mm}$ & + & 0.75 & 0.01 \\
\% non-insect & finer than $4 \mathrm{~mm}$ & - & 0.73 & 0.01 \\
\% Ephemeridae & finer than $2 \mathrm{~mm}$ & + & 0.81 & 0.04 \\
\% Leucrocuta spp. & finer than $0.250 \mathrm{~mm}$ & - & 0.80 & 0.04 \\
\% Perlodidae & finer than $0.250 \mathrm{~mm}$ & + & 0.58 & 0.05 \\
\% Limnephilidae & finer than $4 \mathrm{~mm}$ & + & 0.73 & 0.03 \\
\% Philopotamidae & finer than $0.125 \mathrm{~mm}$ & + & 0.78 & 0.05 \\
\% Polycentropidae & finer than $0.125 \mathrm{~mm}$ & + & 0.74 & 0.01 \\
\hline & & & & \\
\hline
\end{tabular}


Table 6. EPT taxa composition in seven streams in the Monongahela National Forest in the summer of 2000 from combined pool and riffle samples. Genera are listed where differences in genera were found in the six streams.

\begin{tabular}{|c|c|c|c|c|c|c|c|c|}
\hline & & & Mullenax Run & Little Low Place & Long Run & Elleber Run & Poca Run & Lick Run \\
\hline Order & Family & Genus & $0.52 \%<0.125 \mathrm{~mm}$ & $0.64 \%<0.0125 \mathrm{~mm}$ & $0.68 \%<0.125 \mathrm{~mm}$ & $0.68 \%<0.125 \mathrm{~mm}$ & $0.77 \%<0.125 \mathrm{~mm}$ & $1.21 \%<0.125 \mathrm{~mm}$ \\
\hline \multirow[t]{14}{*}{ Ephemeroptera } & Ameletidae & & $\mathrm{x}$ & $x$ & $x$ & & & \\
\hline & Baetidae & & $x$ & $x$ & $x$ & $x$ & $x$ & $x$ \\
\hline & Baetiscidae & & $\mathrm{x}$ & $x$ & & & & \\
\hline & Ephemeridae & & & & & & & \\
\hline & Ephemerellidae & $\begin{array}{l}\text { Attenella spp. } \\
\text { Drunella spp. }\end{array}$ & $\begin{array}{l}x \\
x\end{array}$ & $\begin{array}{l}x \\
x\end{array}$ & $\mathrm{x}$ & & $x$ & $x$ \\
\hline & & $\begin{array}{l}\text { Ephemerella spp. } \\
\text { Euryophella spp. }\end{array}$ & $x$ & $\mathrm{x}$ & $\begin{array}{l}x \\
x\end{array}$ & $\mathrm{x}$ & $\mathrm{x}$ & $\mathrm{x}$ \\
\hline & & Seratella spp. & $\mathrm{x}$ & $\mathrm{x}$ & & & & \\
\hline & Heptagenidae & $\begin{array}{l}\text { Epeorus spp. } \\
\text { Leucrocuta spp. }\end{array}$ & $\mathrm{x}$ & $\begin{array}{l}x \\
x\end{array}$ & $\mathrm{x}$ & $\begin{array}{l}x \\
x\end{array}$ & $\mathrm{x}$ & \\
\hline & & $\begin{array}{l}\text { Nixe spp. } \\
\text { Sip. }\end{array}$ & $x$ & $\hat{x}$ & & & & \\
\hline & & $\begin{array}{l}\text { Stenocron spp. } \\
\text { Stenonema spp. }\end{array}$ & $\begin{array}{l}x \\
x\end{array}$ & $\begin{array}{l}x \\
x\end{array}$ & $x$ & $\mathrm{x}$ & $x$ & \\
\hline & Isonychidae & & $\mathrm{x}$ & & & & & $\mathrm{x}$ \\
\hline & Leptophlebidae & & $x$ & $x$ & $x$ & $x$ & $x$ & \\
\hline & Polymitarcidae & & & & & & & $x$ \\
\hline & Siphlonuridae & & & & $\mathrm{x}$ & & & \\
\hline \multirow[t]{9}{*}{ Plecoptera } & Chloroperlidae & & $x$ & $x$ & $x$ & $x$ & $x$ & $x$ \\
\hline & Leuctridae & & $x$ & $x$ & $x$ & $x$ & $x$ & $x$ \\
\hline & Nemouridae & & $\mathrm{x}$ & & & & $x$ & \\
\hline & Peltoperlidae & & $x$ & $x$ & & & $x$ & \\
\hline & Perlidae & $\begin{array}{l}\text { Acroneuria spp. } \\
\text { Hansonoperla spp. }\end{array}$ & $\begin{array}{l}x \\
x\end{array}$ & $x$ & & $x$ & & $x$ \\
\hline & & Perlesta spp. & $\mathrm{x}$ & $\mathrm{x}$ & & & & \\
\hline & Perlodidae & $\begin{array}{l}\text { Diura spp. } \\
\text { Isoperla spp. }\end{array}$ & & & & & & $\begin{array}{l}x \\
x\end{array}$ \\
\hline & & Yugus spp. & $x$ & $x$ & $x$ & $\mathrm{x}$ & $x$ & \\
\hline & Pteronarcyidae & & & $x$ & $x$ & & $x$ & \\
\hline \multirow[t]{10}{*}{ Tricoptera } & Glossosomatidae & & $x$ & $\mathrm{x}$ & & $x$ & & $x$ \\
\hline & Helicopsychidae & & & & & $x$ & & \\
\hline & Hydropsychidae & $\begin{array}{l}\text { Cheumatopsyche spp. } \\
\text { Hydropsyche spp. } \\
\text { Macrostenum spp. }\end{array}$ & $\begin{array}{l}x \\
x\end{array}$ & $x$ & $\mathrm{x}$ & $\mathrm{x}$ & $\mathrm{x}$ & $\mathrm{x}$ \\
\hline & Limnephilidae & & & $x$ & $x$ & & $x$ & \\
\hline & Philopotamidae & $\begin{array}{l}\text { Chimarra spp. } \\
\text { Dolophilodes spo. }\end{array}$ & $x$ & $x$ & $x$ & $\mathrm{x}$ & & $x$ \\
\hline & & Wormaldia spp. & $\hat{x}$ & $\mathrm{x}$ & $x$ & & & \\
\hline & Polycentropidae & & $x$ & & $x$ & $x$ & & \\
\hline & Psychomyiidae & & $x$ & $x$ & $x$ & & & \\
\hline & Rhyacophilidae & & & $x$ & & $x$ & $\mathrm{x}$ & \\
\hline & Ueonidae & & $x$ & $x$ & $\mathrm{x}$ & $x$ & $x$ & \\
\hline \multicolumn{3}{|c|}{ Average number of EPT genera per sample } & 54 & 28 & 43 & 32 & 34 & 15 \\
\hline
\end{tabular}


Table 7. Summary of metric responses to fine sediment size classes (\%less than size listed) with and without pool habitat included in analyses. A (+) or (-) next to the sediment size class indicates the direction of the response. Sediment size classes are in $\mathrm{mm}$.

\begin{tabular}{|c|c|c|c|c|c|c|c|c|}
\hline \multirow[t]{2}{*}{ Metric } & \multicolumn{2}{|c|}{ Fall 1998} & \multicolumn{2}{|c|}{ Spring 1999} & \multicolumn{2}{|c|}{ Fall 1999} & \multicolumn{2}{|c|}{ Spring 2000} \\
\hline & With pools & No pools & With pools & No pools & With pools & No pools & With pools & Nopools \\
\hline Density & & & & & (-) 4 & & & \\
\hline Ephemeroptera taxa richness & & & & & & & (-) 0.125 & (-) 0.125 \\
\hline EPT taxa richness & (-) 0.125 & $(-) 0.125$ & & & (-) 8 & & (-) 0.25 & (-) 0.25 \\
\hline Odonata taxa richness & & & & & (+) 0.0063 & & & \\
\hline Plecoptera taxa richness & (-) 0.125 & & & & (-) 8 & (+) 0.125 & & \\
\hline Tricoptera taxa richness & (-) 0.125 & $(-) 0.125$ & & & & $(+) 0.125$ & & \\
\hline$\%$ Ameletidae & & (+) 0.125 & & & & & & \\
\hline \% Baetidae of Ephemeroptera & & (+) 0.125 & & & & & & $(+) 8$ \\
\hline$\%$ Chironomidae of Diptera & & $(-) 1$ & & & & & & \\
\hline$\%$ Chloroperidae & & & & $(-) 1$ & & & & \\
\hline$\%$ Clinger & & & & $(-) 2$ & & & & \\
\hline$\%$ Collector & & (-) 0.125 & & & & & & \\
\hline$\%$ Ephemeridae & & (+) 0.25 & & & (+) 2 & & & \\
\hline$\%$ Heptagenidae & & & & & & & & (-) 8 \\
\hline$\%$ Hydropsychidae & & (+) 0.25 & & & & & & \\
\hline$\%$ Hydropsychidae of Tricoptera & & & & & & (+) 1 & & (-) 0.063 \\
\hline \% Leucritidae & & (+) 0.063 & & & & & & \\
\hline$\%$ Leucrocuta & & & & & (-) 0.25 & & & \\
\hline$\%$ Limnephilidae & & & & & $(+) 4$ & & & \\
\hline$\%$ Non- insect & $(+) 2$ & & & (-) 0.125 & (-) 4 & & & \\
\hline$\%$ Odonata & & & (+) 0.063 & & & & & \\
\hline \% Oligochaete & (+) 0.125 & & $(+) 2$ & & & & & \\
\hline$\%$ Perlodidae & & (+) 0.125 & & & (+) 0.125 & & & \\
\hline$\%$ Philopotamidae & & & & & (+) 0.25 & & & \\
\hline$\%$ Polycentropidae & & & & $(+) 1$ & & & & \\
\hline$\%$ Scraper & & (+) 0.125 & & & & & & \\
\hline \% Swimmer & & & & & (+) 0.125 & (+) 0.125 & & $(+) 4$ \\
\hline \%Tricoptera & & & & (+) 1 & & & & \\
\hline
\end{tabular}


Table 8. Summaries of metric responses to sediment in Appalachian studies.

\begin{tabular}{|c|c|c|}
\hline Metric & Response & Source \\
\hline$\%$ Ameletidae & $(+)$ & Chapter 3 \\
\hline$\%$ Baetidae of Ephemeroptera & $(+)$ & Angradi 1999; Chapter 3 \\
\hline$\%$ Chironomidae of Chironomidae & $(-)$ & Angradi 1999 \\
\hline$\%$ Chironomidae of Diptera & $(-)$ & Chapter 3 \\
\hline$\%$ Chloroperlidae & $(-)$ & Chapter 3 \\
\hline$\%$ Climber & $(+)$ & Summer 1999 experiment \\
\hline$\%$ Clinger & $(-)$ & Chapter 3 \\
\hline$\%$ Ephemeridae & $(+)$ & Chapter 3 \\
\hline$\%$ Heptageniidae & $(-)$ & Chapter 3 \\
\hline$\%$ Hydropsychidae & $(+)$ & Chapter 3 \\
\hline$\%$ Hydropsychidae of Trichoptera & $(-)$ and $(+)$ & Chapter 3 \\
\hline$\%$ Leucrtidae & $(+)$ & Chapter 3 \\
\hline$\%$ Leucrocuta & $(-)$ & Chapter 3 \\
\hline \% Limnephilidae & $(+)$ & Chapter 3 \\
\hline$\%$ Non-insect & $(+)$ & Chapter 3 \\
\hline$\%$ Odonata & $(+)$ & Chapter 3 \\
\hline$\%$ Oligochaeta & $(+)$ & Chapter 3 \\
\hline$\%$ Orthocladiinae of Chironomidae & $(+)$ & Angradi 1999 \\
\hline$\%$ Perlodidae & $(+)$ & Chapter 3 \\
\hline$\%$ Philopotamidae & $(+)$ & Chapter 3 \\
\hline$\%$ Polycentropodidae & $(+)$ & Chapter 3 \\
\hline$\%$ Scraper & $(-)$ & Chapter 3 \\
\hline$\%$ Swimmer & $(+)$ & Chapter 3 \\
\hline$\%$ Tricoptera & $(+)$ & Chapter 3 \\
\hline EPT taxa richness & $(-)$ & Angradi 1999; Chapter 3; Summer 1999 experiment \\
\hline Ephemeroptera taxa richness & $(-)$ & Chapter 3 \\
\hline Odonata taxa richness & $(+)$ & Chapter 3 \\
\hline Plecoptera taxa richness & $(-)$ and $(+)$ & Chapter 3 \\
\hline Trichoptera taxa richness & $(-)$ and $(+)$ & Chapter 3 \\
\hline Macroinvertebrate biomass & $(-)$ & Angradi 1999 \\
\hline Macroinvertebrate density & $(-)$ & Angradi 1999; Chapter 3 \\
\hline Non-insect taxa richness & $(-)$ & Summer 1999 experiment \\
\hline
\end{tabular}

$(+)$ or (-) indicates direction of response. 


\section{Discussion}

\section{Sediment thresholds}

The goal of this project was to determine a threshold level of fine sediment in the substrate that could be tolerated in aquatic habitats, particularly streams, in a multipleuse forest. I suspected aquatic habitats within the Monongahela National Forest may be compromised by excess fine sediment entering streams (Angradi and Vinson 1996). Rigorous enforcement of BMPs within the Monongahela National Forest has significantly reduced fine sediment inputs from silviculture (Kochenderfer et al. 1997). Furthermore, silviculture within the Monongahela National Forest occurs at a much reduced scale and intensity than in the past (Thomas Cain, USDA Forest Service, pers. comm.). However, an extensive road network from past silvicultural operations and remnants of past land uses input fine sediment into streams (Furniss et al. 1991; Harding et al. 1998). Research conducted in the Monongahela National Forest has demonstrated sensitivity of some macroinvertebrate groups to increasing levels of fine sediment $(\%<2 \mathrm{~mm})$ (Angradi 1999). Therefore, a two-part study was designed to further experimentally test the sensitivity of macroinvertebrate metrics to increasing fine sediment $(\%<2 \mathrm{~mm})$ and to determine the threshold amount of fine sediment that significantly changed either macroinvertebrate abundance or community composition.

The literature concerning the relationships between fine sediment and benthic macroinvertebrates, although plentiful, is somewhat vague and, at times, contradictory in nature. The definition of fine sediment, collection, and measurement techniques have varied widely. Therefore, it has been difficult to build upon previous studies and develop a consensus concerning the relationship between fine sediment and benthic 
macroinvertebrates. Unfortunately, many of the results of past experiments in perturbation and response lack the replication by other researchers necessary to construct a concise and predictive understanding of fine sediment and benthic macroinvertebrate relationships to disturbance (Karr and Chu 1999; Lake 2000). Often, it was not the intent of researchers to fail to corroborate other studies, but instead, many projects were victims of circumstances beyond the control of the researchers. This study is fairly unique, however, because it was designed to replicate and expand upon a previous experiment in fine sediment research. This type of replication of previous experiments in other locations and situations must continue to test the perturbation response patterns of benthic macroinvertebrates to further expand the knowledge base critical to biomonitoring programs (Karr and Chu1999). Therefore, one of the primary outcomes envisioned for this project was to test relationships between benthic macroinvertebrates metrics and fine sediment for sensitivity and reliability.

Most sediment assessment is based upon a system proposed by Cummins (1962) modifying size ranges originally outlined by Wentworth. Studies using this system typically denote sediment less than $2 \mathrm{~mm}$ to be fine sediment (Angradi 1999). Although this system is generally accepted in fisheries-related sediment assessment, the methodology used to describe substrate composition with the Cummins scale has varied. Some authors have used a visual assessment scheme, pebble counts, core samplers, or shovel samples (Grost et al. 1991; McMahon et al. 1996). Each of these methods is fraught with inherent levels of bias and inaccuracy. To further complicate matters, sieving sediment samples in the lab has been performed using different methodologies in different studies (McMahon et al. 1996). However, despite collection 
and assessment vagaries, substrate composition generally has been reported as the amount of a particular size given as a percent of the total composition $(\% \times \mathrm{mm})$ (McMahon et al. 1996). An alternative method of reporting substrate composition used in this study is to report the percent less than a given size (Waters 1995; Angradi 1999). This method is useful as it lumps often very small components of the substrate into larger, more manageable numbers rather than very small percentages. With intrinsic differences in collection technique, most vagaries in fine sediment-macroinvertebrate relationships between studies were probably more an artifact of sampling differences rather than actual differences in fine sediment-macroinvertebrate relationships between studies.

In headwater streams, unlike other bodies of water, the literature is fairly consistent in describing the effects of increasing fine sediment, regardless of assessment and reporting technique, on benthic macroinvertebrates (Brunke and Gosner 1999). One of the earliest papers outlining the deleterious effects of fine sediment upon benthic macroinvertebrates concerned excess fine sediment from silvicultural operations that lowered macroinvertebrate abundance in streams (Tebo 1955). Communities that attempted to exploit the increased fine sediment in the substrate were found to be vulnerable to losses during subsequent flooding (Tebo 1955). Subsequent research corroborated and expanded upon these findings. Rosenberg and Wiens (1978) found experimental additions of sand into streams precipitated the avoidance of substrate by Ephemeropterans, Plecopterans, and Dipterans. As the introduced sand penetrated the substrate, tolerant macroinvertebrates, such as Oligochaetes, were also reduced (Rosenberg and Wiens 
1978). Lamberti and Berg (1995) and Vouri and Joensuu (1996) documented losses of shredders from streams experiencing inputs of fine sediment. In North Carolina, Waters (1995) reported Lenat and associates documented taxonomic shifts from an Ephemeroptera, Plecoptera, and Tricoptera dominated community to a community dominated by other, sediment-tolerant, taxa. Angradi (1999) also observed a reduction in EPT taxa in response to increasing fine sediment. In a review of literature concerning fine sediment, Waters (1995) suggested the reduction in EPT taxa is the principal effect of excess fine sediment in headwater streams. Therefore, it was expected the single stream field experiment component of the study would demonstrate sensitivity of EPT taxa metrics to increasing fine sediment, and the stream surveys would indicate at what amount of specific sizes of fine sediment would a decline in EPT taxa occur.

Furthermore, other relationships between macroinvertebrates and fine sediment (e.g. reductions in macroinvertebrate density or sensitivity of specific taxa within EPT) would also be detectable in the field experiments and stream surveys.

Indeed, the field experiment in Mullenax Run during the early summer of 1999 did appear to corroborate the sensitivity of EPT taxa richness to increasing fine sediment less than $2 \mathrm{~mm}$. As well, stream surveys in the fall of 1998 and spring of 2000 also demonstrated a negative relationship between EPT taxa richness and fine sediment $(<0.25 \mathrm{~mm})$ when in excess of $0.9 \%$ of the substrate. In the stream surveys, macroinvertebrate communities experienced a significant loss of EPT taxa with increasing sediment less than $0.125 \mathrm{~mm}$ in fall 1998 and with increasing sediment less than $0.25 \mathrm{~mm}$ in the summer of 2000 . The stream surveys suggest if fine sediment in the range of $0.25-0.125 \mathrm{~mm}$ or less surpasses approximately $0.9 \%$ of the substrate 
composition that macroinvertebrate community diversity, specifically EPT taxa, will be reduced. In the fall of 1998, the difference in EPT taxa richness between streams that exceeded approximately $0.9 \%$ sediment less than $0.125 \mathrm{~mm}$ in the substrate and the stream that did not, was a significant decline from a mean of 32 EPT genera for the five streams with less than $0.9 \%$ sediment less than $0.125 \mathrm{~mm}$ to only 15 EPT genera in the stream with greater than $0.9 \%$ in the substrate. A similar decline in EPT genera also occurred in the summer of 2000. EPT genera decreased from 13 EPT genera per stream in the six streams less than $0.9 \%$ sediment less than $0.25 \mathrm{~mm}$ to 10 EPT genera in the stream with greater than $0.9 \%$ sediment less than $0.25 \mathrm{~mm}$. Seasonal differences in macroinvertebrate community composition or increased difficulty in identification of smaller $(<1 \mathrm{~mm})$ macroinvertebrates to lower taxonomic units probably accounted for the lower overall EPT diversity in the summer of 2000 (Thorp and Covich 1991; Merritt et al. 1996). Yet, a decline in EPT taxa diversity occurred even in a season with lower overall diversity increasing evidence of the importance of a sediment threshold around $0.9 \%$ of fine sediment. Furthermore, the decline in EPT taxa occurred in two different streams where, regardless of season, fine sediment in excess of $0.9 \%$ triggered the decline in EPT taxa richness. This somewhat refutes any contention that the decline in EPT taxa was due to some unique factor in the stream as two different streams (Mullenax Run and Lick Run) demonstrated a similar threshold of fine sediment at different times. The mean number of EPT taxa in a stream also was significantly different between streams below, and above the $0.9 \%$ fine sediment threshold regardless of which stream fine sediment exceeded the threshold. Other metrics appeared to be related to fine sediment, but were inconsistent in their relationships. 
However, the relationship between EPT taxa richness and increasing fine sediment was not replicated in the 2000 field experiment, and the negative relationship with fine sediment was not detected in stream surveys of spring and fall 1999 due to another perturbation occurring the streams that will be discussed later in this chapter.

This study was not designed to explain the mechanisms through which fine sediment influences macroinvertebrate density and community structure. However, in identifying particular size classes and amounts of fine sediment that influenced macroinvertebrate density and community structure, this study hinted at some of the processes affecting macroinvertebrates as a result of excessive fine sediment. Three hypotheses appeared to be supported by the size classes implicated in this research. One hypothesis proposed by Vouri and Joensuu (1996) was abrasion by fines may have influenced community structure by forcing sensitive macroinvertebrates to relocate. Certainly, Ephemeropterans, some of whom have adaptations of operculate (overlapping) gills for this reason, with fully exposed external gills could suffer clogging or actual destruction of gill tissue from fine sediment particles (Edmunds and Waltz 1996). A second hypothesis is fines less than $0.25 \mathrm{~mm}$ and less than $0.125 \mathrm{~mm}$ fill interstitial spaces at a greater rate than larger substrate particles. Beschta and Jackson (1976) reported the finest particles $(0.2 \mathrm{~mm})$ filled up experimental gravels from the bottom up. Larger particles ( $0.5 \mathrm{~mm}$ or bigger) only penetrated the uppermost levels of the gravel bed (Beschta and Jackson 1976). The third hypothesis is the coating of substrate and subsequent loss in periphyton food sources also was observed by Vouri and Joensuu (1996). Periphyton was never prevalent in the study streams, therefore, it is unlikely the effect of fine sediment was a loss of periphyton grazing areas. Small 
sediment particles, 0.25 and $0.125 \mathrm{~mm}$ and less, are easily transported in streams lending support to abrasion or filling of interstitial spaces as the likely causes of macroinvertebrate declines (Luepold et al. 1964). The mechanism by which these fine particles influence macroinvertebrate communities may be any of these possibilities or other, as yet, unknown mechanisms.

Despite the complications in interpreting the influence of fine sediment upon macroinvertebrates, the macroinvertebrate-fine sediment relationships detected in this study have negative implications to organisms dependent upon macroinvertebrates as food sources. Changes in community composition interrupt normal trophic processing in allocthanous streams as the macroinvertebrate community shifts from scrapers, shredders, and collectors to more omnivores, detritivores, and less effective shredders. Serious consequences to downstream areas may result, as downstream taxa are not as suited to begin trophic processing and rely on headwater taxa to begin leaf litter breakdown (Vannote et al. 1980). Most headwater taxa are unable to relocate downstream due to their inability to adapt to higher flows, different substrates, different temperatures, and different water chemistry found downstream (Thorp and Covich 1991). Excess fine sedimentation leads to a breakdown in the transportation of energy to organisms higher in the trophic cascade. Two scenarios are likely to occur when sedimentation changes the composition of a macroinvertebrate community. In headwater streams, scrapers (usually Ephemeropterans, particularly Heptageniidae) were reduced in both streams (Lick Run in 1998 and Mullenax Run in 2000) with the highest levels of fine sediment. Without scrapers exploiting periphyton and algae, energy from these primary producers in unavailable to predaceous macroinvertebrates 
and fish lowering the overall biomass of predator levels (Waters 1995). The second scenario involved reductions in EPT genera that also reduces the number of shredders present in the streams with the highest levels of fine sediment. This also was noted by Lamberti and Berg (1995) and Vouri and Joensuu (1996) in streams with high levels of fine sediment. If shredder populations are reduced in headwater habitats, macroinvertebrate populations downstream adapted to exploiting processed FPOM will be reduced as FPOM will not be readily available from upstream processing. If this shifting continues too far downstream, water chemistry, temperature, flow velocity, or depth may become unsuitable for shredders limiting processing of CPOM to FPOM (Thorp and Covich 1991). Once again, if this trophic pathway is lost, energy available to support macroinvertebrate and fish predators will be reduced (Waters 1995). Loss of macroinvertebrate taxa due to crossing a sedimentation threshold effectively removes them from trophic processing with serious downstream ramifications.

Although relationships were detected between macroinvertebrates and fine sediment in all seasons, some relationships demonstrated inconsistent response over the course of the study. The inconsistencies in macroinvertebrate-fine sediment relationships during the study period was most likely due to a drought that occurred in the summer of 1999. Precipitation in 1999 was well below the 30-year average for the region (NOAA/NCDC 1999, 2000). The effects of the drought upon each aspect of the study have been covered in Chapters 2 and 3 . In the context of the entire project, the drought hampered replication of the field experiment and an assessment of seasonal influences upon the stream survey. The water years 1998 and 2000 were very similar to the 30-year average. Therefore, the 1999 field experiment that occurred prior to the 
most intense portion of the drought and the streams surveys of 1998 and 2000 probably give the most representative picture of the relationships between macroinvertebrates and fine sediment in these streams. However, this also is the greatest limitation to this study in that only one replicate of each season (Fall 1998 and Spring 2000) and one experiment (Summer 1999) may not have been overwhelmed by the drought and revealed stream conditions, and thus, macroinvertebrate-fine sediment relationships, reflective of normal years. Therefore, conclusions regarding fine sediment from this research must be taken in light of reduced sample size and statistical power due to lost seasons and experimental replication due to the drought.

Even when drought was a strong influence, some relationships between macroinvertebrates and sediment were detected in all sample seasons. Moreover, these relationships were consistent with predicted responses to perturbation (Surber 1953; Karr and Chu 1999). This was evidence of two possible outcomes. Sediment may play an important, but secondary role to discharge in determining macroinvertebrate density and community composition. Richards and Bacon (1994) observed such a relationship where sedimentation was secondary in importance to stream size. In the case of the study streams, one can consider differences in discharge a reflection of stream size. Although these streams were selected to be very similar, it was impossible to find identical streams and small, unnoticed differences in stream size may have been important to the macroinvertebrate communities within the streams. The other outcome was sediment's effects on macroinvertebrates were independent of the role of discharge. Support for this contention was much more tenuous. While sediment was not correlated to discharge in any sample season, other 
research has indicated sediment is typically related to discharge in streams (Leopold et al. 1964; Swanston 1991). The lack of this relationship may have been indicative of sediment levels being elevated in these streams above the ambient level that would have been related to discharge. Evidence for elevated levels of fines beyond the stream's ability to transport them was observed in Elleber Run. Early in the summer of 1999, the road paralleling and crossing Elleber Run was improved with road grading and culvert replacement. The roadwork elevated sediment in the stream, but particularly in the smaller size classes (Table 1). It took the following year's spring floods to reduce sediment accumulations in the stream. A loss in macroinvertebrate diversity and decline in density was noted in Elleber Run between the fall of 1998 and fall of 1999 . Mean macroinvertebrate density declined from 2534.5 per $\mathrm{m}^{2}( \pm 1231$ SD) to 585.74 per $\mathrm{m}^{2}$ ( $\left.\pm 228.8 \mathrm{SD}\right)$. However, an unusually dry summer led to declines in all streams; although, the other streams did not experience a decline as precipitous as Elleber Run suggesting fine sediment eclipsed or exacerbated the effects of the drought. Whether sediment was the primary factor in determining macroinvertebrate density and composition or not, sediment thresholds in size and amount did occur in the streams and experiment.

\section{Implications to biomonitoring}

The clear effects of very subtle increases in sediment less than $0.25 \mathrm{~mm}$ or 0.125 $\mathrm{mm}$ upon ephemeropterans, plecopterans, and trichopterans indicates the use of the metric EPT taxa richness can be applied as a quick measure of very fine sediment accumulation within the substrate. The consistent sensitivity and reliability of this metric 
across years and seasons suggests it may be used for the detection of very fine sediment accumulation as part of a biomonitoring program. With the ease of quantitative macroinvertebrate collection, community structure analysis is a suitable substitute for extensive and costly physical habitat and water chemistry sampling (Karr and Chu 1999). Declines in EPT taxa richness do not, however, implicate sedimentation alone as a culprit, but it does provide an easier indicator than an extensive and comprehensive stream assessment. Using EPT taxa richness as an indicator, further investigation using costlier methods can be implemented only on the streams where EPT taxa richness has declined, yielding an overall savings of time and money. Of course, with the limitations arising from the drought, replication of the streams surveys and experiments on other streams during a time when other perturbations, such as drought or flooding, would corroborate the use of EPT taxa richness and, perhaps, uncover additional metrics that could be used simultaneously with EPT taxa richness to help confirm sedimentation as the source of perturbation. Further investigation is needed to test the sensitivity of the EPT taxa richness metric in other land cover types within the Appalachians and other parts of North America.

\section{Implications to forest management}

Forest management must consider the health of the entire ecosystem when making management decisions concerning forestry practices or road management. The rigorous application of BMPs has reduced sedimentation from silviculture operations themselves, but does not address road construction or the remnant road network from past operations (Furniss et al. 1991; Kochenderfer et al. 1997; Harding et al. 1998). 
Thus, in today's forest, roads are of greater concern as sediment sources than silviculture operations (Bilby et al. 1989). Road closure is unpopular and improvement is often beyond the means of forest managers (Stewart 1999). Yet, these roads are constantly influencing aquatic ecosystems through sediment delivery.

The consequence of a failure to properly manage roads is to increase sedimentation, particularly fines, into aquatic systems (Bilby et al. 1989; Constantini et al. 1999). Fines increasing within streams may exceed threshold values for impact on benthic macroinvertebrates. Recreation is a popular and ever increasing use within national forests (Clark and Gibbons 1991; Stewart 1999). Declines in macroinvertebrate densities and collapse of diversity within community structure not only are negative in the loss of the intrinsic value of the macroinvertebrates themselves, but fish and birds that rely on macroinvertebrates as food sources also may decline in areas of high sedimentation. Such declines are incompatible with today's doctrine for multiple uses of national forests.

Therefore, a monitoring, prevention, and remediation plan should be enacted within the forests to prevent or remediate situations where streams cross sedimentation thresholds. Biomonitoring programs using the EPT taxa richness metric as demonstrated by this research can quickly assess sedimentation status within a stream. Routine sedimentation sampling can incorporate the $0.9 \%$ fine sediment $(<0.25 \mathrm{~mm}$ and $0.125 \mathrm{~mm}$ ) threshold as a cutoff value. Macroinvertebrate densities and community structure were not significantly changed until sediment exceeded $0.9 \%$. Therefore, $0.9 \%$ provides the highest level tolerable with viable macroinvertebrate densities and community structure. Depending on season, samples can simply be broken into two 
groups: $0.25 \mathrm{~mm}$ and greater and less than $0.25 \mathrm{~mm}$ in the summer; or $0.125 \mathrm{~mm}$ and greater and less than $0.125 \mathrm{~mm}$ in the fall. The percentage less than $0.25 \mathrm{~mm}$ or 0.125 $\mathrm{mm}$ can be quickly determined without having to sieve through an entire sediment series. A combination of the use of the EPT taxa richness metric and routine sediment sampling can identify streams where sediment samples may need to be broken into smaller classes to determine sediment origin and asses its effects. The incorporation of the thresholds identified in this research can assist in the management of the large number of streams within the national forests of the northern Appalachians.

\section{Summary}

A sedimentation threshold occurred at approximately $1 \%$ fine $(<0.25 \mathrm{~mm}$ and $\leq 0.125 \mathrm{~mm}$ ) sediment (very fine sand in the Wentworth classification). The threshold reduced macroinvertebrate density and shifted community composition from dominance by Ephemeroptera, Plecoptera, and Trichoptera to a community with higher proportions of non-insects. Trophic processes within the streams could be interrupted with the loss of shredders, scrapers, and collectors most of whom are comprised of Ephemeroptera, Plecoptera, and Trichoptera. These taxa cannot relocate downstream; thus, loss of headwater habitat removes their contributions to trophic processing with negative consequences to the watershed. The metric EPT taxa richness is sensitive and reliable for the detection of fine sedimentation within streams with the caution that EPT taxa richness also may indicate other perturbations beside fine sediment. Fine sediment within the substrate is an important determinant of macroinvertebrate density and composition within forested Appalachian streams. 


\section{Literature Cited}

Angradi, T. R. 1999. Fine sediment and macroinvertebrate assemblages in Appalachain streams: a field experiment with biomonitoring applications. J. N. Am. Benthol. Soc. 18:43-65.

Angradi, T. R. and M. R. Vinson. 1996. Fine sediment - Aquatic macroinvertebrate relationships in headwater streams of the Monongahela National Forest: a Report to the Forest Supervisor. United States Department of Agriculture, Forest Service, Northeastern Forest Experiment Station NE-4301.

Beschta, R. L. and W. L. Jackson. 1976. The intrusion of fine sediments into a stable gravel bed. J. Fish. Res. Board. Can. 36:204-210.

Bilby, R. E., Sullivan, K., and S. H. Duncan. 1989. The generation and fate of roadsurface sediment in forested watersheds in southwestern Washington (USA). Forest Science 35:453-468.

Brunke, M. and T. Gosner. 1999. Hyporheic invertebrates - the clinal nature of interstitial communities structured by hydrological exchange and environmental gradients. J. N. Am. Benthol. Soc. 18:344-362.

Clark, R. N. and D. R. Gibbons. 1991. Recreation. American Fisheries Society Special Publication 19:459-479.

Constantini, A., Loch, R. J., Connolly, R. D., and R. Garthe. 1999. Sediment generation from forest roads: Bed and eroded sediment size distributions, and runoff management strategies. Australian Journal of Soil Research 37:947-964.

Cummins, K. W. 1962. An evaluation of some techniques for the collection and analysis of benthic samples with special emphasis on lotic waters. American Midland Naturalist 67:477-504.

Cummins, K. W. and R. W. Merritt. 1996. Ecology and distribution of aquatic insects. Pages 74-86. In An Introduction to the Aquatic Insects of North America ( $3^{\text {rd }} \mathrm{ed}$ ). Merritt, R. W. and K. W. Cummins, Eds. Kendall/Hunt Publishing Company. Dubuque, lowa.

Edmunds, G. F. and R. D. Waltz. 1996. Ephemeroptera. Pages 126-163. In An Introduction to the Aquatic Insects of North America ( $3^{\text {rd }}$ ed.) Merritt, R. W. and K. W. Cummins, Eds. Kendall/Hunt Publishing Company. Dubuque, lowa. 
Furniss, M. J., Roelefs, T. D., and C. S. Yee. 1991. Road construction and maintenance. American Fisheries Society Special Publication 19:297-323.

Grost, R.T., Hubert, W. A., and T.A. Wesche. 1991. Field comparison of three devices used to sample substrate in small streams. North American Journal of Fisheries Management 11: 347-351.

Harding, J. S., Benfield, E. F., Bolstad, P. V., Helfman, G. S., and E. B. D. Jones III. 1998. Stream biodiversity: the ghost of land use past. Proc. Nat. Acad. Sci. 95:1484314847.

Karr, J. R. and E. W. Chu. 1999. Restoring life in running waters: Better biological monitoring. Island Press. Washington, D. C.

Kochenderfer, J. N., Edwards, P. J., and F. Wood. 1997. Hydrologic impacts of logging an Appalachian watershed using West Virginia's Best Management Practices. Northern Journal of Applied Forestry 14:207-218.

Lake, P. S. 2000. Disturbance, patchiness, and diversity in streams. J. N. Am. Benthol. Soc. 19:573-592.

Lamberti, G. A. and M. Berg. 1995. Invertebrates and other benthic features as indicators of environmental change in Juday Creek, Indiana. Natural Areas Journal 15:249-258.

Leopold, L. B., Wolman, M. G., and J. P. Miller. 1964. Fluvial processes in geomorphology. Dover Publications. Mineola, New York.

McMahon, T. E., Zale, A. V., and D. J. Orth. 1996. Aquatic habitat measurements. Pages 83-115. In Fisheries Techniques, $2^{\text {nd }}$ edition. Murphy, B. R., and D. W. Willis, Eds. American Fisheries Society, Bethseda, MD.

Merritt, R. W. Resh, V. H., and K. W. Cummins. 1996. Design of aquatic insect studies: Collecting, sampling, and rearing insects. In An Introduction to the Aquatic Insects of North America ( $3^{\text {rd }}$ ed.) Merritt, R. W. and K. W. Cummins, Eds. Kendall/Hunt Publishing Company. Dubuque, lowa.

NOAA/NCDC 1999, 2000. Data provided by the National Oceanic and Atmospheric Administration's National Climate Data Center.

Richards, C. and K. L. Bacon. 1994. Influence of fine sediment on macroinvertebrate colonization of surface and hyporheic stream substrates. Great Basin Naturalist 54:106113.

Rosenberg, D. M., and A. P. Wiens. 1978. Effects of sediment addition on macroinvertebrates in a northern Canadian river. Water Research 12:753-761. 
Stewart, R. 1999. Concerning the Forest Service revised road policy. Statement of Ron Stewart, Deputy Chief, Forest Service, United States Department of Agriculture, before the Subcommittee on Forests and Forest Health, Committee on Resources, United States House of Representatives, March 4, 1999.

Surber, E. W. 1953. Biological effects of pollution in Michigan waters. Sewage and Industrial Wastes 25:79-86.

Swanston, D. N. 1991. Natural processes. American Fisheries Society Special Publication 19:139-179.

Tebo, L. B. 1955. Effect of siltation, resulting from improper logging, on bottom fauna of a small trout stream in the Appalachains. Progressive Fish-Culturist 17:64-70.

Vannote, R. L., Minshall, G. W., Cummins, K. W., Sedell, J.R., and C. E. Cushing. 1980. The river continuum concept. Can. J. Fish. Aquat. Sci. 45:1123-1144.

Thorp, J. H. and A. P. Covich. 1991. An overview of freshwater habitats. Pages 17-36. In Ecology and Classification of North American Freshwater Invertebrates. Thorp, J. H. and A. P. Covich, Eds. Academic Press, Inc. San Diego, California.

Vouri, K. and I. Joensuu. 1996. Impact of forest drainage on the macroinvertebrates of a small boreal headwater stream: Do buffer zones protect lotic biodiversity? Biological Conservation 77:87-95.

Waters, T. F. 1995. Sediment in streams: sources, biological effects, and control. American Fisheries Society Monograph 7. American Fisheries Society. Bethseda, Maryland. 
Table 1. Changes in substrate composition in Elleber Run from 1999-2000.

\begin{tabular}{lcccccccc}
\hline Collection & $\%<8 \mathrm{~mm}$ & $\%<4 \mathrm{~mm}$ & $\%<2 \mathrm{~mm}$ & $\%<1 \mathrm{~mm}$ & $\%<0.5 \mathrm{~mm}$ & $\%<0.25 \mathrm{~mm}$ & $\%<0.125 \mathrm{~mm}$ & $\%<0.063 \mathrm{~mm}$ \\
\hline Spring 1999 & 11.2 & 6.2 & 4.4 & 3.2 & 1.8 & 0.7 & 0.7 & 0.1 \\
Fall 1999 & 27.1 & 16.6 & 8.1 & 4.5 & 3.1 & 1.7 & 4.2 & 0.2 \\
Spring 2000 & 11.5 & 7.1 & 3.0 & 1.6 & 1.0 & 0.6 & 2.6 & 0.1 \\
\hline
\end{tabular}


Appendix 1. Taxonomic record of macroinvertebrates collected over the course of this study from 7 streams in the Monongahela National Forest.

\begin{tabular}{|c|c|c|c|c|c|c|c|c|}
\hline Order & Family Genus & Elleber Run & Lick Run & Little Low Place & Long Run & Mullenax Run & Poca Run & Sawmill Run \\
\hline Amphipoda & Gammaridae & $x$ & & $\mathrm{x}$ & $\mathrm{x}$ & & $\mathrm{x}$ & $\mathrm{x}$ \\
\hline Aranea & & & $x$ & $\mathrm{x}$ & $x$ & $\mathrm{x}$ & & $\mathrm{x}$ \\
\hline \multirow[t]{5}{*}{ Coleoptera } & Curculionidae & $\mathrm{x}$ & & & & & & \\
\hline & Dytiscidae & $\mathrm{x}$ & & & $\mathrm{x}$ & & $\mathrm{x}$ & \\
\hline & Elmidae & $x$ & $x$ & $\mathrm{x}$ & $x$ & $x$ & $\mathrm{x}$ & $\mathrm{x}$ \\
\hline & Hydrophilidae & $\mathrm{x}$ & $\mathrm{x}$ & $x$ & $\mathrm{x}$ & $\mathrm{x}$ & $\mathrm{x}$ & $x$ \\
\hline & Psephenidae & & & & $x$ & $x$ & & $x$ \\
\hline Copepoda & & & $\mathrm{x}$ & & $\mathrm{x}$ & & $\mathrm{x}$ & \\
\hline Decapoda & & $x$ & $\mathrm{x}$ & $x$ & $\mathrm{x}$ & $\mathrm{x}$ & $\mathrm{x}$ & $x$ \\
\hline \multirow[t]{11}{*}{ Diptera } & Athericidae & & & & & & & \\
\hline & Atherix spp. & $\mathrm{x}$ & $x$ & $x$ & $\mathrm{x}$ & $\mathrm{x}$ & $\mathrm{x}$ & $\mathrm{x}$ \\
\hline & Blephariceridae & $\mathrm{x}$ & & & & $x$ & & \\
\hline & Ceratopogonidae & $x$ & $x$ & $\mathrm{x}$ & $\mathrm{x}$ & $\mathrm{x}$ & $x$ & $\mathrm{x}$ \\
\hline & Chironomidae & $\mathrm{x}$ & $\mathrm{x}$ & $\mathrm{x}$ & $\mathrm{x}$ & $\mathrm{x}$ & $\mathrm{x}$ & $\mathrm{x}$ \\
\hline & Dixidae & & & & & & & \\
\hline & Dixella spp. & & & $\mathrm{x}$ & & & & $\mathrm{x}$ \\
\hline & Empididae & $x$ & & & $\mathrm{x}$ & $\mathrm{x}$ & & \\
\hline & Simuliidae & $x$ & $\mathrm{x}$ & $\mathrm{x}$ & $\mathrm{x}$ & $\mathrm{x}$ & $\mathrm{x}$ & $\mathrm{x}$ \\
\hline & Tabanidae & $\mathrm{x}$ & $\mathrm{x}$ & & & $\mathrm{x}$ & $\mathrm{x}$ & $\mathrm{x}$ \\
\hline & Tipulidae & $x$ & $x$ & $\mathrm{x}$ & $\mathrm{x}$ & $\mathrm{x}$ & $x$ & $\mathrm{x}$ \\
\hline
\end{tabular}


Appendix 1 continued. Taxonomic record of macroinvertebrates collected over the course of this study from 7 streams in the Monongahela National Forest.

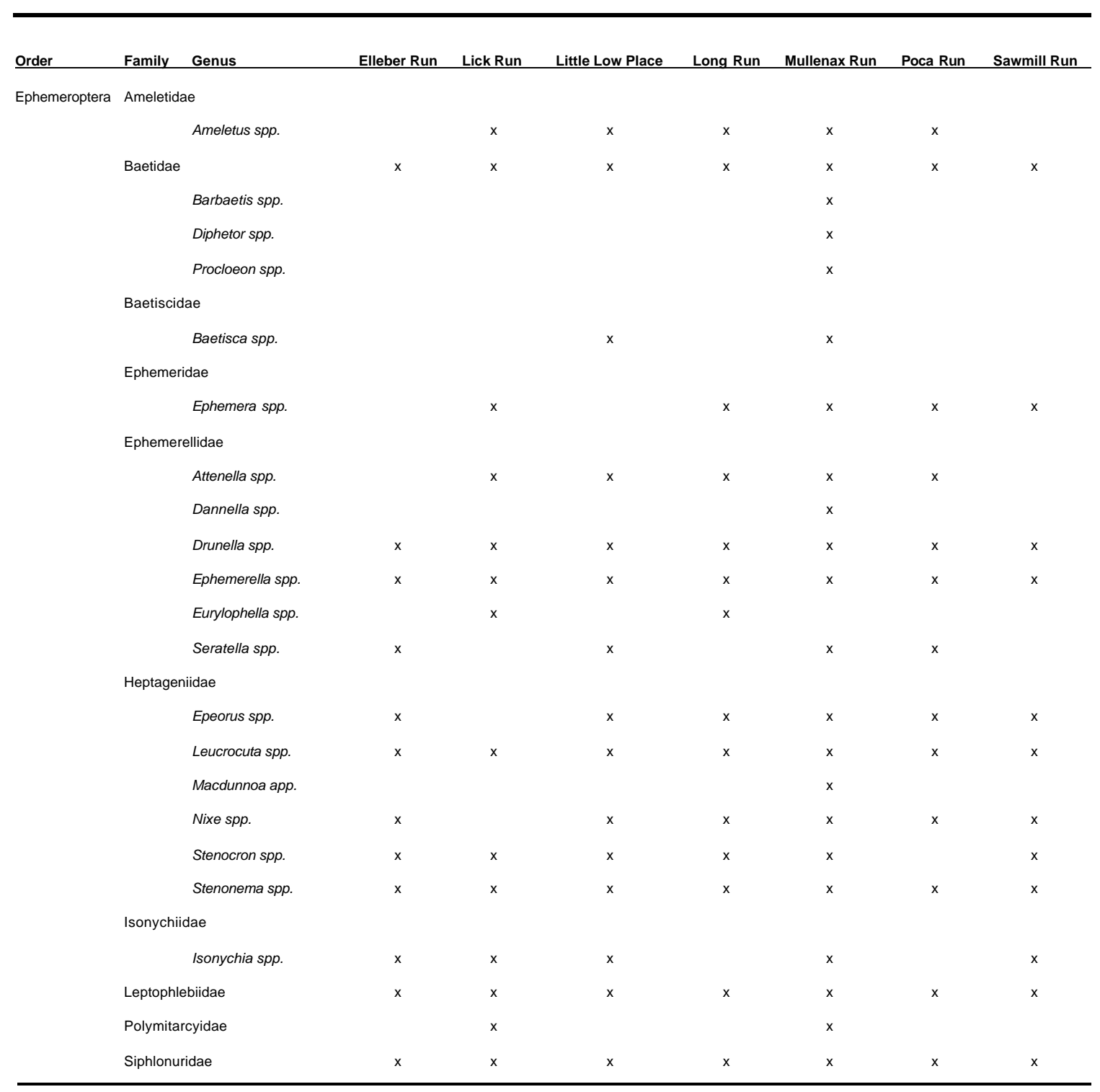


Appendix 1 continued. Taxonomic record of macroinvertebrates collected over the course of this study from 7 streams in the Monongahela National Forest.

\begin{tabular}{|c|c|c|c|c|c|c|c|c|c|}
\hline Order & Family & Genus & Elleber Run & Lick Run & Little Low Place & Long Run & Mullenax Run & Poca Run & Sawmill Run \\
\hline \multirow[t]{5}{*}{ Hemiptera } & Gerrida & & & & & & $\mathrm{x}$ & & \\
\hline & Macrov & iidae & & & & & $\mathrm{x}$ & & \\
\hline & Pleidae & & & & & & $x$ & & \\
\hline & Saldida & & & & & & $\mathrm{x}$ & & \\
\hline & Veliidae & & $x$ & & & & $x$ & & \\
\hline Hirudinea & & & $\mathrm{x}$ & $\mathrm{x}$ & & & $\mathrm{x}$ & & \\
\hline Hydracarina & & & $\mathrm{x}$ & $\mathrm{x}$ & & $\mathrm{x}$ & $x$ & & $\mathrm{x}$ \\
\hline Hymenoptera & Formici & & & & & & & & \\
\hline Isopoda & Spaeror & atidae & & & & & $\mathrm{x}$ & & \\
\hline \multirow[t]{2}{*}{ Lepidoptera } & Cossidz & & & & & & $x$ & & \\
\hline & Nepticu & & & & & & $x$ & & \\
\hline \multirow[t]{4}{*}{ Megaloptera } & Coryda & & & & & & & & \\
\hline & & Corydalus spp. & & $z$ & & & $z$ & & $\mathrm{x}$ \\
\hline & Sialidae & & & & & & & & \\
\hline & & Sialis spp. & $z$ & $\mathrm{x}$ & & & $\mathrm{x}$ & $z$ & \\
\hline Nematomorpha & & & $\mathrm{x}$ & $\mathrm{x}$ & $\mathrm{x}$ & $x$ & $\mathrm{x}$ & $\mathrm{x}$ & $\mathrm{x}$ \\
\hline \multirow[t]{8}{*}{ Odonata } & Aeshnic & & & & & & & & \\
\hline & & Boyeria spp. & & $\mathrm{x}$ & & & $x$ & $x$ & \\
\hline & Coenag & onidae & & & & & & & \\
\hline & & Enallgma spp. & & $x$ & & & & & \\
\hline & Cordule & asteridae & & & & & & & \\
\hline & & Cordulegaster spp. & & $\mathrm{x}$ & & & $x$ & & \\
\hline & Gomph & & & & & & & & \\
\hline & & Arigomphus spp. & $\mathrm{x}$ & $x$ & $\mathrm{x}$ & $x$ & $\mathrm{x}$ & $\mathrm{x}$ & $\mathrm{x}$ \\
\hline
\end{tabular}


Appendix 1 continued. Taxonomic record of macroinvertebrates collected over the course of this study from 7 streams in the Monongahela National Forest.

\begin{tabular}{|c|c|c|c|c|c|c|c|c|c|}
\hline Order & Family & Genus & Elleber Run & Lick Run & Little Low Place & Long Run & Mullenax Run & Poca Run & Sawmill Run \\
\hline Oligochaeta & & & $\mathrm{x}$ & $x$ & $x$ & $x$ & $x$ & $\mathrm{x}$ & $x$ \\
\hline \multirow[t]{25}{*}{ Plecoptera } & \multicolumn{2}{|c|}{ Capniidae } & & $x$ & & $\mathrm{x}$ & & $\mathrm{x}$ & $\mathrm{x}$ \\
\hline & \multicolumn{2}{|c|}{ Chloroperlidae } & $x$ & $\mathrm{x}$ & $\mathrm{x}$ & $\mathrm{x}$ & $\mathrm{x}$ & $\mathrm{x}$ & $\mathrm{x}$ \\
\hline & \multicolumn{2}{|c|}{ Leucritidae } & $\mathrm{x}$ & $x$ & $x$ & $\mathrm{x}$ & $x$ & $x$ & $x$ \\
\hline & \multicolumn{2}{|c|}{ Nemouridae } & $\mathrm{x}$ & $x$ & $\mathrm{x}$ & $\mathrm{x}$ & $x$ & $x$ & $x$ \\
\hline & \multicolumn{9}{|c|}{ Peltoperlidae } \\
\hline & & Tallaperla spp. & $\mathrm{x}$ & $x$ & $\mathrm{x}$ & $\mathrm{x}$ & $x$ & $x$ & $x$ \\
\hline & \multicolumn{2}{|c|}{ Perlidae } & $x$ & $x$ & $x$ & $\mathrm{x}$ & $\mathrm{x}$ & $x$ & $\mathrm{x}$ \\
\hline & & Acroneuria spp. & $\mathrm{x}$ & $\mathrm{x}$ & $\mathrm{x}$ & $\mathrm{x}$ & $\mathrm{x}$ & & \\
\hline & & Agnetina spp. & & $\mathrm{x}$ & & & $x$ & & $x$ \\
\hline & & Beloneuria spp. & $\mathrm{x}$ & & & & & & $\mathrm{x}$ \\
\hline & & Claasenia spp. & & & & & & & $\mathrm{x}$ \\
\hline & & Eccoptura spp. & & & & & $x$ & & \\
\hline & & Hansonoperla spp. & & & & & $\mathrm{x}$ & & \\
\hline & & Neoperla spp. & & & & & $\mathrm{x}$ & & \\
\hline & & Paragnetina spp. & $x$ & & & & & & $x$ \\
\hline & & Perlesta spp. & & & & & $\mathrm{x}$ & & \\
\hline & & Perlinella spp. & & & $\mathrm{x}$ & & $\mathrm{x}$ & & \\
\hline & \multicolumn{2}{|c|}{ Perlodidae } & $\mathrm{x}$ & $\mathrm{x}$ & $\mathrm{x}$ & $\mathrm{x}$ & $x$ & $\mathrm{x}$ & $\mathrm{x}$ \\
\hline & & Cultus spp. & $\mathrm{x}$ & & & & & & \\
\hline & & Diura spp. & & $\mathrm{x}$ & & & & & \\
\hline & & Hydroperla spp. & $x$ & & & & & & \\
\hline & & Isoperla spp. & $x$ & $\mathrm{x}$ & $x$ & $x$ & & $x$ & \\
\hline & & Yugus spp. & $\mathrm{x}$ & $x$ & $x$ & $x$ & $x$ & $x$ & \\
\hline & Pterona & zyidae & $\mathrm{x}$ & $\mathrm{x}$ & $\mathrm{x}$ & $x$ & & $\mathrm{x}$ & $x$ \\
\hline & Taenio & erygidae & $\mathrm{x}$ & $\mathrm{x}$ & $\mathrm{x}$ & $\mathrm{x}$ & $\mathrm{x}$ & $\mathrm{x}$ & $\mathrm{x}$ \\
\hline Trichoptera & Brachy & ntridae & & & & & $\mathrm{x}$ & & \\
\hline
\end{tabular}


Appendix 1 continued. Taxonomic record of macroinvertebrates collected over the course of this study from 7 streams in the Monongahela National Forest.

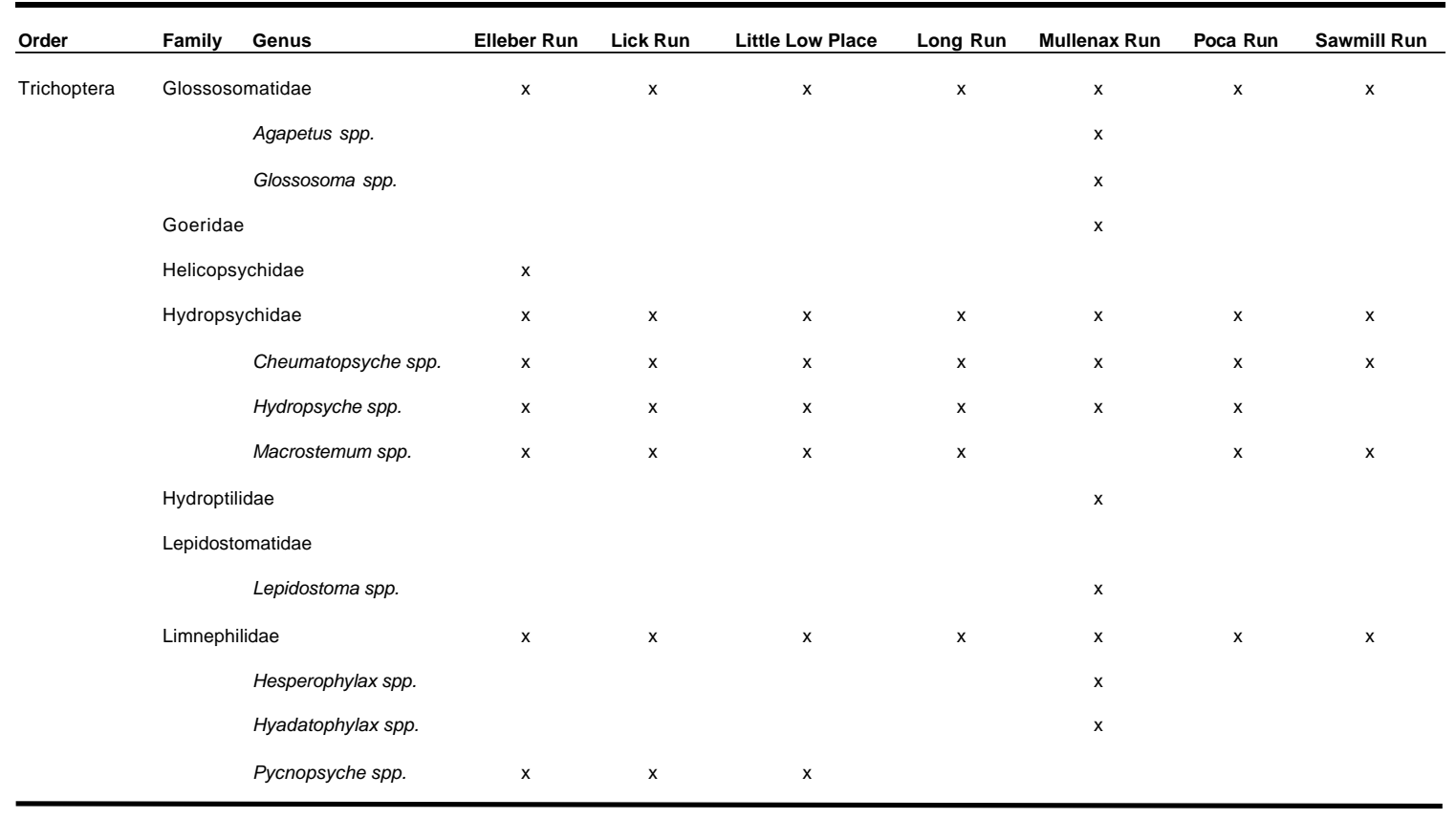


Appendix 1 continued. Taxonomic record of macroinvertebrates collected over the course of this study from 7 streams in the Monongahela National Forest.

\begin{tabular}{|c|c|c|c|c|c|c|c|c|}
\hline Order & Family Genus & Elleber Run & Lick Run & Little Low Place & Long Run & Mullenax Run & Poca Run & Sawmill Run \\
\hline \multirow{15}{*}{ Trichoptera } & Odontoceridae & & & & & & & \\
\hline & Psilotreta spp. & & & & & $x$ & & \\
\hline & Philopotamidae & $\mathrm{x}$ & $x$ & $\mathrm{x}$ & $\mathrm{x}$ & $x$ & $\mathrm{x}$ & $\mathrm{x}$ \\
\hline & Chimarra spp. & & & & & & & \\
\hline & Dolophilodes spp. & $x$ & & $\mathrm{x}$ & $x$ & & & \\
\hline & Wormaldia spp. & $x$ & $x$ & & $\mathrm{x}$ & $x$ & & $x$ \\
\hline & Polycentropodidae & $\mathrm{x}$ & $\mathrm{x}$ & $\mathrm{x}$ & $\mathrm{x}$ & $x$ & $x$ & $\mathrm{x}$ \\
\hline & Polycentropus spp. & & & & & $x$ & & \\
\hline & Phryganeidae & & & & & $x$ & & \\
\hline & Psychomyiidae & & $\mathrm{x}$ & $\mathrm{x}$ & $\mathrm{x}$ & $x$ & & \\
\hline & Lype spp. & & & & & $x$ & & \\
\hline & Rhyacophilidae & $\mathrm{x}$ & $x$ & $x$ & $x$ & $\mathrm{x}$ & $\mathrm{x}$ & $x$ \\
\hline & Rhyacophia spp. & & & & & $x$ & & \\
\hline & Uenoidae & $x$ & & $\mathrm{x}$ & $\mathrm{x}$ & $x$ & $x$ & \\
\hline & Neophylax spp. & & & & & $x$ & & \\
\hline
\end{tabular}




\section{Michael Douglas Kaller \\ 26 Woodside Park Blvd. \\ Pleasant Ridge, MI \\ 48069 \\ (248)542-1360 (P) \\ Division of Forestry \\ West Virginia University \\ Box 6125 \\ 322 Percival Hall \\ Morgantown, WV 26505 \\ (304)293-2941 ext. 2315 (W) \\ (304)598-0282 (H) \\ mkaller@wvu.edu}

\section{E D U C A T ION}

West Virginia University

Morgantown, WV

M.S. Wildlife and Fisheries Resources
August 1998 - May 2001

Thesis title: Effects of sedimentation upon benthic macroinvertebrates in forested northern Appalachian streams.

Major professor: Kyle J. Hartman

Overall G.P.A. : 3.87

Relevant courses: Fisheries Management, Fisheries Ecology, Quantitative Ecology, Wetland Ecology and Management

\section{Lake Superior State University}

August 1993- May 1997

Sault Ste. Marie, MI

B.S. Fisheries and Wildlife Management, Cum laude

Minor: Chemistry

Senior thesis: Validation of aging techniques for walleyes (tizostedion vitreum) from Munuscong Bay, MI.

Overall G.P.A: 3.539

Relevant Courses: Biometrics, Ichthyology, Introduction to GIS, Freshwater Fish Culture, Fish Ecology and Management, Limnology, Plant Ecology. 


\section{W O R K E X P E R I E N C E}

\section{Research Aide}

Division of Forestry

West Virginia University

Morgantown, WV.

Identified macroinvertebrate samples from ongoing projects monitoring the impacts of large woody debris additions to headwater streams.

Supervisor: Kyle J. Hartman, Ph.D.

Phone: (304)293-2941 ext. 2494

\section{Graduate Research Assistant \\ Division of Forestry \\ West Virginia University}

Morgantown, WV.

Conducted field and lab research pertinent to thesis.

Backpack electroshocking headwater streams and small rivers.

Collected fish for contaminant analysis.

Water quality analyses with YSI, Hydrolab, and HACH equipment.

Co-authoring manuscript concerning downstream effects of valley fill mining with Kyle J. Hartman and John W. Howell.

Conducted a mountain top removal mining biomonitoring assessment with Kyle J.

Hartman and John W. Howell.

Supervisor: Kyle J. Hartman, Ph.D.

Phone: (304)293-2941 ext. 2494

\section{Biologist Technician}

Wyoming Game and Fish Department

Pinedale, WY

Creel clerk for fishery evaluation of the finger lakes (Boulder, Willow, and New Fork Lakes).

Creel clerk for fishery evaluation of the upper Green River.

Backpack and raft electrofishing crew member

Gill netting crew member.

Purse seining survey of Boulder Lake.

Supervisor: David Belford

Phone: (307)367-4352 


\title{
Student Worker
}

\section{LSSU Aquatic Research Lab}

May 1996-August 1996

Sault Ste. Marie, MI

Hatchery culture of Atlantic salmon, Chinook salmon, and rainbow trout from egg

collection to stocking.

Chemical disease treatment of fish

Sea lamprey assessment and sex determination for USFWS

Supervisor: Roger Greil

Phone: (906)635-1949

\section{TEACHING EXPERIENCE}

\author{
Graduate Teaching Assistant \\ General Biology 3 and 4 \\ August 1999 - May 2000 \\ West Virginia University \\ August 1998 - May 1999 \\ Morgantown, WV. \\ Instructor and lecturer for 4 weekly general biology labs. \\ Responsible for design of and grading lectures, quizzes, and lab reports.
}

Supervisor: Joseph A. Marshall, Ph.D.

Phone: (304)293-5201

\section{PR E S E N T A T IO N S}

Kaller, M. D. and K. J. Hartman. 2000. Effects of sedimentation on benthic macroinvertebrates in forested northern Appalachian streams. Oral presentation at the Annual meeting of the American Fisheries Society (August 24, 2000.)

Kaller, M. D. and K. J. Hartman. 2000. The effects of sedimentation upon benthic macroinvertebrates in forested northern Appalachian streams. Poster presentation at the Annual meeting of the North American Benthological Society. (May 31, 2000).

Kaller, M. D. and K. J. Hartman. 2000. Effects of sedimentation on benthic macroinvertebrates in forested northern Appalachian streams. Oral presentation at the Annual meeting of the Northeast Fish and Wildlife Conference. (April 9, 2000)

Kaller, M. D. and K. J. Hartman. 2000. Effects of sedimentation on benthic macroinvertebrates in forested northern Appalachian streams. Oral presentation at the $49^{\text {th }}$ annual Tri-State Fisheries meeting. (Mar. 8, 2000)

Kaller, M. D. and K. J. Hartman. 1999. Effects of sedimentation and large woody debris on benthic macroinvertebrates in forested Appalachian streams. Oral presentation at the WESTVACO Forest Meeting. (January 14, 1999) 
Kaller, M. D. and T. M. Sutton. 1997. Evaluation of techniques used o determine age structure of walleyes (Stizostedion Vitreum) in Munuscong Bay, MI. Oral presentation at the Michigan Chapter American Fisheries Society Spring meeting. (Mar. 7, 1997)

\section{R ELEVAN T COURSE W O R K}

Biometrics: (LSSU) This undergraduate course introduced a variety of statistical tests to analyze biological data. This course applied tests to common ecological questions.

Fish Ecology and Management: (LSSU) This undergraduate course introduced topics involving trophic dynamics, bioenergetics, population modeling, stream management, reproductive ecology, and human dimensions. Intensive lab activities in fish and macroinvertebrate sampling techniques were included.

Fish Ecology: (WVU) This graduate course elaborated in depth the topics of bioenergetics, modeling, trophic ecology, invader ecology, and reproductive ecology.

Fish Management: (WVU) This graduate/undergraduate course covered topics of population modeling, applying models to management, habitat assessment and management.

Freshwater Fish Culture: (LSSU) This undergraduate course introduced topics relevant to hatchery construction and management. Pond, raceway, and net culture were all covered.

Ichthyology: (LSSU) This undergraduate course covered taxonomy, anatomy, physiology, and reproductive biology of marine and freshwater fish.

Introduction to GIS: (LSSU) This undergraduate course introduced GIS concepts and provided software to learn raster and vector mapping, digitizing, layering, and querying.

Limnology: (LSSU) This undergraduate course dealt with physical, chemical, and biological limnology. Top-down and bottom-up trophic mechanisms as well as introductions were extensively covered.

Plant Ecology: (LSSU) This undergraduate course primarily covered wildlife and plant interactions. However, it did spend a substantial amount of time on watershed management for aquatic resources.

Quantitative Ecology: (WVU) This graduate course covered in depth statistical techniques for analyzing biological data. Software packages for statistical analysis 
(NTSYS, Kreb's Ecological Models, and SAS) were introduced and applied to ecological questions.

Wetland Ecology and Management: (WVU) This graduate course primarily covered wetland construction, management for wildlife, delineation, and policy. However, the course did address wetland use as spawning and rearing habitat for fish and invertebrates.

\section{A B E XPERIENCES}

Aquatic invertebrate sampling with plankton nets and kick nets, beach seining, hoop and fyke netting, passerine and raptor banding, water quality testing, plankton sampling and identification, digitizing, TNT MIPS GIS software.

\section{O L U N TEER EXPER IENCES}

Trapping to monitor Allegheny Woodrat dispersal (Apr. 2000)

3 time guest lecturer for WVU Fisheries Techniques class (Mar. 2000)

Ohio river lock rotenone (Sept. 1998)

Creel survey for Newberry district, Michigan DNR (spring1996 and spring1997)

\section{PROFESSIONAL MEMBERS H P S}

American Fisheries Society (1995-present)

North American Benthological Society (1999-present)

Treasurer, WVU Division of Forestry Graduate Student Association (1999-2000)

Historian, WVU Wildlife Society (1999-2000)

Secretary, LSSU Fish and Wildlife Club (1996-1997)

\section{A W A R D S RECEIVED}

Best student paper - Kaller, M. D. and K. J. Hartman. 2000. Effects of sedimentation on benthic macroinvertebrates in forested northern Appalachian streams. Presented at the $49^{\text {th }}$ annual Tri-State Fisheries meeting. (Mar. 8, 2000)

West Virginia University Dean's List (1998-2000)

Lake Superior State University Board of Regents Distinguished Scholarship (19931997)

Lake Superior State University Dean's List (1993, 1995-1997)

National Merit Semi-finalist (1993)

National Honor Society (1991-1993) 


\section{R E L E V A N T S K I L L S}

CPR and First Aid certified

Macroinvertebrate sampling with Surber, kick, core, and Hess type samplers

Macroinvertebrate identification to genus

Sediment sampling and analysis

Extensive working knowledge of SAS, MS Excel, MS Word, and MS Powerpoint

Backpack, raft, and parallel wire electrofishing

Hoop, gill, and fyke netting

US Forest service S-130/S-190 and ICS

Sea Lamprey sex determination

Aging fish with scales, dorsal spine cross-sections, and otoliths

Basic GIS construction

Basic fish hatchery management

Small watercraft operation

Basic carpentry and plumbing 


\section{R E F E R E N C E S}

TED R. AngRadi, Ph.D.

AQUATIC ECOLOGIST

UNITED STATES ENVIRONMENTAL PROTECTION A GENCY

PHONE: (303)312-6575

ANGRADI.THEODORE@EPAMAIL.EPA.GOV

KYLE J. HARTMAN, PH.D.

ASSISTANT PROFESSOR

WEST VIRGINIA UNIVERSITY

PHONE:(304)293-2941 EXT. 2494

HARTMAN@WVU.EDU

Joseph A. MARShall, Ph.D.

ASSOCIATE PROFESSOR

WEST VIRGINIA UNIVERSITY

PHONE: (304)293-5201

JMAR@WVNVM.WVNETEDU

PATRICIA M. MAZIK, PH. D.

UNIT LEADER

WEST VIRGINIA COOPERATIVE FISH AND WILDLIFE UNIT

PHONE:

PMAZIK@WVU.EDU

Greg Zimmerman, Ph.D.

ASSISTANT PROFESSOR

LAKE SUPERIOR STATE UNIVERSITY

PHONE:(906)635-2470

GZIMMERMAN@GW.LSSU.EDU 